\section{Journal of Home Economics}

http://homeEcon.menofia.edu.eg
مجلة الاقتصاد المنزلي

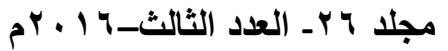

ISSN 1110-2578

\title{
إثراء القيمة الوظيفية والجمالية لملابس السهرة الحريمي بإستخدام أقمشة الجينز المخلوطة بالليكرا
}

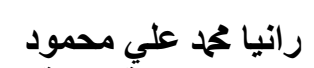

مدرس بقسم الاقتصاد المنزلي،كلية التربية النوعية،جامعة بنها

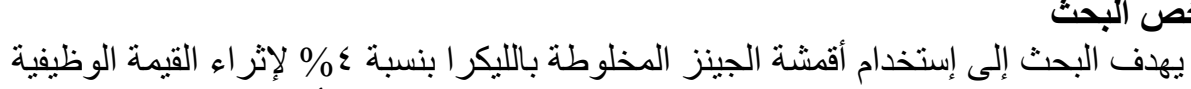

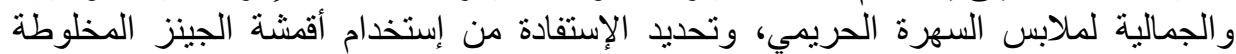

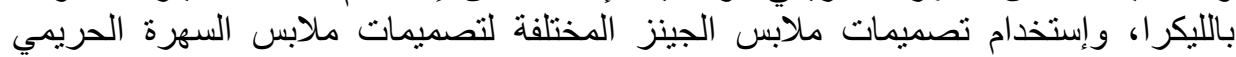

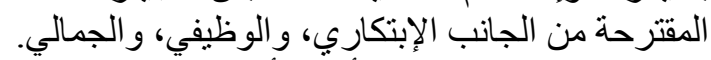

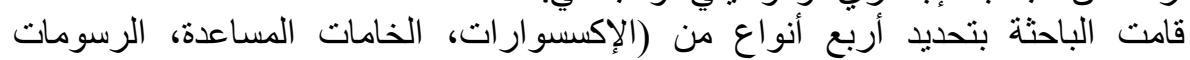

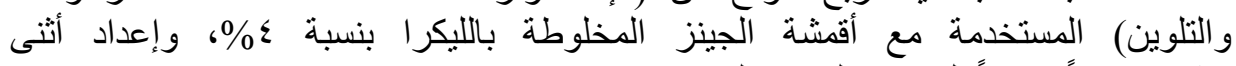
عشرتصميماًمقترحاً لملابس السهرة الحمرة الحريمي.

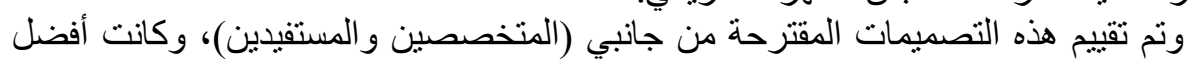

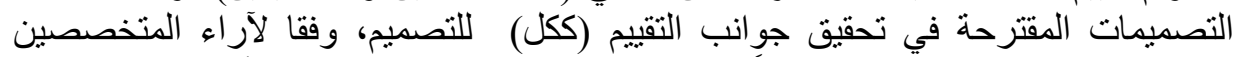

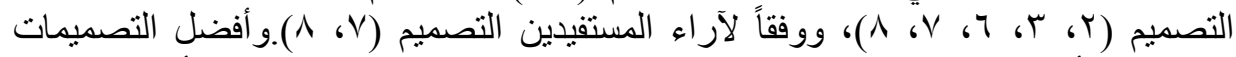

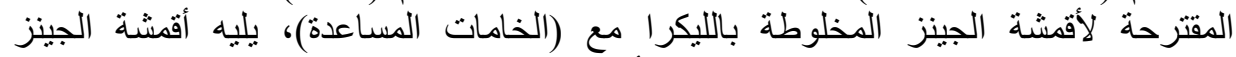

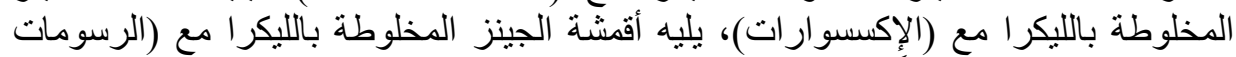

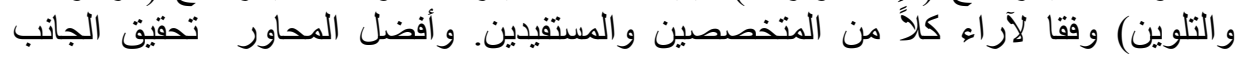

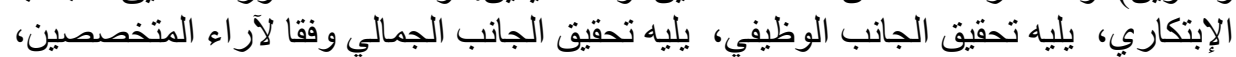

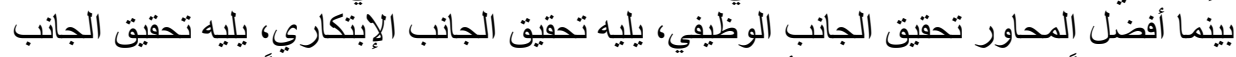

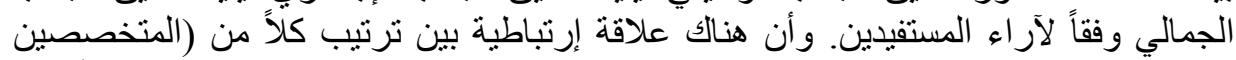

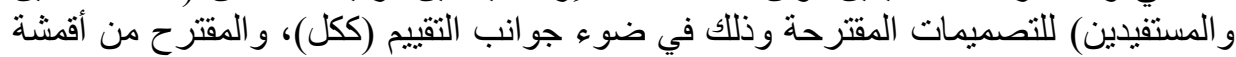

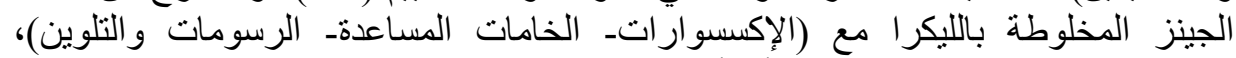

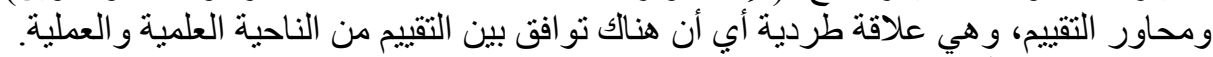

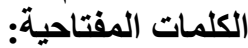

القيمة الوظيفية ـ القيمة الجمالية ــلابس السهرة الحريميـ الجينز ـ الجينز المخلوط بالليكر ا. المقدمة والمشكلة البحثية:

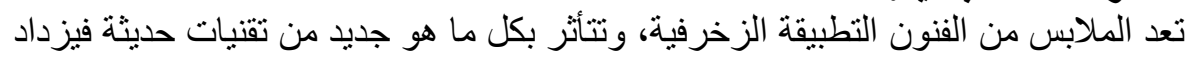

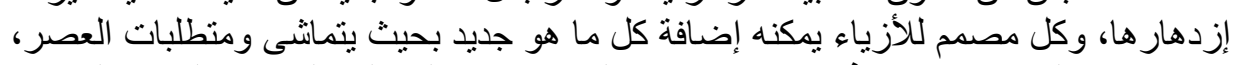

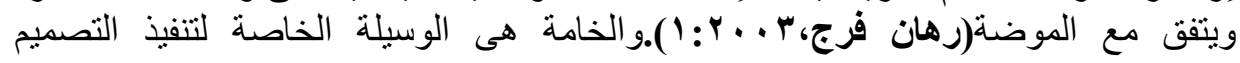




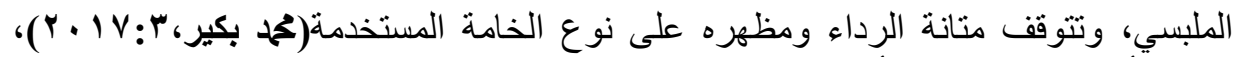

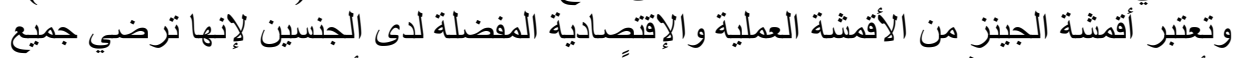

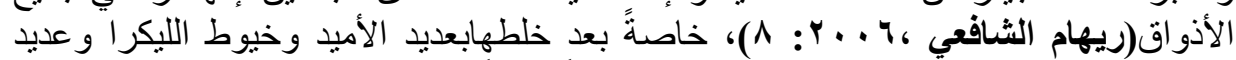

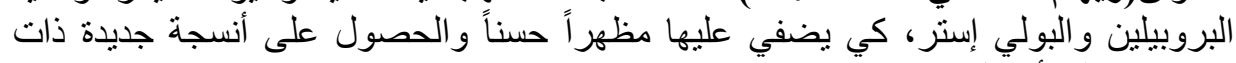

صفات جمالية أفضل (A Edwin Sunder, etal, 2002: 53).

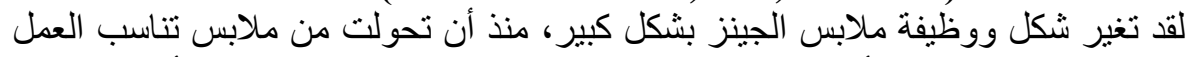

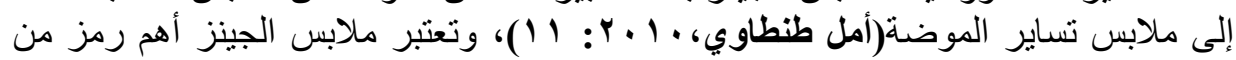

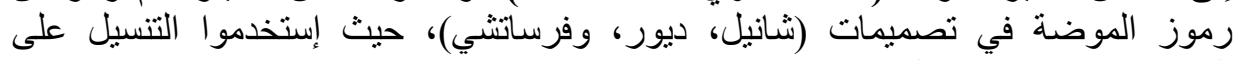

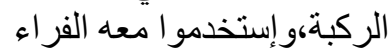
.https:// www.Designboom.com/eng/education/denim2.html) وملابس الجينز من أهم المنتجات التي تلقى رواجاً في السوق العالمي، فهى من الملابس شائعة

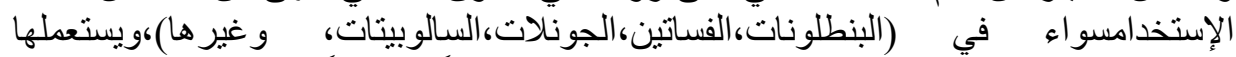

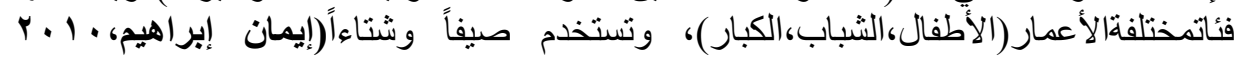

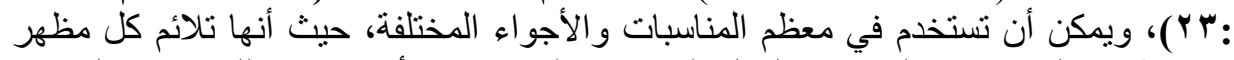

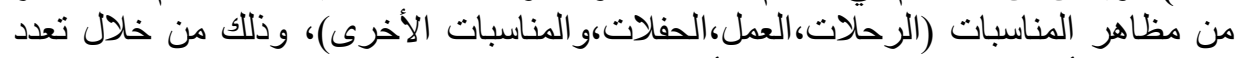

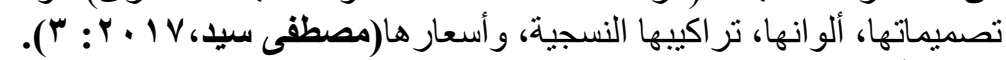

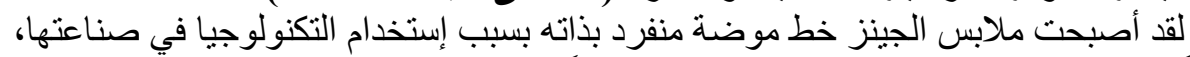

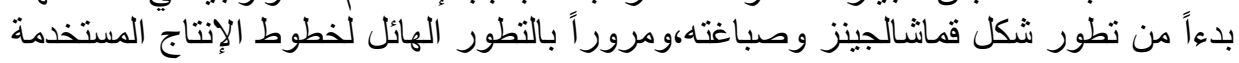

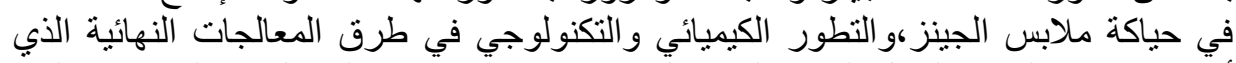

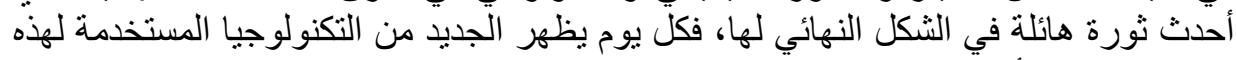

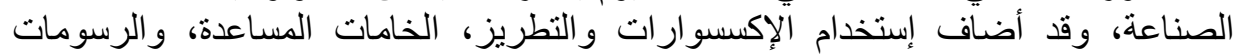

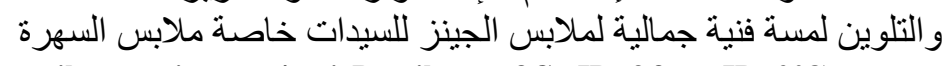
https://www.egyptiantextilemagazine.com/topicDetails.aspx?CatID=3\&top ID=208).

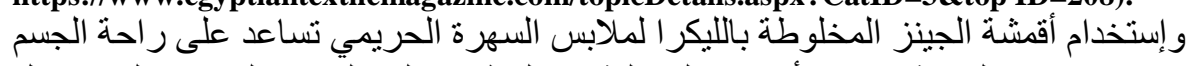

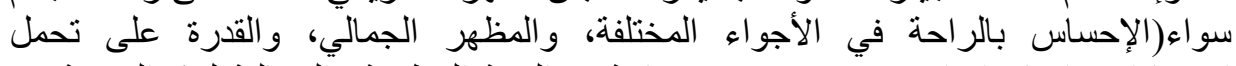

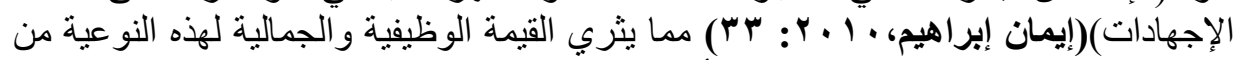

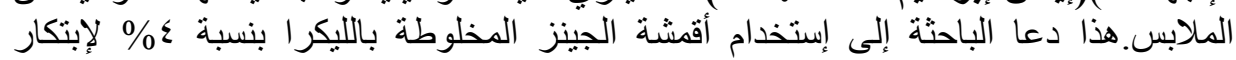

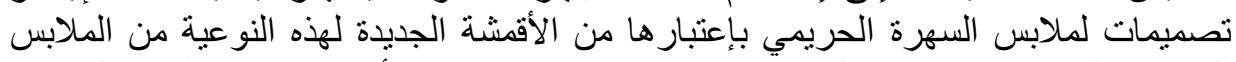

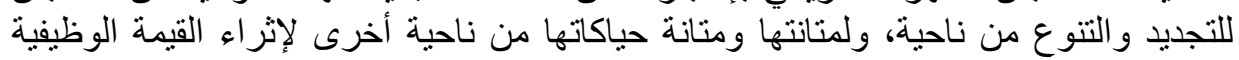
و الجمالية لها.

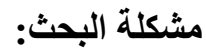

تتمثل مشكلة البحث في التساؤل البرائيسي الآتي:

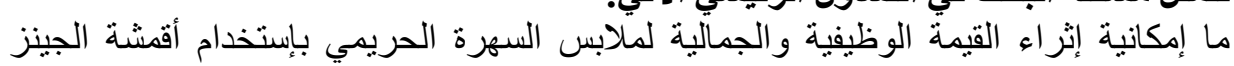

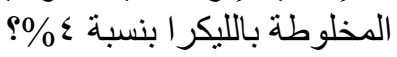

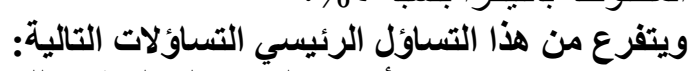

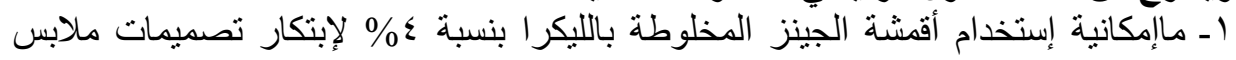
السهرة الحريمي؟ إنئج 
r- ماإمكانية الإستفادة من تصميمات ملابس الجينز المختلفة في إبتكار تصميمات ملابس

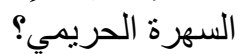
بـ ما إمكانية إثراء القيمة الوظيفية والجمالية لملابس السهرة الحريمييإستخدام أقمشة الجينز

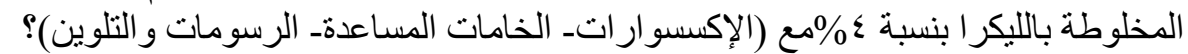

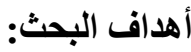

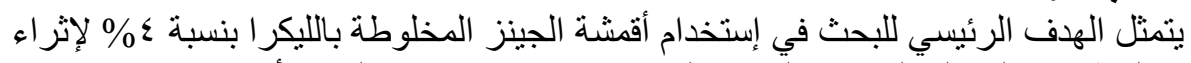

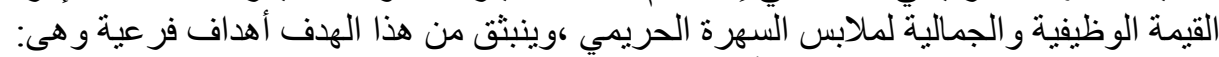

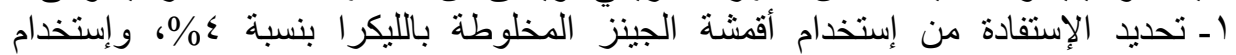
تصميمات ملابس الجينز المختلفة لتصميمات ملابس السهرة الحئزة الحريميالمقترحة من الجانب

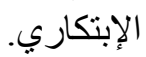

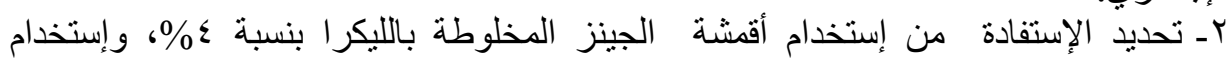
تصميمات ملابس الجينز المختلفة لتصميمات ملابس السهرة الحريمي المقترحة من الجانب والبكات

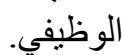

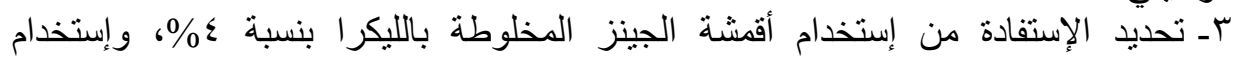
تصميمات ملابس الجينز المختلفة لتصميمات ملابس السهرة الحريمي المقترحة من الجانب

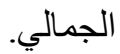

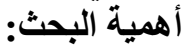
إن إستخدام أقششة الجينز المخلوطة بالليكر ا بنسبة ؛ \%ة، و إستخدام تصميمات ملابس الجينز

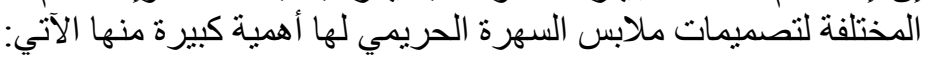
ا ـ تساعدتصميمات ملابس الجينز المختلفة على التجديد والتهيرة التنوع لتصميمات ملابس السهرة

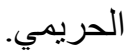
r ـ تساعدتصميمات ملابس الجينز المختلفة على إبتكار تصميماتجديدةلملابس السهرة الحريمي.

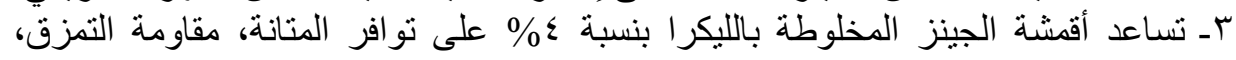

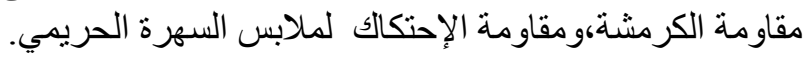
عـ تساعد خيوط حياكات ملابس الجينز المختلفة الفئة على تو افر متانة الحياكات لملابس السهرة

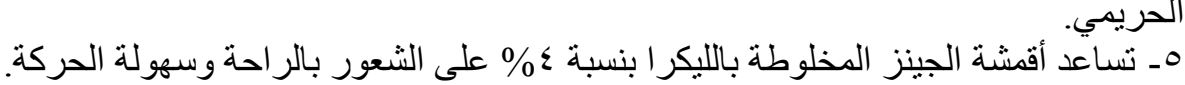

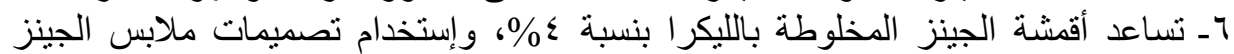
المختلفة على حسن المظهرية لتصميمات ملابس السهرة البكرة الحريمي.

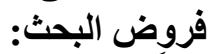

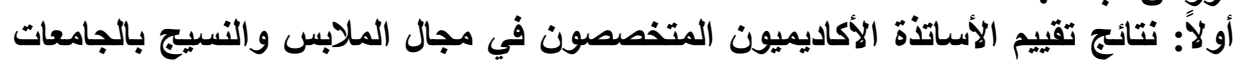

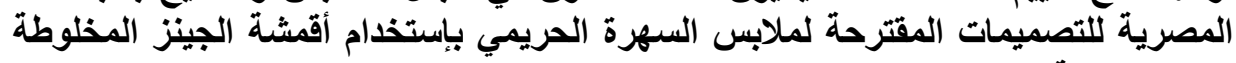

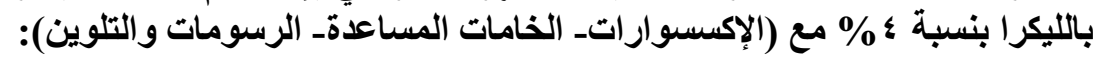

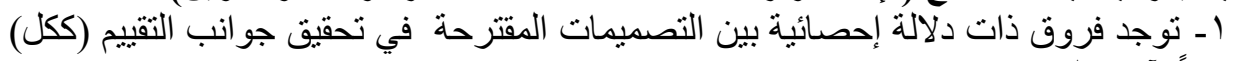




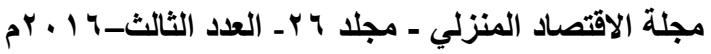

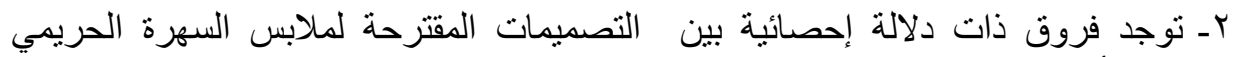

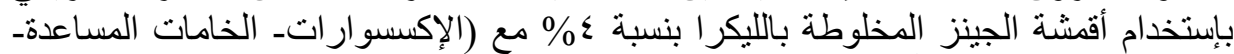

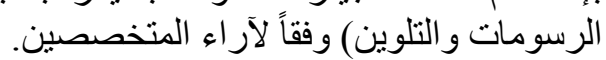
r- توجد فروق ذات دلالة إحصائية بين محاور تقييم التصميمات المقترحة وفقاً لآراء

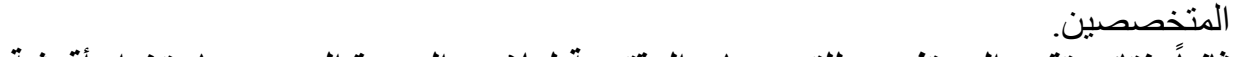
ثانياً: نتائج تقييم المستفيدين للتصميمات المقترحة لملابس السهرة الحريمي بإستخدام أقمشة

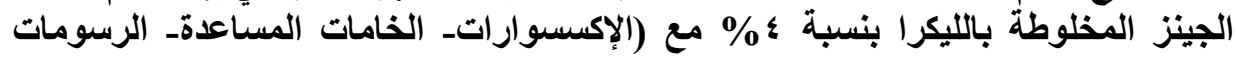

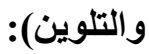

ا ـ توجد فروق ذات دلالة إحصائية بين التصميمات المقترحة في تحقيق جو انب التقييم (ككل)

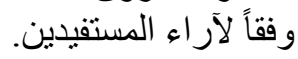

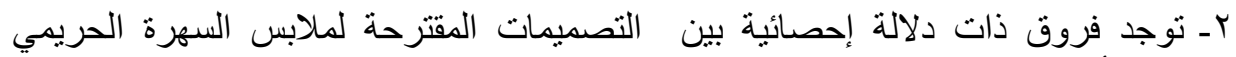

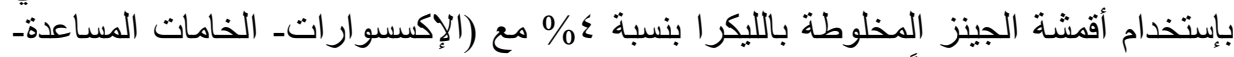
الرسومات و التلوين) وفقاً لآر اء المستقفيدين.

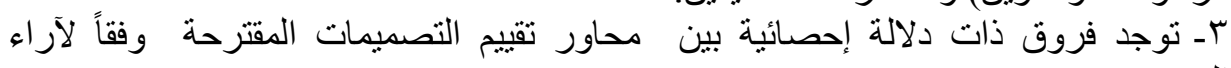
ثالثا: مناقثنة العلاقة الإرتباطية بين نتائج البحث في ضوه آراء المتين المتضصصين، وآراء

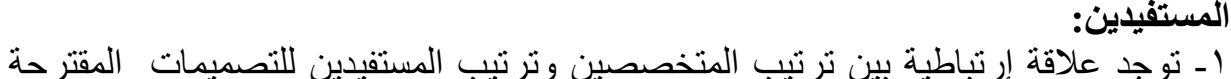

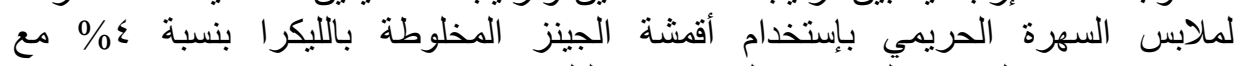

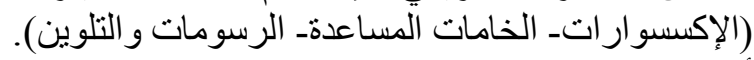

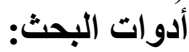

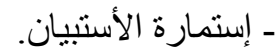
- إنتمارة تحكيم تصميمات ملابس السئن.

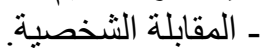

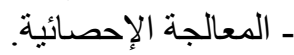

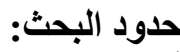
أـ حدود البحث النظرية: درو استة كلاً من: 1 - التركيب النسجي للجينز.

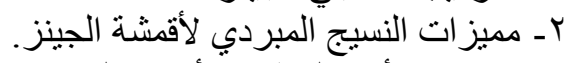

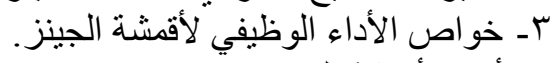
عـ أنواع أقمشة الجينز.

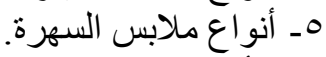
Tـ الأقششة المستخدمة في ملابس السهرة.

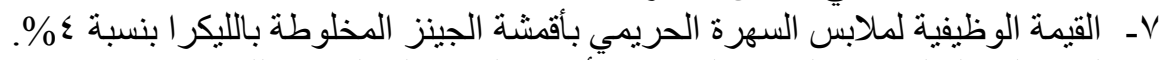

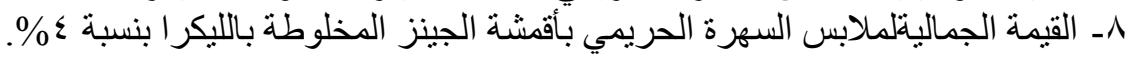




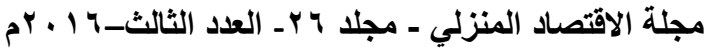

ب- حدود الاراسة التطبيقية:

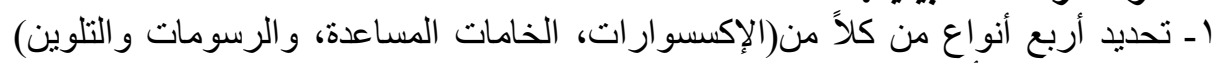

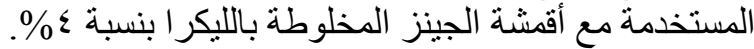

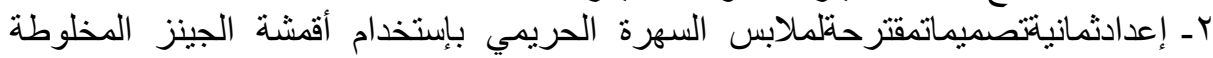

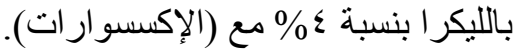

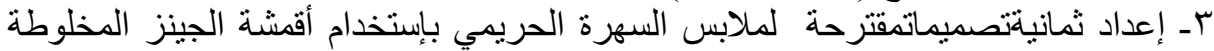

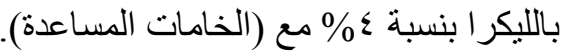

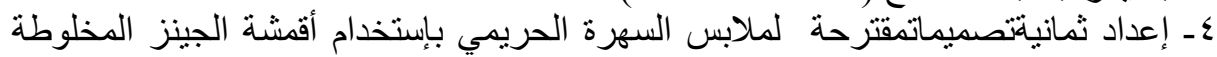

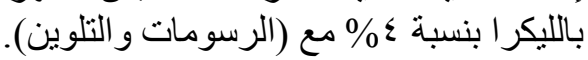

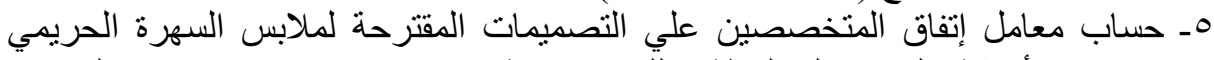

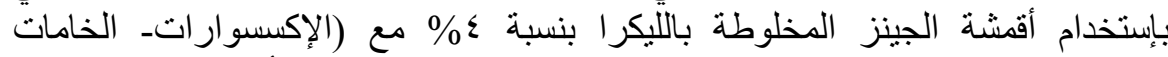

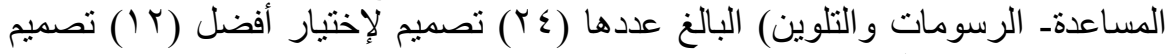
يتم تصميمها تمهيدا لتنفيذها. التهات T- إعداد إستمارة إستبيان لتحكيزمان تصميمات ملابس السهرة الحريمي المقترحة (أثنى عشر

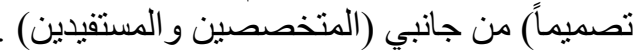

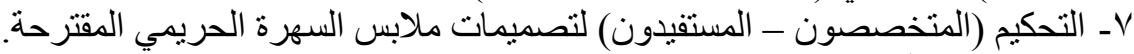
ج- الحدود المكانية: جمهورية مصر العنية العربية.

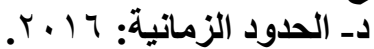

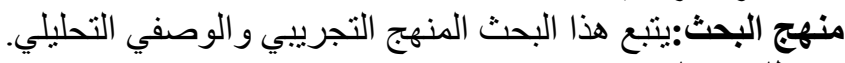

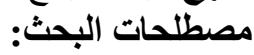

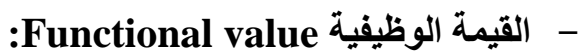

من أهم العوامل التي تساعد على نجاح تصميم العمل الفني للغرض الذي الذي صمم من أجله،

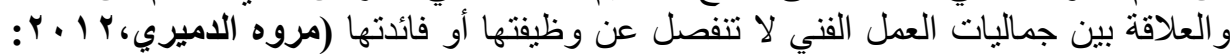

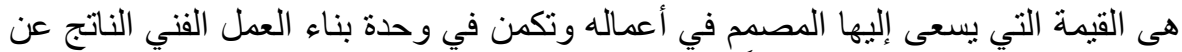

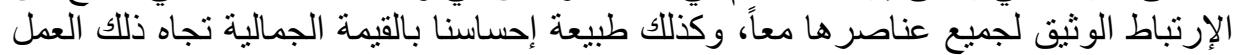

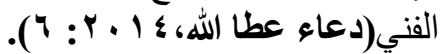

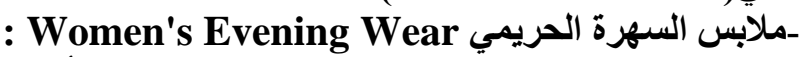

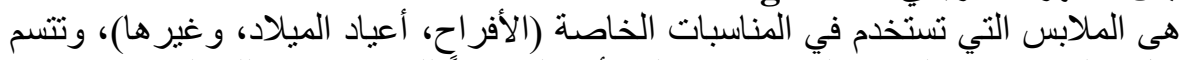

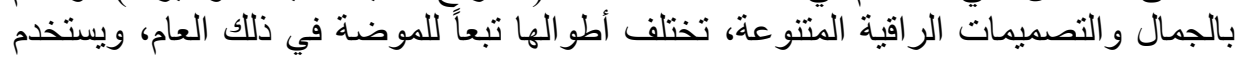

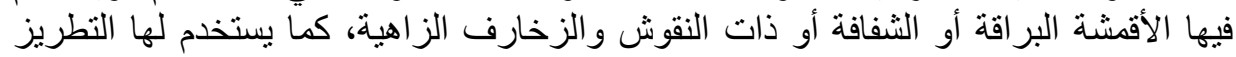

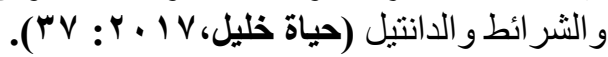

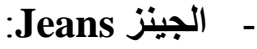

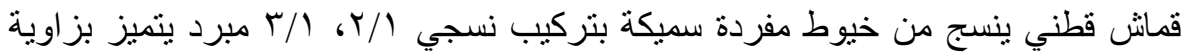

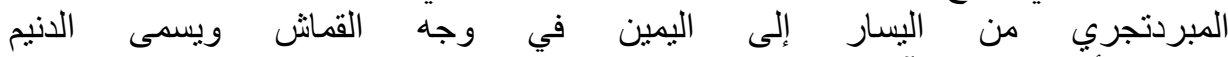

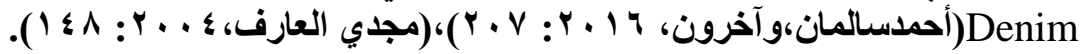




$$
\text { مجلة الاقتصاد المنزلي - مجلد Y Y - العدد الثالث-7 } 1 \text { • بم }
$$

-

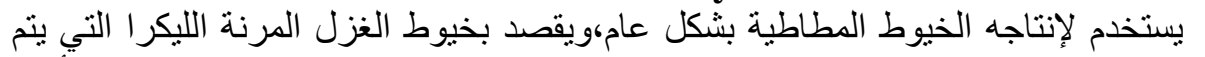

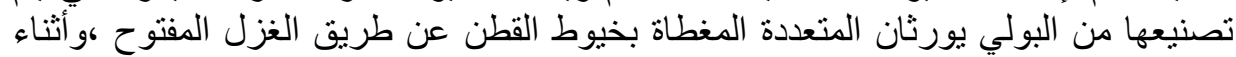

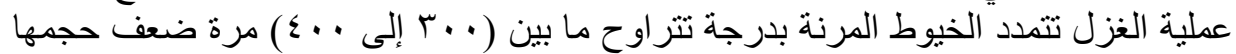

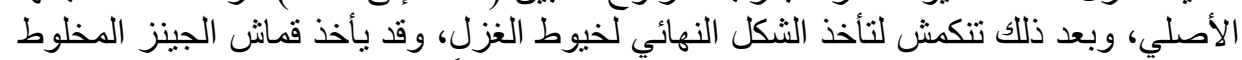

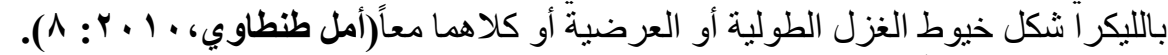

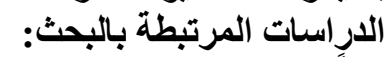

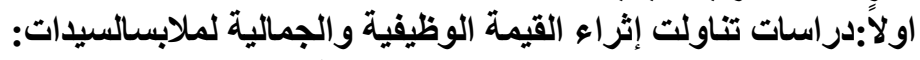

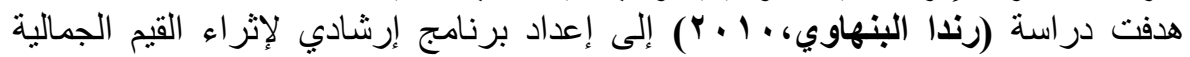

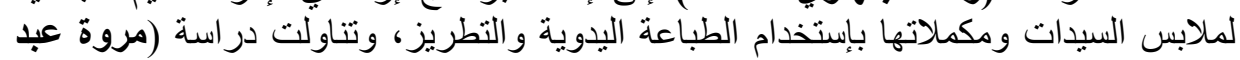

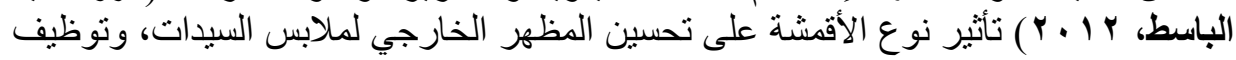

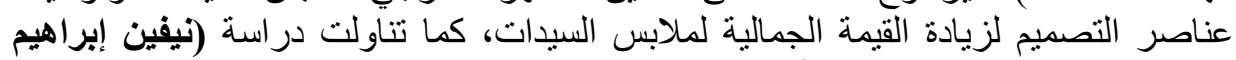

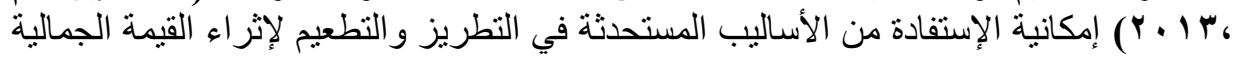

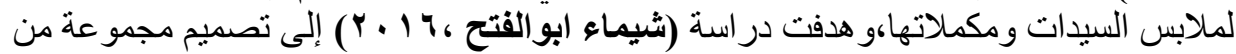

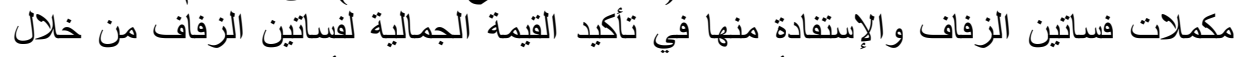

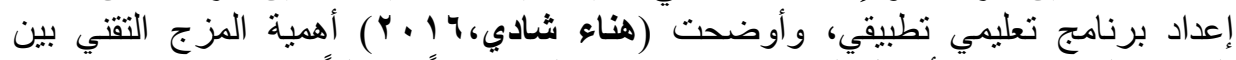

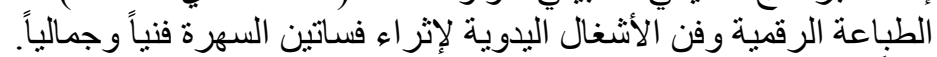

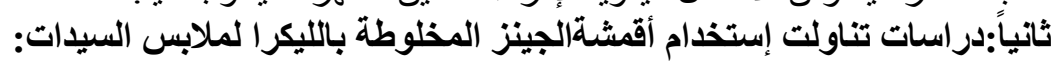

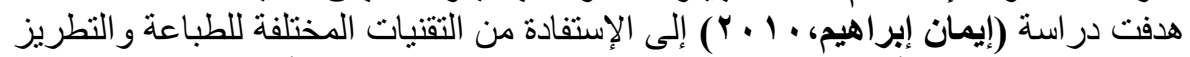

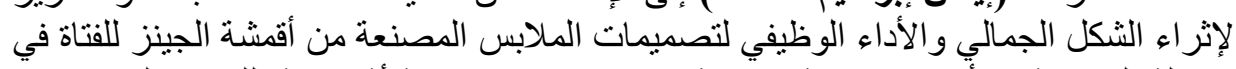

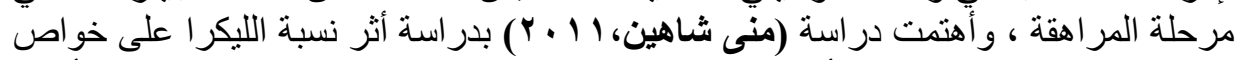

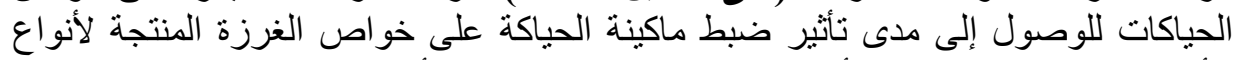

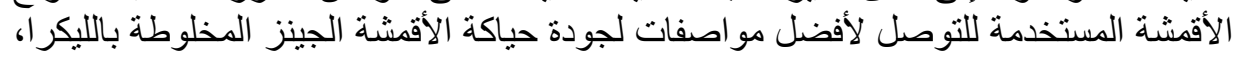

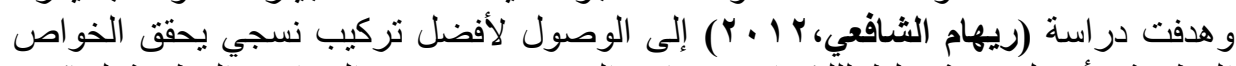

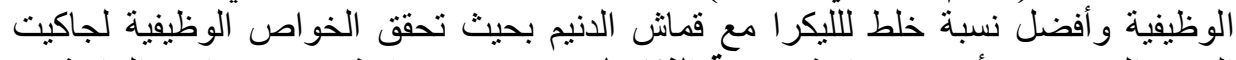

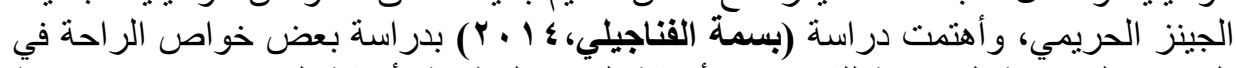

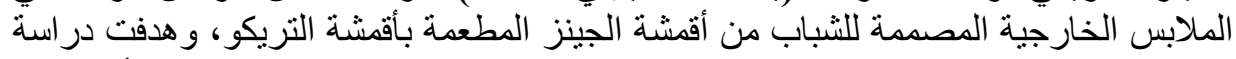

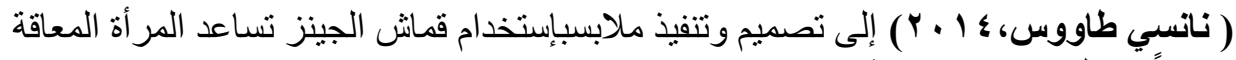

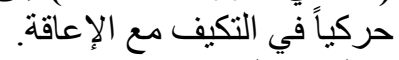

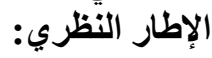

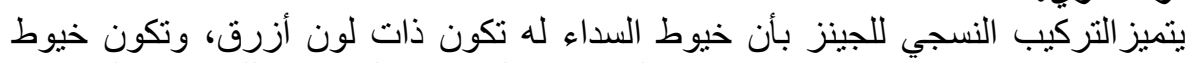

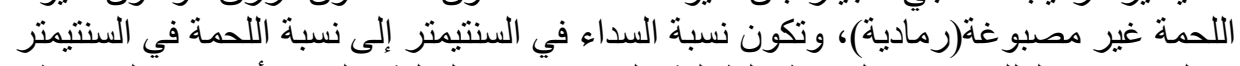

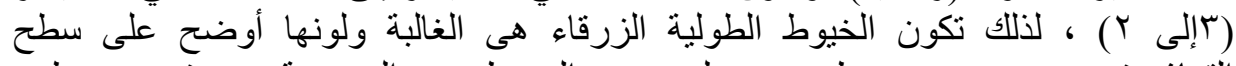

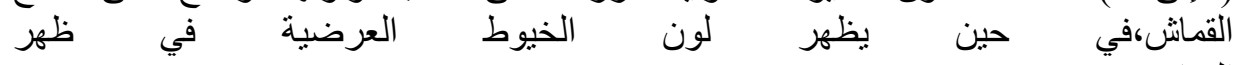
القماش1https://en.wikipedia.org/wiki/Denim).

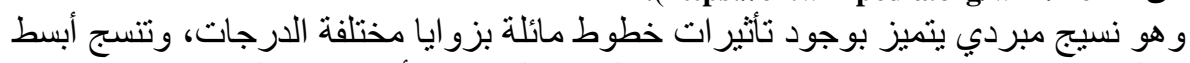

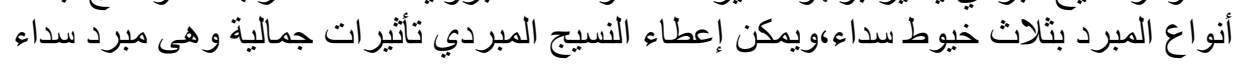




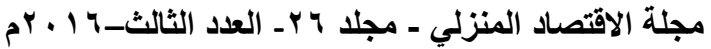

(تكون خيوط السداء على وجه القماش أكثر من خيوط اللحمة)،ومبرد لحمة (تكون خيوط

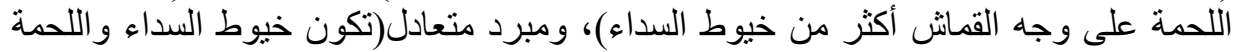

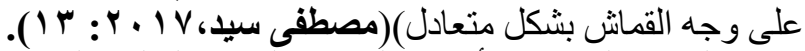

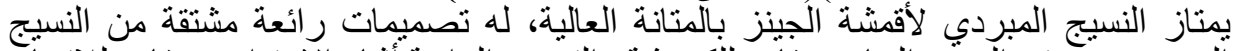

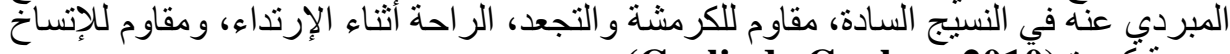

بدرجة كبيرة.(Gerlinde Gruber ,2010) وتنقسم خواص الأداء الوظيفي لأقمشة الجينز إلى:

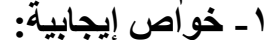
تتضمن الثشل النوعي المبذول، المتانة، مقاومة التمزق، مقاومة الكرمشة، نفاذية الهواء،

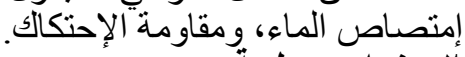

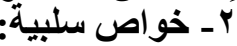

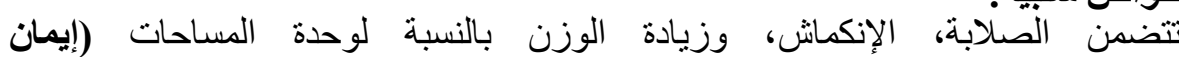

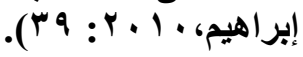
جدول (1) أنواع أقمشة الجينز

\begin{tabular}{|c|c|c|}
\hline وصفه & أنواع أقمشة & p \\
\hline 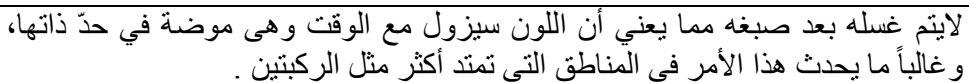 & أو الجينز الخاف & -1 \\
\hline 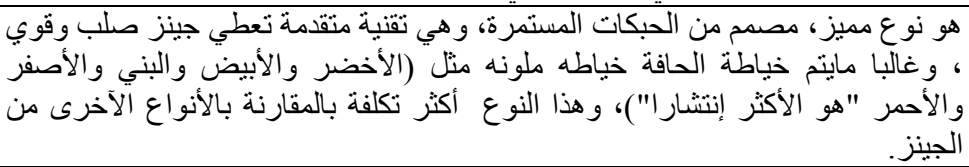 & الجينز ذو & $-Y$ \\
\hline 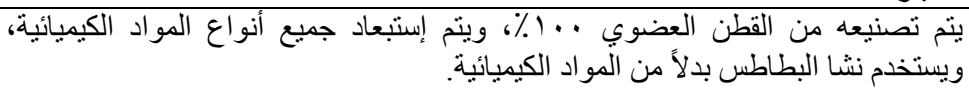 & العضيز & $-r$ \\
\hline 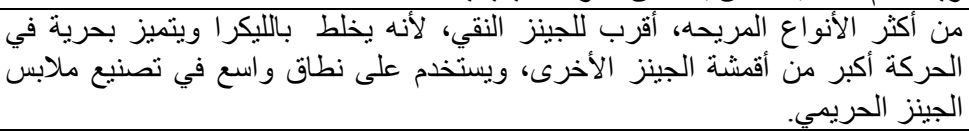 & المخلزوط & $-\varepsilon$ \\
\hline 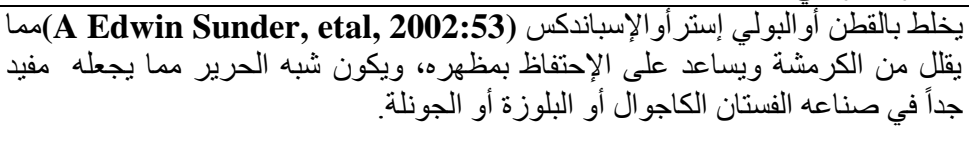 & المخلينز & -0 \\
\hline 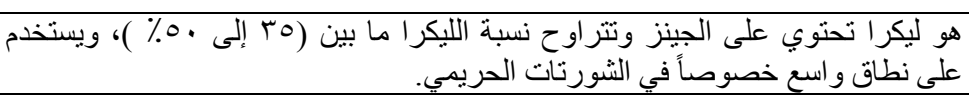 & 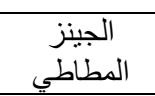 & -7 \\
\hline التبييض نسجه مع أكثر من لحمة ، ويغسل النسيج، ويمكن تحسين تأثثر التمزيق بأستخدام & 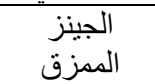 & $-V$ \\
\hline 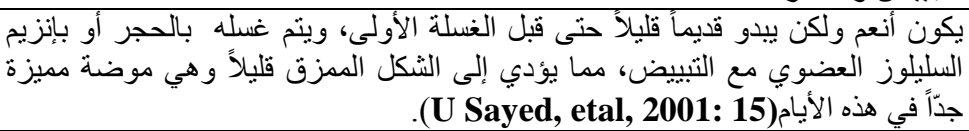 & المغينز & $-\Lambda$ \\
\hline المغذول في أخل الرخام وذلك بغسل الجينز مع محلول تبيضض قوي، ويطلق عليه أيضاً الجينز & 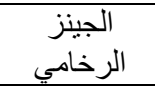 & -9 \\
\hline
\end{tabular}

(https://www.iravin.com/blog/\%D9\%A9-\%D8\%A7\%D9\%86\%D9\%88\%D8\%A7\%D8 \%B9-\%D9\%85\%D9\%86-\%D8\%A7\%D9\%84\%D8\%AF\%D9\%8A\%D9\%86\%D9\%85\%D9\%88-\%D8\%AA\%D8\%A7\%D8\%B1\%D9\%8A\%D8\%AE-\%D8\%A7\%D9\%84\% D8\%AF\%D9\%8A\%D9\%86\%D9\%85-history-denim-9-/different). 
تتتوع ملابس السهرة ما بين ملابس الحفلات الرسمية، ملابس العشاء، معاطف المساء

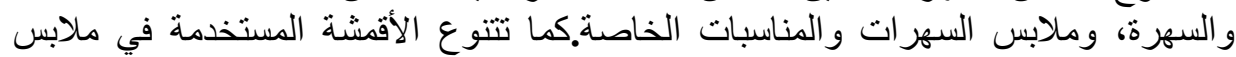

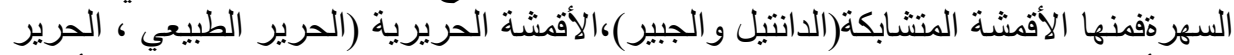

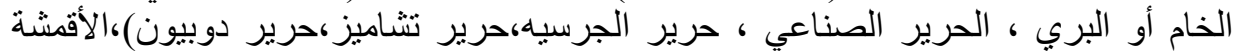

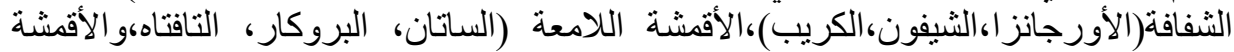

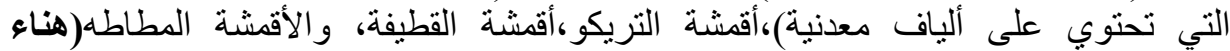

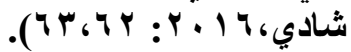
وأختارت الباحثة أقمشة الجينز المخلوطة باللبكر ا بنسبة ؛ \%؛ وتعتبرمن الأقمشة الجديدة

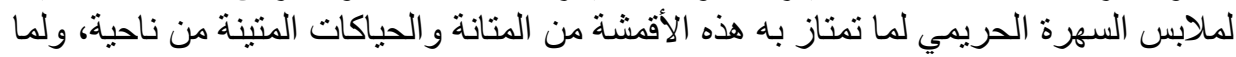

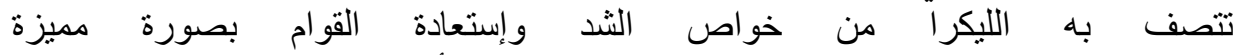
(https://en.wikipedia.org/wiki/Spandex)

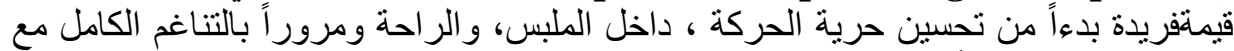

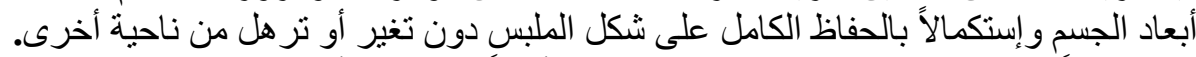

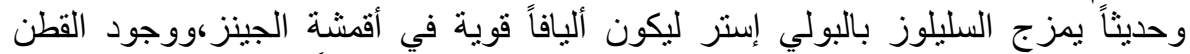

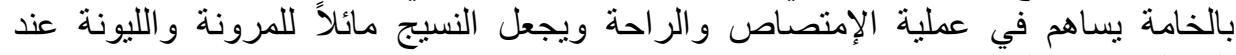
الغسيل، بينما البولي إستر يساهم في مقاومة الإنكماش (Asim Choudhury, 2017:406).

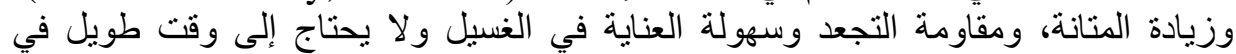

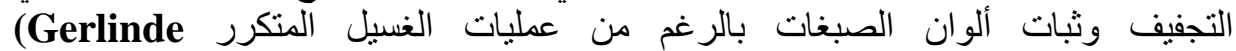

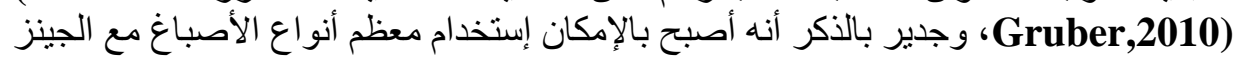

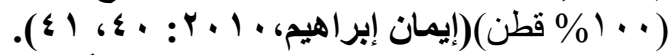

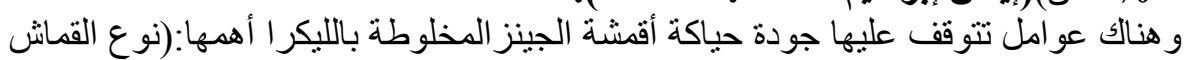

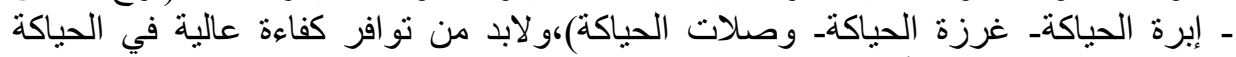
لتحقيق القوة و التحمل والأمان و الر احة (A. (A.

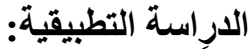

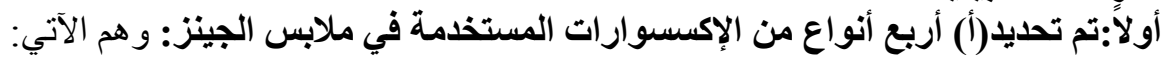

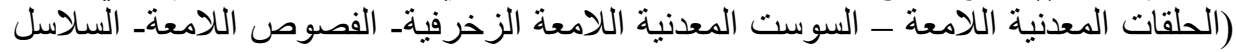

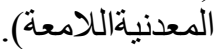

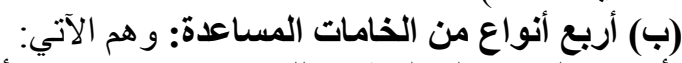

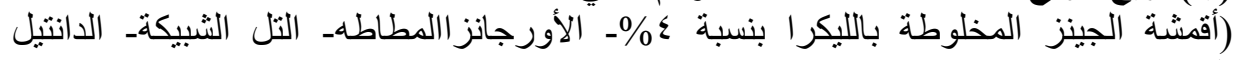
المطاطي). (ج) وأربيع أثكال من التلوين: وهم الآتي:

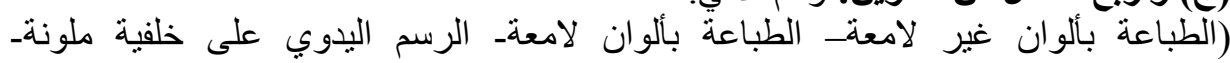
الرسماليدوي بدون خلفية ملونة). ثناتياً:تم إعداد تصميمات ملابس السهرة المنابة المقترحة :

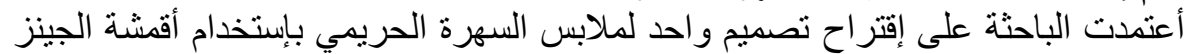

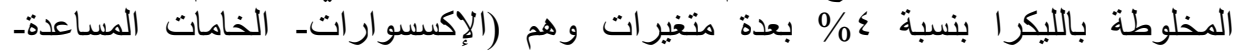




\section{مجلة الاقتصاد المنزلي - مجلد ج r ـ العدد الثالث_r 1 • r م}

الرسومات والتلوين) كل منغير منهم لله ثمانية تصميمات مختلفة، ليصبح العدد الكلي

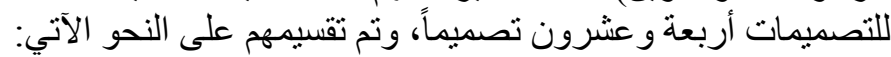

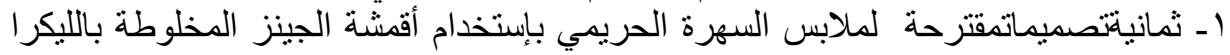

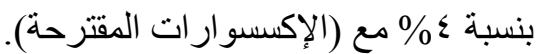

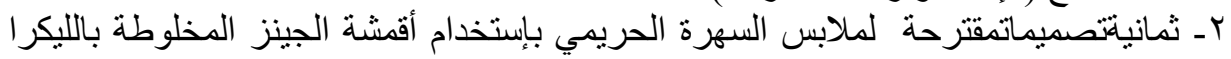
بنسبة ؛ \% مع (الخامات المساعدة المقترحة).

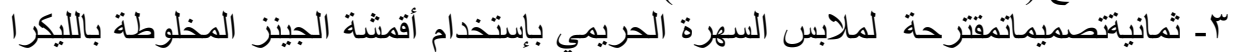

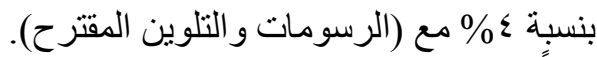

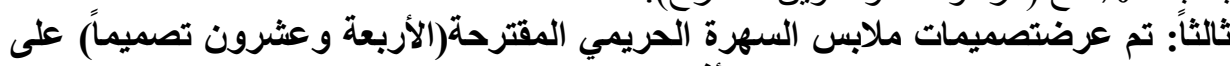

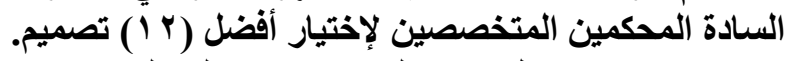

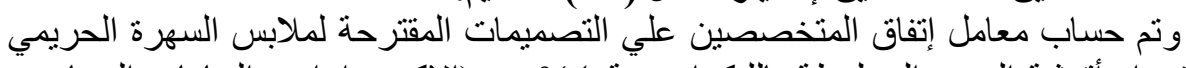

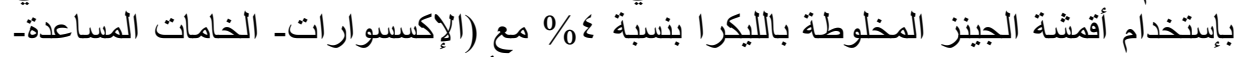

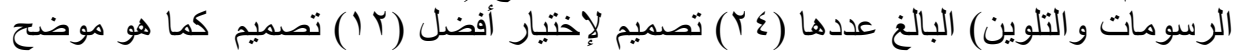

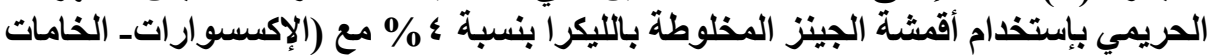

\begin{tabular}{|c|c|c|c|c|c|}
\hline التصمبيمدات & معامل الإتفاق & عدد مرات عدم الإتفاق & عدد مرات الإتفاق & التصميم & \\
\hline & $\% \wedge \varepsilon .7 Y$ & $r$ & 11 & 1 & \multirow{8}{*}{ الإكسسوارات } \\
\hline \multirow[t]{2}{*}{$\sqrt{ }$} & $\%$ & 11 & $r$ & $r$ & \\
\hline & $\% \vee 7.9 Y$ & $r$ & 1. & $r$ & \\
\hline$\sqrt{ }$ & $\% \Gamma \cdot . V \vee$ & 9 & $\varepsilon$ & $\varepsilon$ & \\
\hline \multirow[t]{3}{*}{$\sqrt{ }$} & $\%$ \%T.A & 1. & $\mu$ & 0 & \\
\hline & \%79.Y & $\varepsilon$ & 9 & 7 & \\
\hline & $\% \wedge \varepsilon .7 \gamma$ & $r$ & 11 & $\mathrm{~V}$ & \\
\hline \multirow[t]{2}{*}{$\sqrt{ }$} & $\%$ \%人.ะไ & $\Lambda$ & 0 & $\Lambda$ & \\
\hline & \%9r.Y & 1 & IT & 1 & \multirow{8}{*}{ الخامات المساعدة } \\
\hline$\sqrt{ }$ & $\%$ YT.A & 1. & $r$ & r & \\
\hline$\sqrt{ }$ & $\%$ \%^.รา & $\Lambda$ & 0 & $r$ & \\
\hline$\sqrt{ }$ & $\% \leq 7.10$ & V & 7 & $\varepsilon$ & \\
\hline & \%9r.rו & 1 & IT & 0 & \\
\hline \multirow[t]{3}{*}{$\sqrt{ }$} & $\% \vee .79$ & Ir & 1 & 7 & \\
\hline & $\% \wedge \varepsilon .7 \gamma$ & $r$ & 11 & $\mathrm{~V}$ & \\
\hline & $\% \vee 7.9 Y$ & $r$ & 1. & $\Lambda$ & \\
\hline$\sqrt{ }$ & $\%$ & 11 & $r$ & 1 & \multirow{8}{*}{ والتلوسومات } \\
\hline$\sqrt{ }$ & $\%$ \% . & 1 . & $r$ & $r$ & \\
\hline \multirow[t]{5}{*}{$\sqrt{ }$} & $\%$ \%人.รᄀ & $\Lambda$ & 0 & $r$ & \\
\hline & \%9r.r। & 1 & IT & $\varepsilon$ & \\
\hline & $\% \wedge \varepsilon .7 \gamma$ & 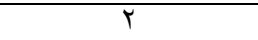 & 11 & 0 & \\
\hline & $\% \vee 7.9 Y$ & $r$ & 1. & 7 & \\
\hline & \%qr.r। & 1 & IT & $V$ & \\
\hline$\sqrt{ }$ & $\% \leq 7.10$ & $V$ & 7 & $\Lambda$ & \\
\hline
\end{tabular}




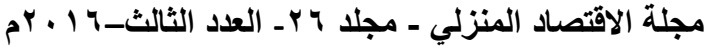

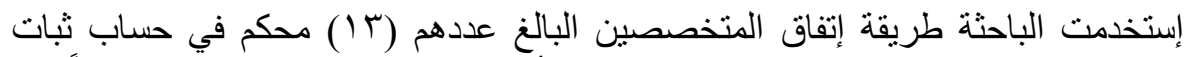

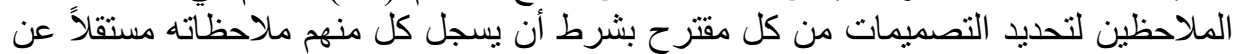

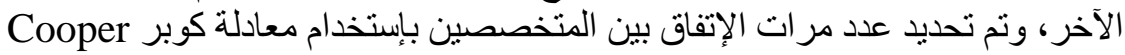

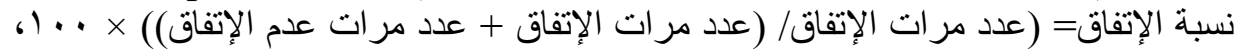

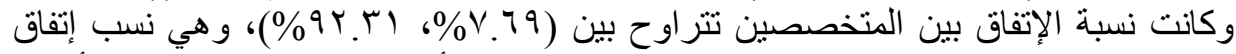

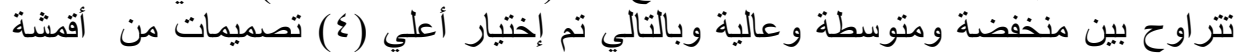

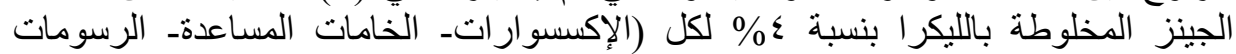

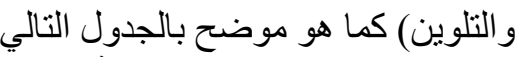

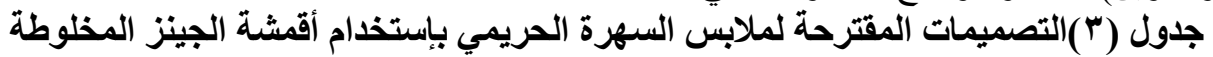

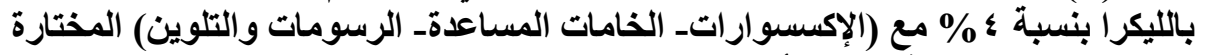

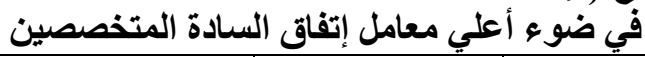

\begin{tabular}{|c|c|c|c|c|}
\hline معامل الإتفاق & عدد مرات عدم الإتفاق & عدد مرات الإتفاق & التصميم & \\
\hline$\% \wedge \Sigma .7 Y$ & $r$ & 11 & 1 & \multirow{4}{*}{ الإكسسوارات } \\
\hline$\% \vee 7.94$ & $r$ & $1 \cdot$ & $r$ & \\
\hline \%79.YT & $\varepsilon$ & 9 & 7 & \\
\hline$\%$ \%ะ. TY & $r$ & 11 & 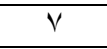 & \\
\hline \%9Y.r। & 1 & IT & 1 & \multirow{4}{*}{ الخامات المساعدة } \\
\hline$\% 94 . \Gamma$ & 1 & IT & 0 & \\
\hline$\%$ \%ะ. TY & $r$ & 11 & $\mathrm{v}$ & \\
\hline$\% \vee 7.94$ & $r$ & 1 . & $\Lambda$ & \\
\hline \%qY.r & 1 & IT & $\varepsilon$ & \multirow{4}{*}{ الرسومات والتلوين } \\
\hline$\% \wedge \varepsilon .7 Y$ & $r$ & 11 & 0 & \\
\hline$\% \vee 7.9 Y$ & $r$ & 1. & 7 & \\
\hline$\% q Y . r 1$ & 1 & Ir & V & \\
\hline
\end{tabular}

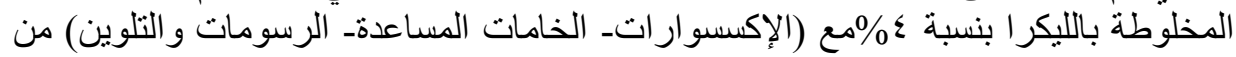

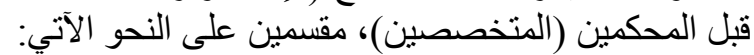

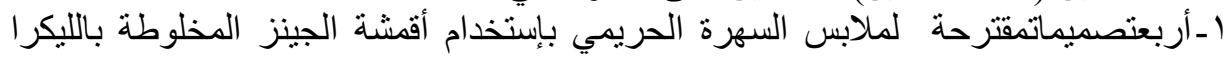

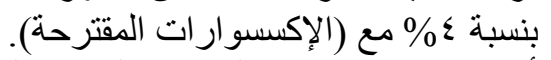

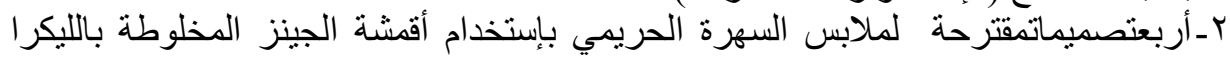
بنسبة ؟ ؟ ب مع (الخامات المساعدة المقترحة).

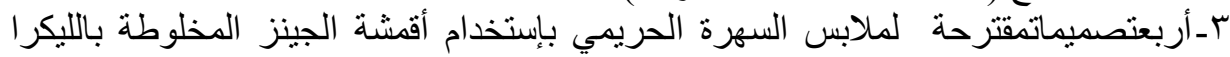

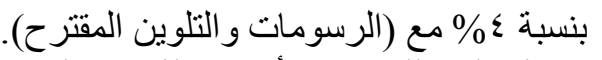

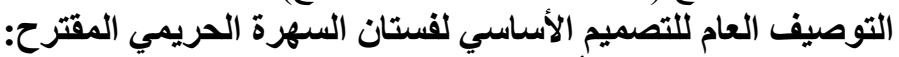

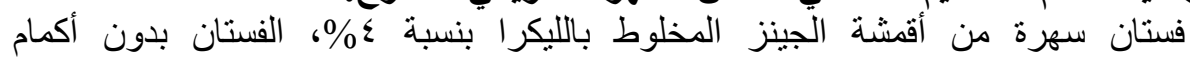

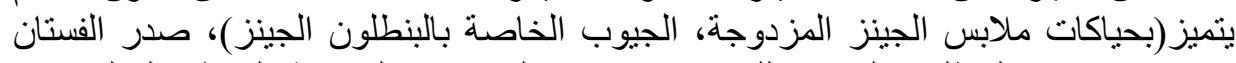

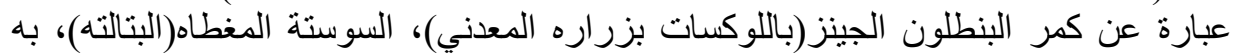
قصات زخرفية من الوسط حتى الجناب، ومن الجناب حتى الذيل به قصات الئ عرضية مائلة. 
مجلة الاقتصاد المنزلي - مجلد צ r ـ العدد الثالث_r 1 • r م

جدول (؛ ) توصيف التصميمات المقترحة

\begin{tabular}{|c|c|}
\hline التوصيف & التصميم \\
\hline 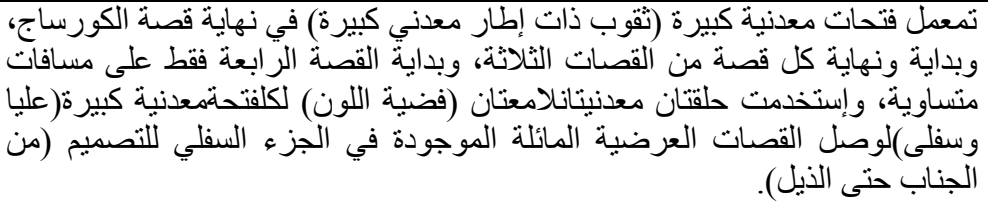 & التصميم الأول \\
\hline تم إستخدة الموجم السودة في الجزء الزخرفية المعلي للتصمية اللامعة (من الجناب حتية اللون الذيل) بين القصات العرضية & التصميم الثاني \\
\hline 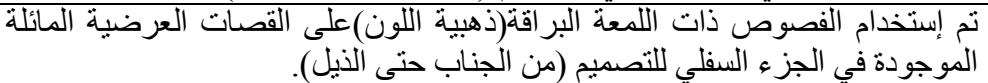 & التصميم الثالث \\
\hline 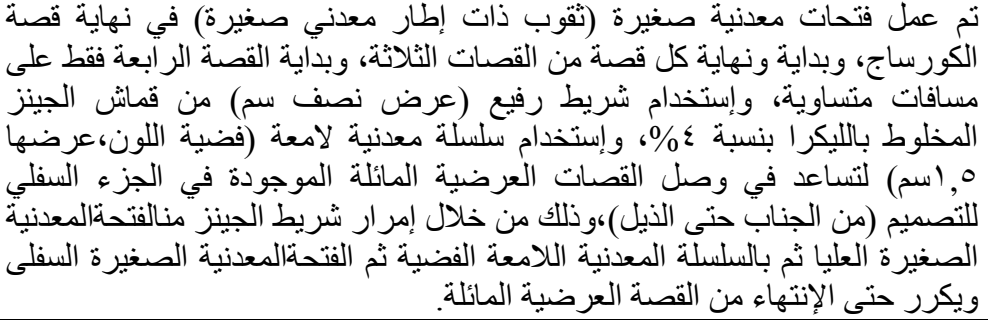 & التصميم الرابع \\
\hline 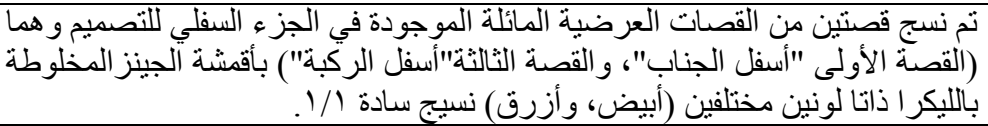 & التصميم الخامس \\
\hline 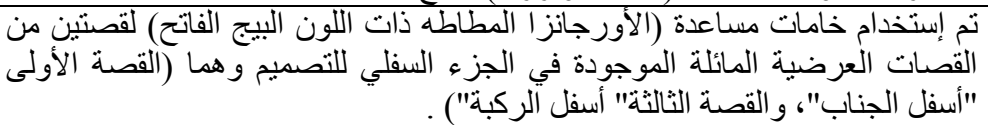 & التصميم السادس \\
\hline 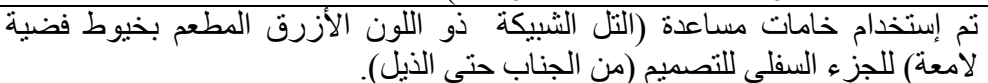 & التصميم السابع \\
\hline 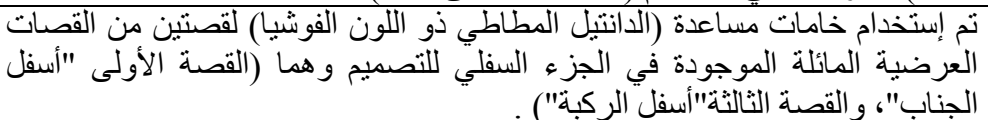 & التصميم الثامن \\
\hline 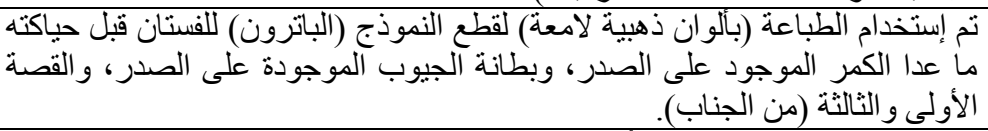 & التصميم التاسع \\
\hline 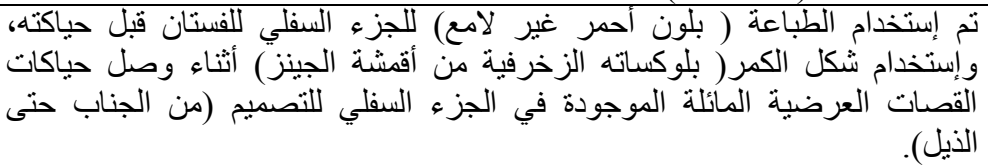 & التصميم العاشر \\
\hline 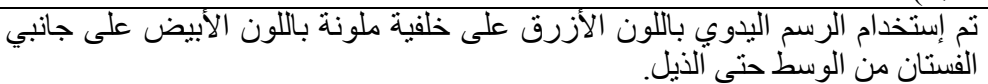 & التصميم الحادي \\
\hline 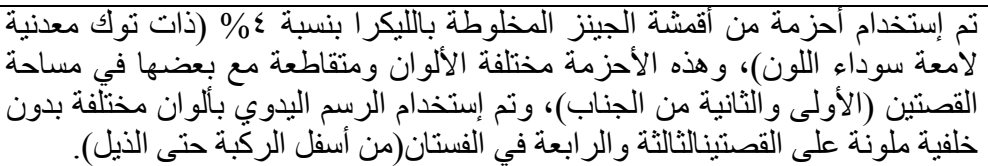 & التصميمـالثاني \\
\hline
\end{tabular}


مجلة الاقتصاد المنزلي - مجلد צr ـ- العدد الثالث-r 1 ـ rم

الأربع تصميمات المقترحة لملابس السهرة الحريمي بإستخدام أقمشة الجينز المخلوطة

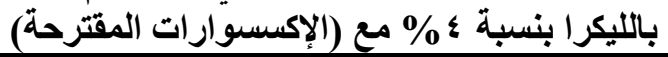

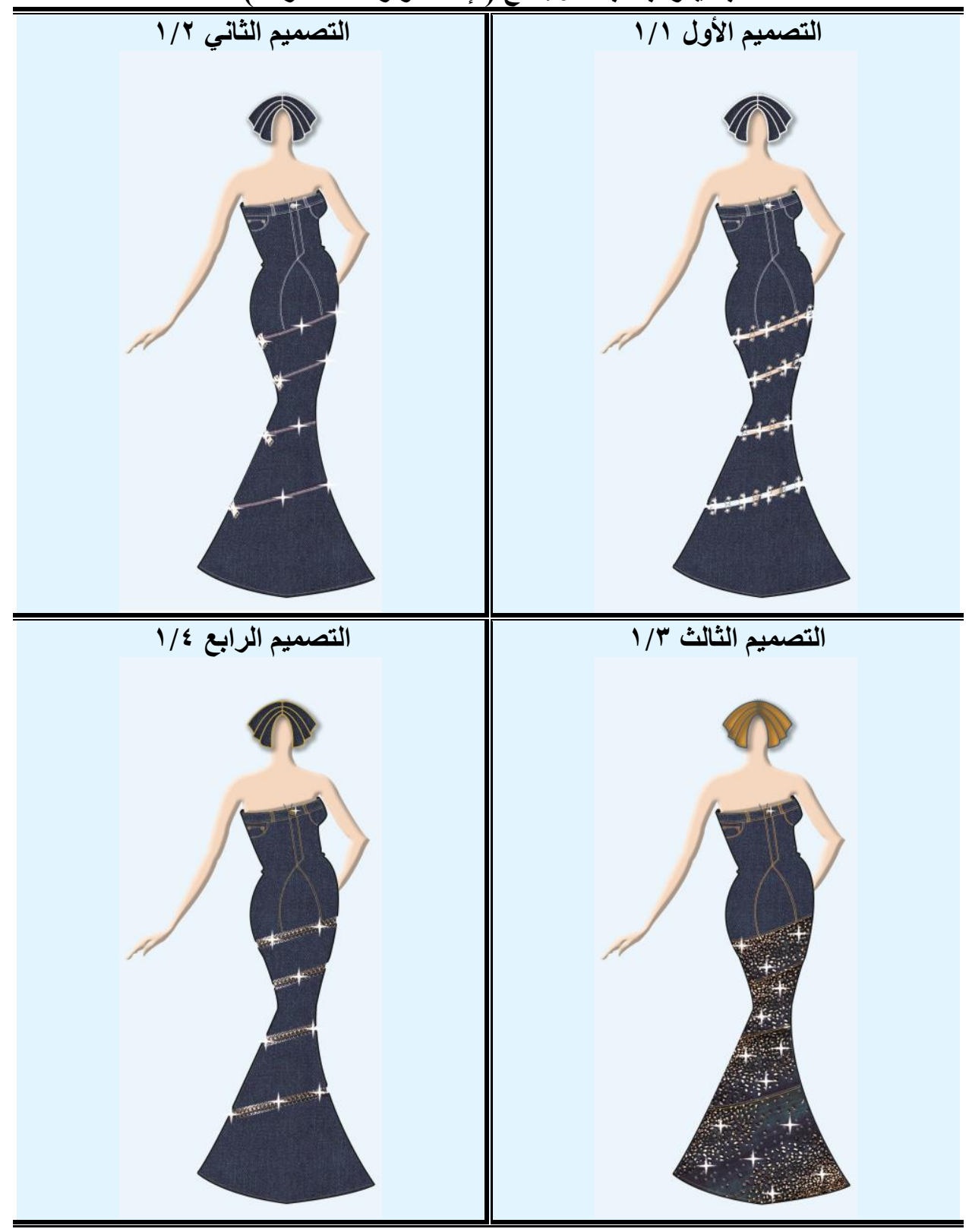


مجلة الاقتصاد المنزلي - مجلد ج r ـ العدد الثالث_r 1 • r م

الأربع تصميمات المقترحة لملابس السهرة الحريمي بإستخدام أقمشة الجينز المخلوطة بالليكر ا بنسبة ؛ \% مع (الخامات المساعدة المقترحة)

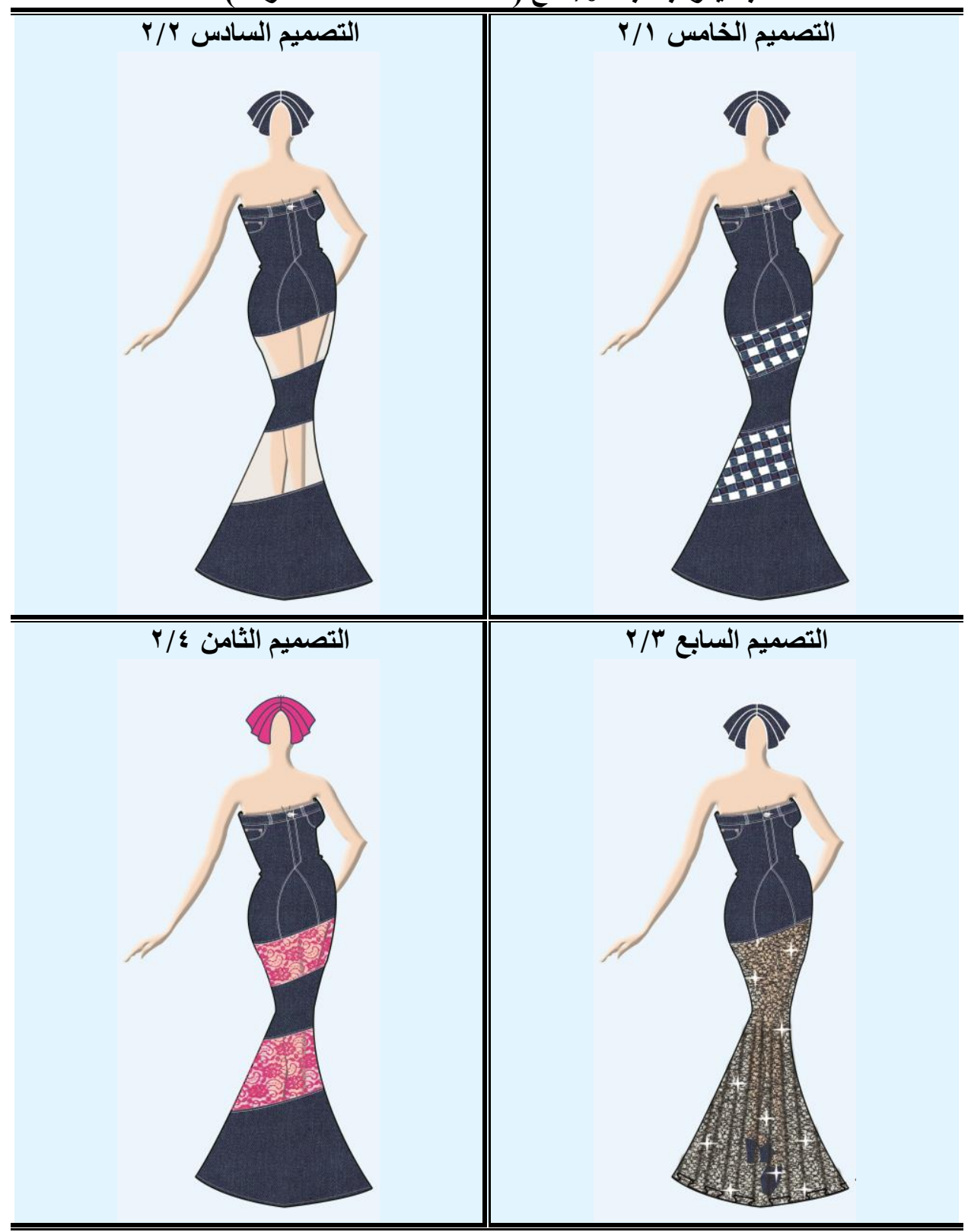


مجلة الاقتصاد المنزلي - مجلد 7 r- العدد الثالث-r 1 ـ بم

الأربع تصميمات المقترحة لملابس السهرة الحريمي بإستخدام أقمشة الجينز المخلوطة بإنة

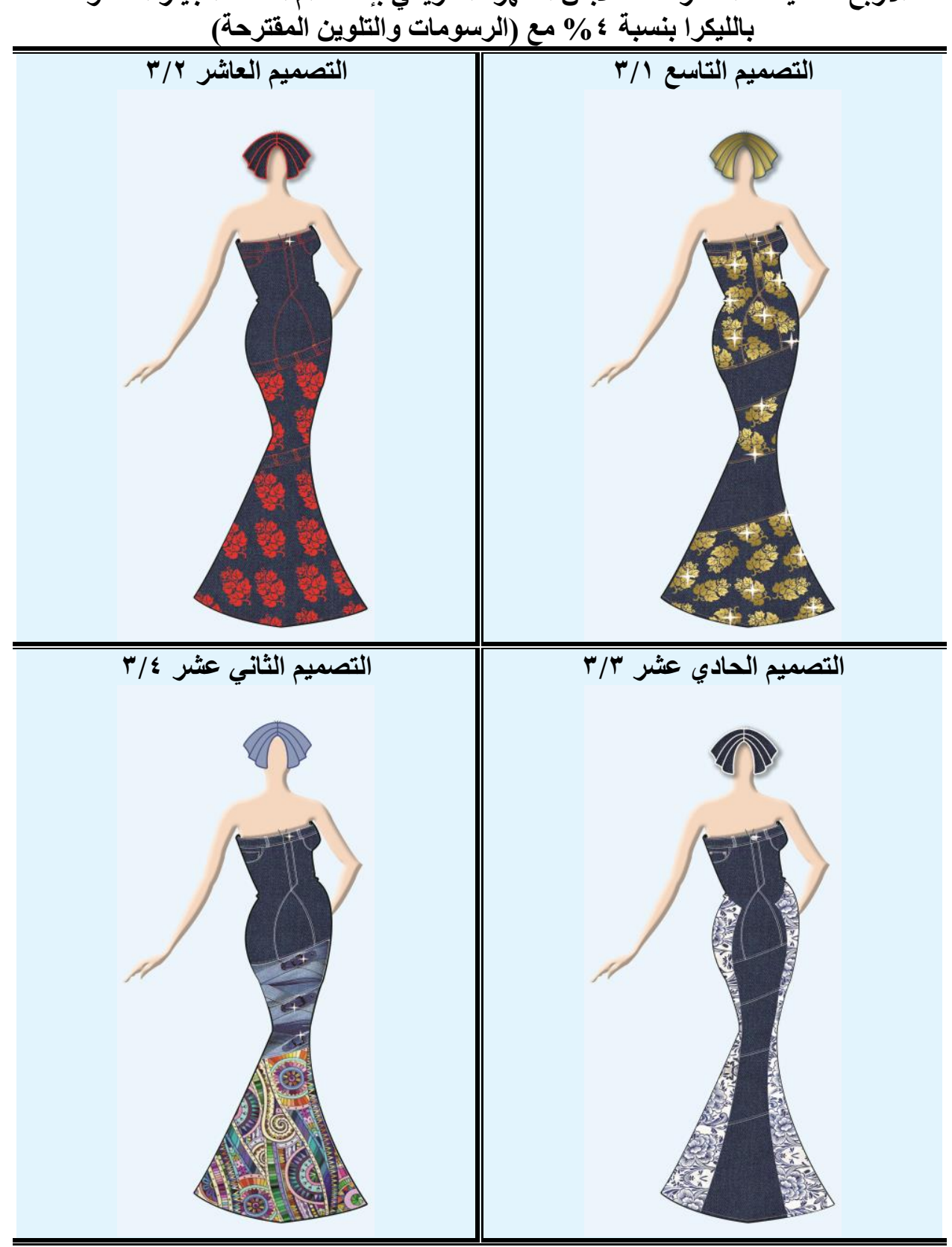




\section{مجلة الاقتصاد المنزلي - مجلد צr - العدد الثالث_r 1 • rم}

رابعاً: (أ) تم إعداد إستمارة إستبيان لتحكيم تصميمات ملابس السهرة المقترحة من جانبي (المتخصصين والمستفيدين): تقنين الأدوات (الصدق والثبنات الثين):

إستبيان تحكيم التصميمات المقترحة المبات لملابس السهرة الحريمي بإستخدام أقمشة الجينز

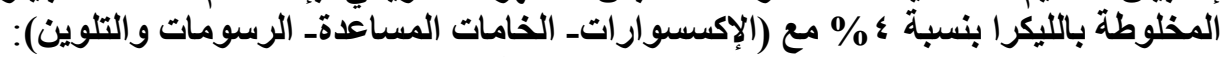

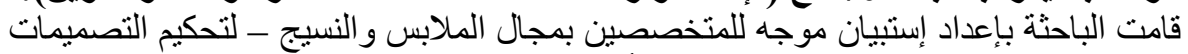

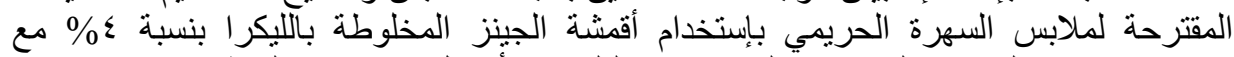

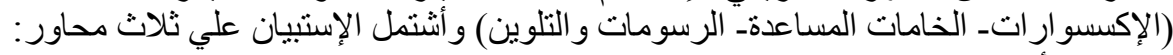

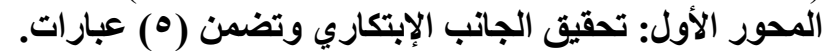
المحور الثاني: تحقيق الجاتب الوظيفي وتضمن الإنياري ونضين (0) عبارات.

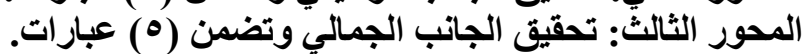

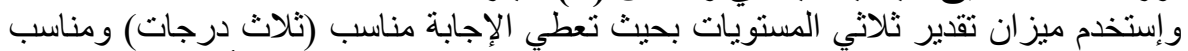

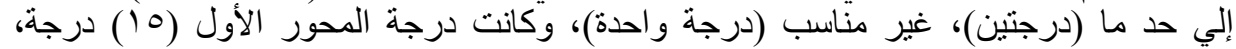

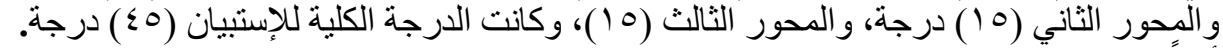
أولاً: صدق محتوي الإستبيان: صدق الإن المحكمين:

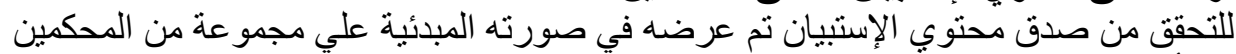

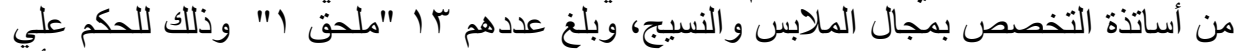

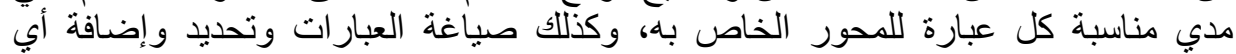

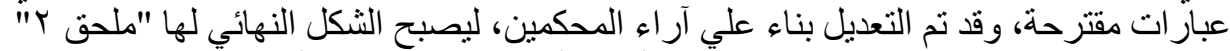

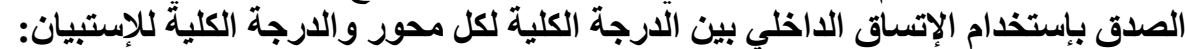

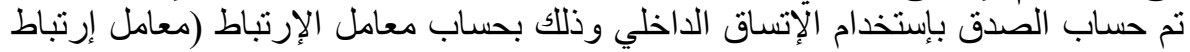

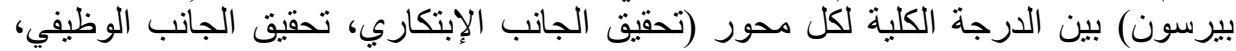

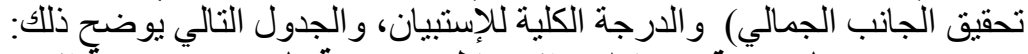
جدول (ه) قيم معاملات الإرتباط بين درجة كل محور ولئ ودرجةّ الإستبيان

\begin{tabular}{|c|c|}
\hline الإرتباط & 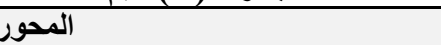 \\
\hline$* * .91$ & الأول: الجاتب الإبتكاري \\
\hline$* * .19$ & الثاني: تحقيق الجاتب الُوظيفي \\
\hline$* * .9 \%$ & الثالثة: تحقيق الجاتب الجمالي \\
\hline
\end{tabular}

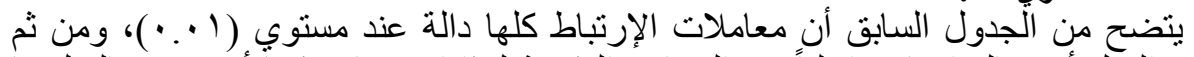

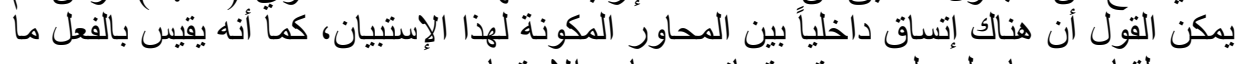

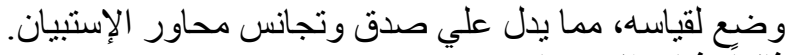

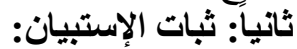

Alpha Cronbach للتحقق من ثبات الإستبيان تم حسابه عن طريق معامل ألفا كرونبان الإنبان جدول (7) قيم معامل الثبات لمحاور الإستبيان

\begin{tabular}{|c|c|}
\hline معامل ألفا & \\
\hline$* * \cdot .9 \cdot r$ & الأول: الجاتب الإبتكاري \\
\hline$* * . .9 \% r$ & الثاني: تحقيق الجاتب الوظيفي \\
\hline$* * . \wedge 9 \leq$ & الثُالث: تحقيق الجاتب الجمالي \\
\hline$* * .9 .9$ & ثُبات الإستبيان (ككل) \\
\hline
\end{tabular}


يتضح من الجدول السابق أن جميع قيم معامل ألفا كرونباخ Alpha Cronbach دالة إنب عند مستوي (1 ( . ) مما يدل علي ثبات الإسنبيان.

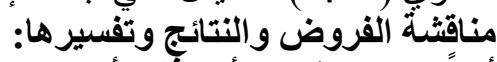

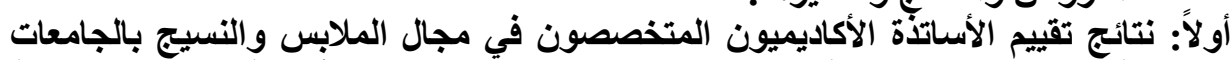

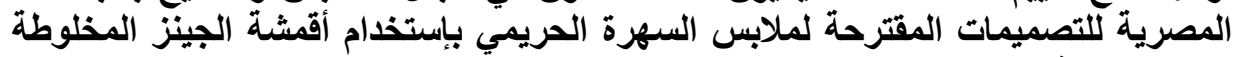

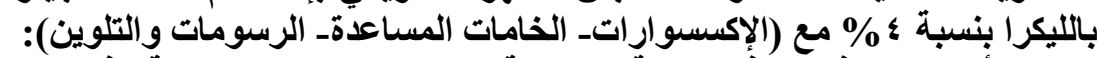

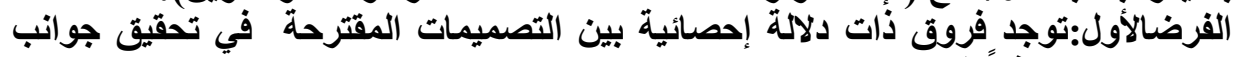

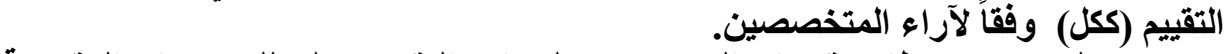
جدول (V) متوسطات تقييمات المتخصصين لمحاور التقييم (ككل) للتصميمات المقترحة

\begin{tabular}{|c|c|c|c|c|c|c|c|c|c|c|c|c|c|}
\hline \multicolumn{4}{|c|}{ المقترح الثالث } & \multicolumn{4}{|c|}{ المقترح الثاني } & \multicolumn{4}{|c|}{ المقترح الأول } & \multirow[b]{2}{*}{ المؤشر } & \multirow[b]{2}{*}{ الجاتب } \\
\hline |التصميم & ألتصميج & التصميم) & أتصميم & (التصميم & $\begin{array}{c}\text { 'لتصميم) } \\
\text { (V) }\end{array}$ & $\mid$ & \begin{tabular}{|l} 
(التصميم) \\
(0)
\end{tabular} & ألتصميم) & $\begin{array}{c}\text { لتصميم } \\
\text { (r) }\end{array}$ & 'التصميح) & |'آتصميم| & & \\
\hline rq & rq & rq & rq & rq & rq & rq & rq & rq & rq & ra & ra & 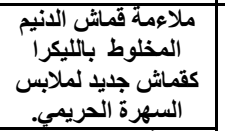 & \\
\hline ry & ז & rq & rq & rq & rq & rq & rq & rq & rq & rq & rq & 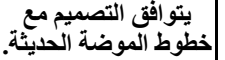 & \\
\hline rq & r & $r$ & rq & rq & rq & rq & rq & rq & rq & rq & rq & التجديد لملابس التصميم علىة. & الجاتبات \\
\hline ry & rq & rq & rq & rq & rq & rq & rq & rq & rq & rq & ra & التصميمات لها أفكار & \\
\hline rq & rq & r & rq & rq & rq & rq & rq & rq & rq & rq & rq & 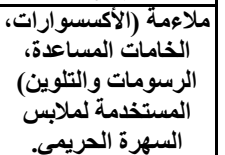 & \\
\hline rq & $r q$ & r & rq & rq & rq & rq & rq & rq & rq & rq & ri & يناسب سن (التصميم المرأة & \\
\hline$r 9$ & $r 4$ & $r 4$ & $r 4$ & $r q$ & rq & $r q$ & rq & $r q$ & $r q$ & rq & $r 9$ & التصميم يحقق الراحة. & \\
\hline rq & rq & rq & rq & rq & rq & rq & rq & rq & rq & rq & rq & يتميز التصميم بسهولة & \\
\hline ז & rq & ז & rq & rq & rq & rq & rq & rq & rq & rq & rq & "يساعد التصميم على الحركة. & الوظيفي \\
\hline rq & rq & ז & rq & rq & rq & rq & rq & rq & rq & rq & rq & 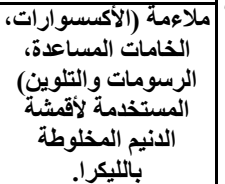 & \\
\hline 49 & $r 4$ & $r 4$ & 49 & rq & rq & $r 9$ & $r 9$ & & $r 9$ & r9 & & الثكل العام للتصميح. & \\
\hline rq & rq & r & rr & rq & rq & rq & צ & די & rq & rq & r & أنسبة واء التناسبب بين & \\
\hline ri & rq & rq & rq & ra & rq & rq & rq & rq & rq & rq & rq & |الجتينز المختلفيمة باللملابسة & الجمالي \\
\hline rq & r & q & $r r$ & rq & rq & rq & $r q$ & Y & rq & rq & Y & تناست الألكوان في & \\
\hline דוr & rq & Tr & rq & rq & $r q$ & $r q$ & rr & rq & rq & rq & rq & الزخرفي ميع التصميمي & \\
\hline
\end{tabular}




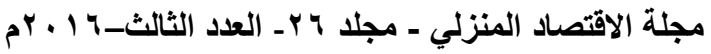

للتحقق من هذا الفرض تم حساب تحليل التباين لكتوسط التصميمات المقترحة في تحقيق

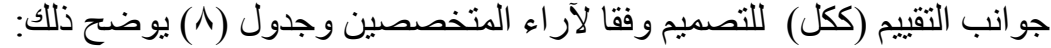

جذول (^) تحليل التباين لمتوسط التصميمات المقترحة في تحقيق جوانب التقييم (ككل) وفقا

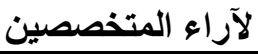

\begin{tabular}{|c|c|c|c|c|c|}
\hline الالالة & قيمة "ف" & متوسط المربعات & درجة الحرية & مجموع المربعات & جوانب التقييم \\
\hline \multirow{3}{*}{$\because \cdots$} & \multirow{3}{*}{0.999} & $V \cdot \Lambda \cdot r$ & 11 & $\checkmark \vee \wedge . \wedge I V$ & بين المجموعات \\
\hline & & $11 . \wedge . r$ & 171 & 19^r.9rT & داخل المجموعات \\
\hline & & & 189 & YVTI.VO. & المجموع \\
\hline
\end{tabular}

تشير نتائج الجدول السابق إلي أن قيمة (ف) كانت (999.0.99) وهي قيمة دالة إحصائياً عند

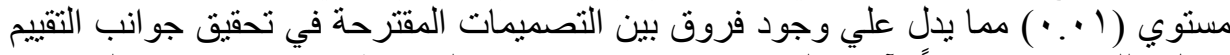

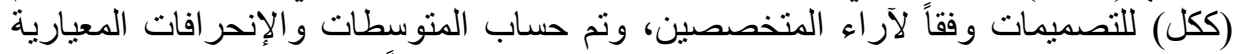

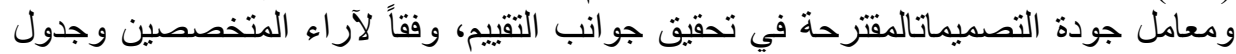

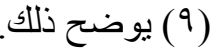

\begin{tabular}{|c|c|c|c|c|c|}
\hline التصميمات & معامل الجودة & الإنحرياري & المتوسط & التصميمات & 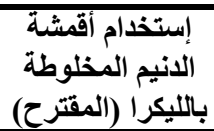 \\
\hline$r$ & זr.ז9 & $0 . \mu \Lambda$ & r... & التصميم 1 & \multirow{4}{*}{ الإكسسوارات } \\
\hline 1 & $1 \ldots$ & $\because \cdots$ & rq... & التصميم r & \\
\hline 1 & $1 \cdots$ & $\because \cdots$ & rq... & التصميم r & \\
\hline r & 90.07 & $\varepsilon .0 \mathrm{~V}$ & TV.rv & التصميم ؛ & \\
\hline 0 & 91.11 & 0.90 & ro.0T & التصميم • & \multirow{4}{*}{ المساعدة } \\
\hline 1 & $1 \ldots$ & $\because \cdots$ & rq... & التصميم 7 & \\
\hline 1 & $1 \ldots$ & $\because \cdots$ & rq... & V التصميم & \\
\hline 1 & $1 \ldots$ & $\because \cdots$ & rq... & التصميم & \\
\hline 7 & $\wedge \vee . \wedge T$ & $\varepsilon .0 \mathrm{~V}$ & $r \leqslant . r V$ & التصميم 9 & \multirow{4}{*}{ والتلويومات } \\
\hline V & $\wedge r . \leqslant r$ & 0.90 & r. Yor & التصميم · 1 & \\
\hline$\varepsilon$ & 94.4 & $\because \cdots$ & r... & التصميم 11 & \\
\hline$\varepsilon$ & qY.r. & $\because \cdots$ & r... & التصميم r I & \\
\hline
\end{tabular}

لتأكيد دلالة الفروق بين التصميمات المقترحة في ضوء آراء المتخصصين قامت الباحثة

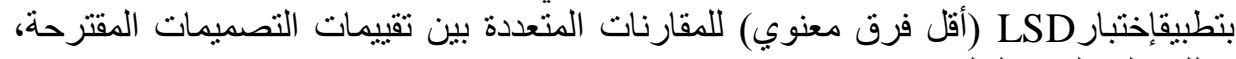
وذلك علي النحو التالي: 
مجلة الاقتصاد المنزلي - مجلد 7 r- العدد الثالث-r 1 ـ بم

جدول ( • 1) الفروق بين المتوسطات بإستخدام إختبار LSD (أقل فرق معنوي) للمقارنات

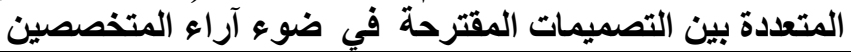

\begin{tabular}{|c|c|c|c|c|c|c|c|c|c|c|c|c|}
\hline التصميم & (التصميم) & (التصميم) & التصميم & |التصميم| & | التصميم| & |التصميم| & التصميم & |التصميم) & التصميم| & |التصميم| & |التصميم) & \\
\hline$\cdot \varepsilon$. & .. . & $* r . \wedge \uparrow$ & T.IT & *Y. . & $* Y .7$. & *Y.. &.$\wedge \mathrm{V}$ & $\therefore \wedge V$ & *Y.T. & *Y.. & & التصميم \\
\hline 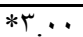 & $* r \ldots$ & $*\rceil . \leqslant V$ & $* \varepsilon . V T$ & $\because \cdots$ & $\because \cdots$ & $\because \cdots$ & $* r$ *Y & $1 . \mathrm{VT}$ & $\because \cdots$ & & & التصميم Y \\
\hline$* r . .$. & $* r . .$. & *ฯ. हV & $* \varepsilon . V \Gamma$ & $\because \cdots$ & $\because \cdots$ & $\because \cdots$ & $* r . \varepsilon V$ & $1 . V \pi$ & & & & التصميم r \\
\hline $1 . Y V$ & $1 . r V$ & $* \varepsilon, V \Psi$ & $* \mu \ldots$ & $1 . \mathrm{V \mu}$ & $1 . V T$ & $1 . V \mu$ & $1 . \mathrm{V} \mu$ & & & & & التصميم \& \\
\hline 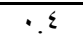 & 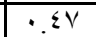 & *r... & $1 . r V$ & $* r . \leqslant V$ & $* r . \varepsilon V$ & $* r$ * $\leqslant V$ & & & & & & التصميم 0 \\
\hline *r... & $* r .$. & $* \tau . \varepsilon V$ & $* \varepsilon . V \Gamma$ & $\because \cdots$ & $\because \cdots$ & & & & & & & التصميم 7 \\
\hline$* r . .$. & $* r .$. & $* \tau . \varepsilon V$ & $* \varepsilon . V T$ & $\because \cdots$ & & & & & & & & التصميم V \\
\hline *r... & $* Y .$. & *ฯ. $\varepsilon V$ & $* \varepsilon . V T$ & & & & & & & & & التصميم 1 \\
\hline $1 . V \mu$ & $1 . V 4$ & $1 . V T$ & & & & & & & & & & التصميم 9 \\
\hline *r. $\leqslant V$ & $* r . \varepsilon V$ & & & & & & & & & & & التصميم. 1 \\
\hline \multirow[t]{2}{*}{$\because \cdots$} & & & & & & & & & & & & التصميم 11 \\
\hline & & & & & & & & & & & & التصميم r I \\
\hline
\end{tabular}

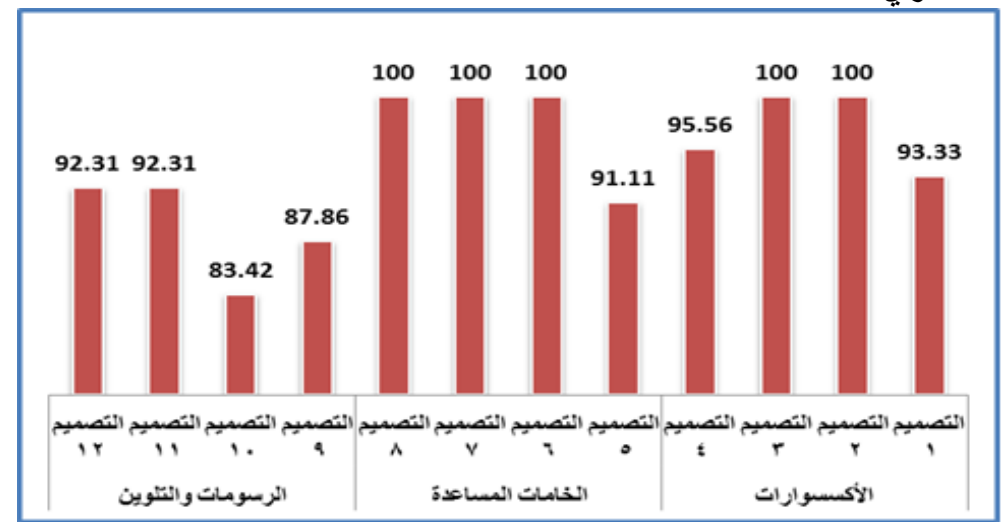

شكل ( 1 ) معامل الجودة للتصميمات المقترحة في تحقيق جوانب التقييم (ككل) وفقا لآراء المتخصصين

من الجدول (V) و الثكل (l) ) يتضح أن:

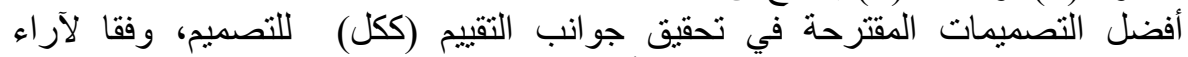

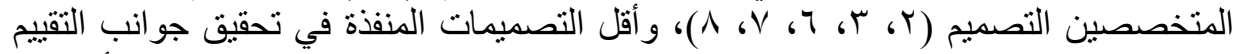

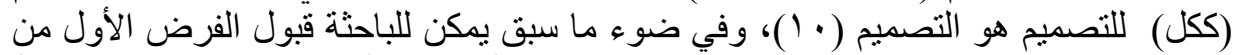

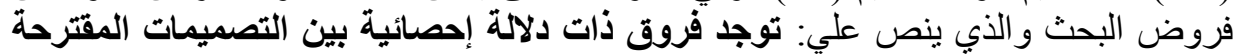

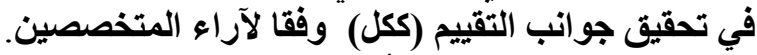

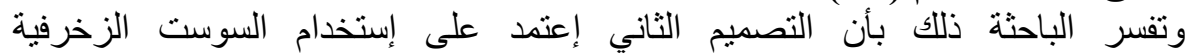

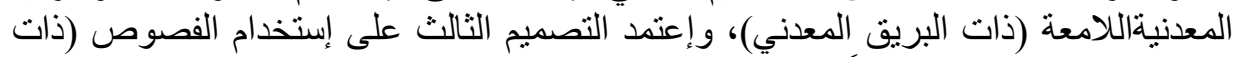

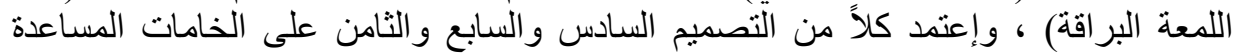
(الأورجانزا المطاطهـ التل الثبيكة ذو اللون الأزرق المطعم بخيوط فضية لامعة ــ الدانتيل 
المطاطي)اللآتي تشف الجسم، بما يتتاسب مع ملابس السهرة الحريمي من الناحية(الإبتكاريةـ

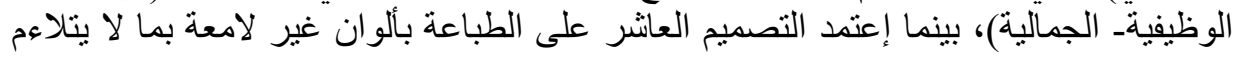

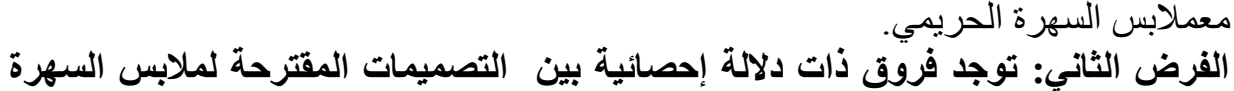

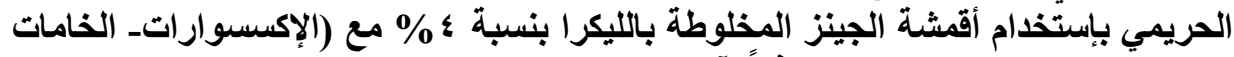

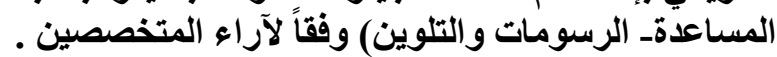

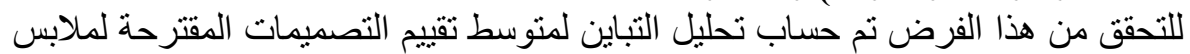

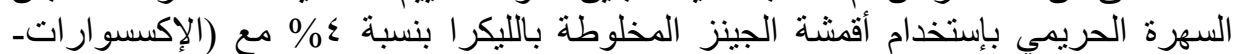

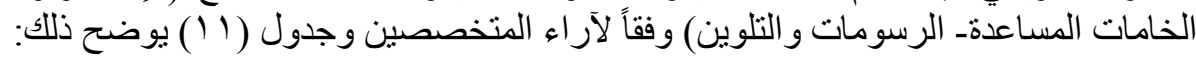

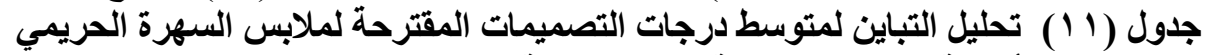

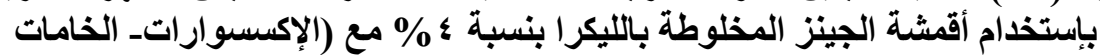

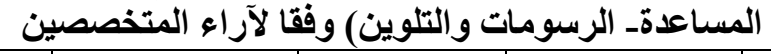

\begin{tabular}{|c|c|c|c|c|c|}
\hline الالالة & قيمة "ف" & متوسط المربعات & درجة الصرية & مجموع المربعات & محاور التقييم \\
\hline \multirow{3}{*}{$\because \cdots$} & \multirow{3}{*}{$17.9 \mathrm{rV}$} & YYI.AIV & $r$ & $\varepsilon \varepsilon r .7 T r$ & بين المجموعات \\
\hline & & $1 T .9 V$ & $I V V$ & rMIA.IIV & داخل المجموعات \\
\hline & & & 189 & YVTI.VO. & المجموع \\
\hline
\end{tabular}

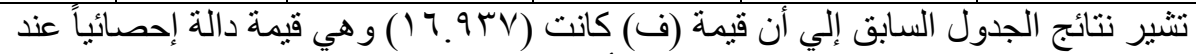

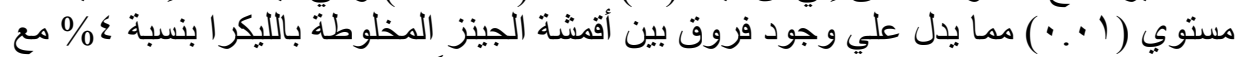

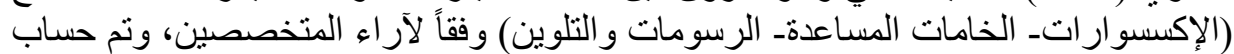

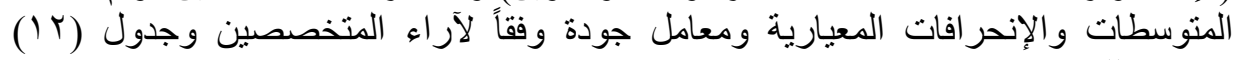
يوضح ذللك.

جدول (r أ) المتوسطات والإنحرافات المعيارية ومعامل الجودة لأقمشة الجينز المخلوطة بالليكرا

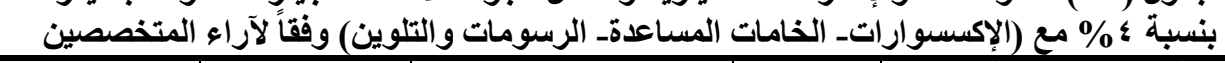

\begin{tabular}{|c|c|c|c|c|}
\hline ترتيب المحاور & معامل الجودة & الإنحراف المعياري & المتوسط & أقمشة الدنيم المخلوطة بالليكرا \\
\hline$r$ & QY.YY & r. Tr & rV.qY & الإكسسوارات \\
\hline$T$ & $9 \vee . \vee A$ & r.TV & $r \lambda .14$ & الخامات المساعدة \\
\hline$r$ & $\Lambda \Lambda .9 \mathrm{~V}$ & $r .94$ & $r \varepsilon . v$. & الرسومات والتلوين \\
\hline
\end{tabular}

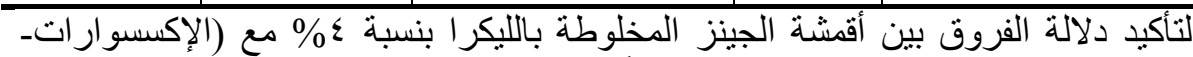

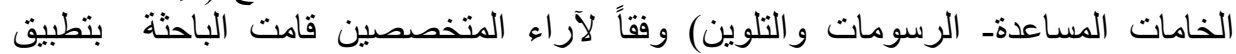
إختبار LSD (أقل فرق معنوي) للمقارنات المتعددة، وذللك علي النحو التالي:

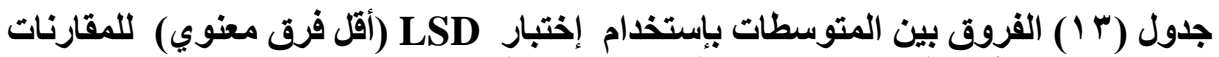

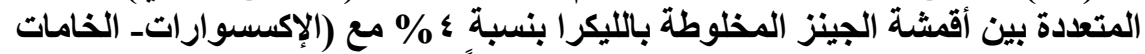

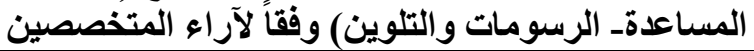

\begin{tabular}{|c|c|c|c|}
\hline الرسومات والتلوين & الخامات المساعدة & الإكسسوارات & \\
\hline$* r . Y 1$ &.$Y 17$ & & الإكسسوارات \\
\hline$* r . \leqslant r$ & & & الخامات المسـاعدة \\
\hline & & & الرسومات و التلوين \\
\hline
\end{tabular}




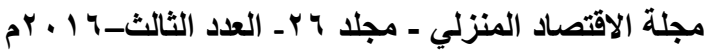

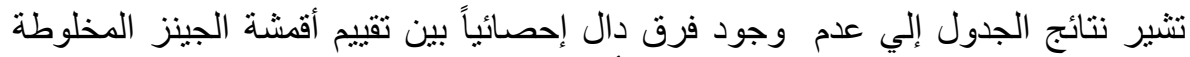

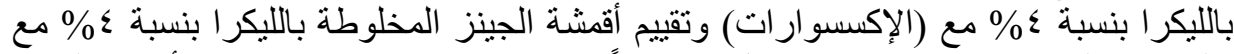

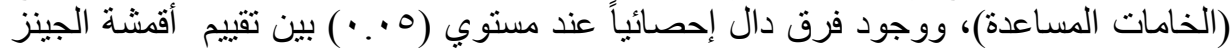

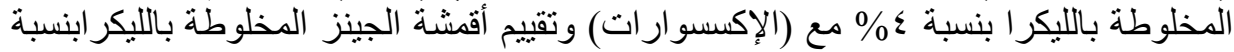

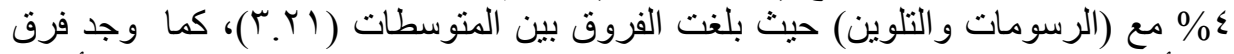

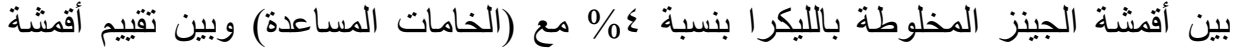

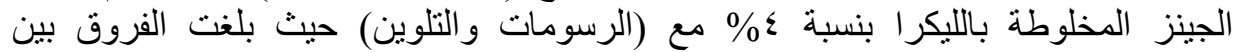

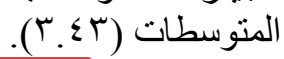

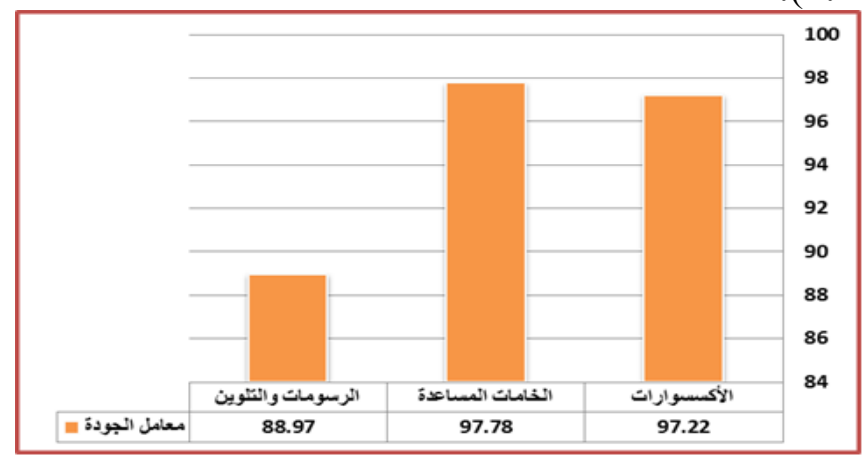

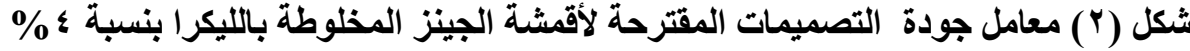

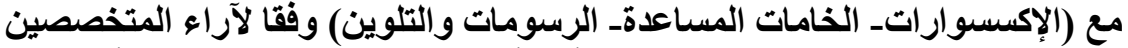

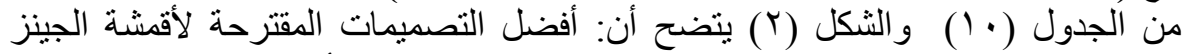

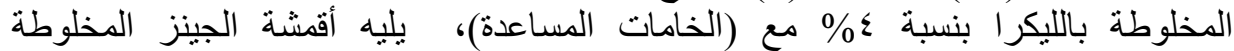

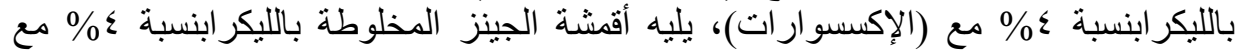

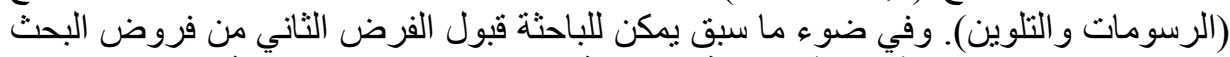

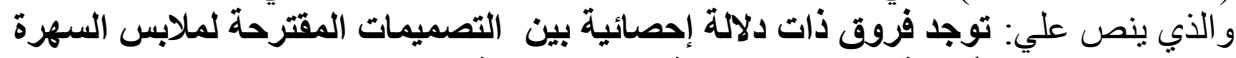

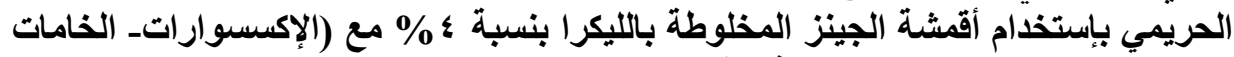

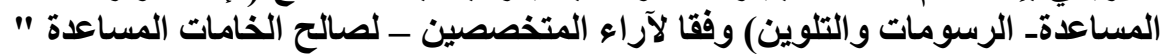

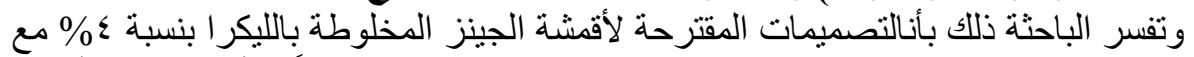

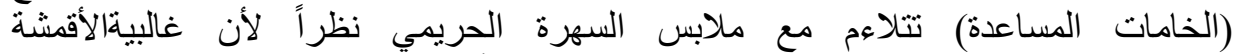

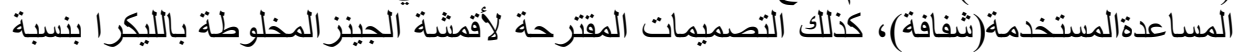

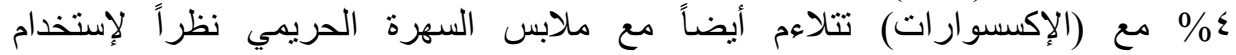

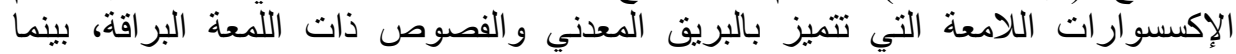

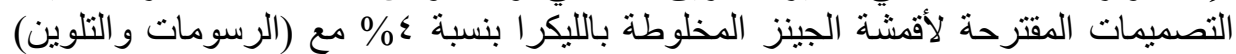

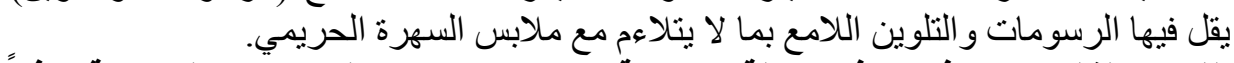

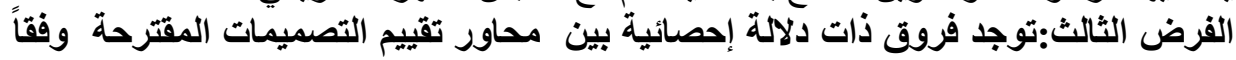

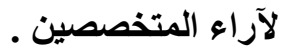
للأتحقق من هذا الفرض تم حساب تحليل التباين لمتوسط محاور تقييم التصميمات المنفذة وفقاً لآر اء المتخصصين وجدول (ع ا ) يوضح ذللك: 
مجلة الاقتصاد المنزلي - مجلد 7 r- العدد الثالث-r 1 ـ بم

جدول ( \& 1) تحليل التباين لمتوسط تقييم التصميمات المقترحة وفقاً لآراء المتخصصين

\begin{tabular}{|c|c|c|c|c|c|}
\hline الالالة & قيمة "ف" & متوسط المربعات & درجة الحرية & مجموع المربعات & محاور التقييم \\
\hline \multirow{3}{*}{$\because \cdot r}$. & \multirow{3}{*}{$r .071$} & $0 r .01 \mathrm{~V}$ & $r$ & $1 \cdot V_{.} \cdot r r$ & بين المجمو عات \\
\hline & & $1 \leqslant .991$ & IVV & YTO\&.VIV & داخل المجموعات \\
\hline & & & $1 \times 9$ & YVTI.VO. & المجموع \\
\hline
\end{tabular}

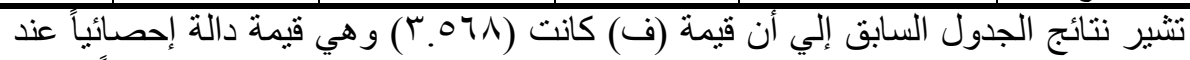

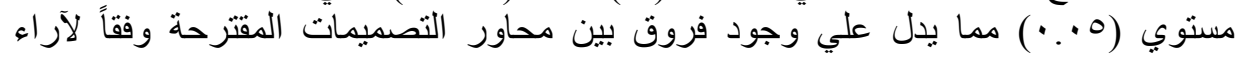

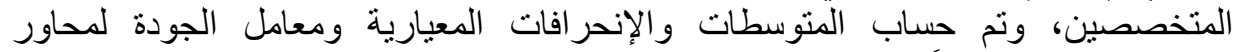

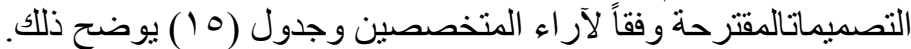

جدول (0 1 ) المتوسطات والإنحر افات المعيارية ومعامل الجودة لأل المحاور التصميمات

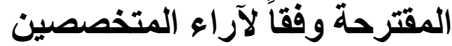

\begin{tabular}{|c|c|c|c|c|}
\hline ترتيب المحاور & معامل الجودة & الإنحراف المعياري & المتوسط & المحور \\
\hline 1 & $97 . r Y$ & r.Ar & KV.OV & الجاتب الابتكاري \\
\hline $\bar{r}$ & $90 . V \mathrm{~V}$ & $r .19$ & rv.ro & الجانب الوظيفي \\
\hline$r$ & $91 . \wedge 1$ & 0.11 & ro.人r & الجاتب الجمالي \\
\hline
\end{tabular}

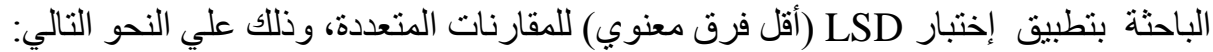

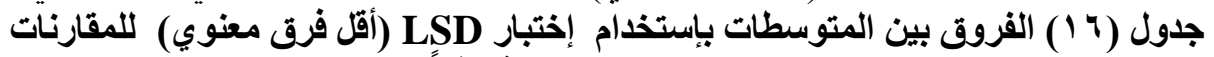

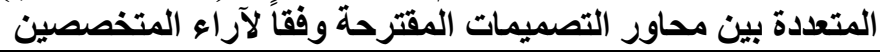

\begin{tabular}{|c|c|c|c|}
\hline الجاتب الجمالي & الجاتب الوظيفي & الجانب الإبتكاري & \\
\hline$* 1 . V r$ &.$Y 17$ & & الجانب الإبتكاري \\
\hline$* 1.01$ & & & الجانب الوظيفي \\
\hline & & & الجاتب الجمالي \\
\hline
\end{tabular}

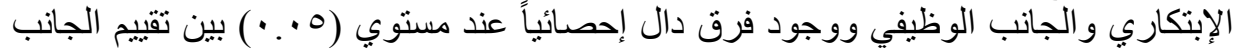

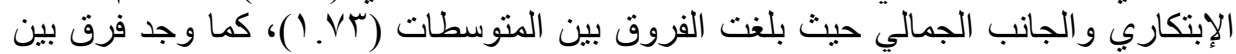

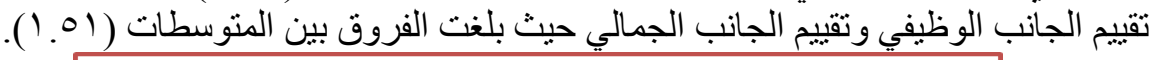

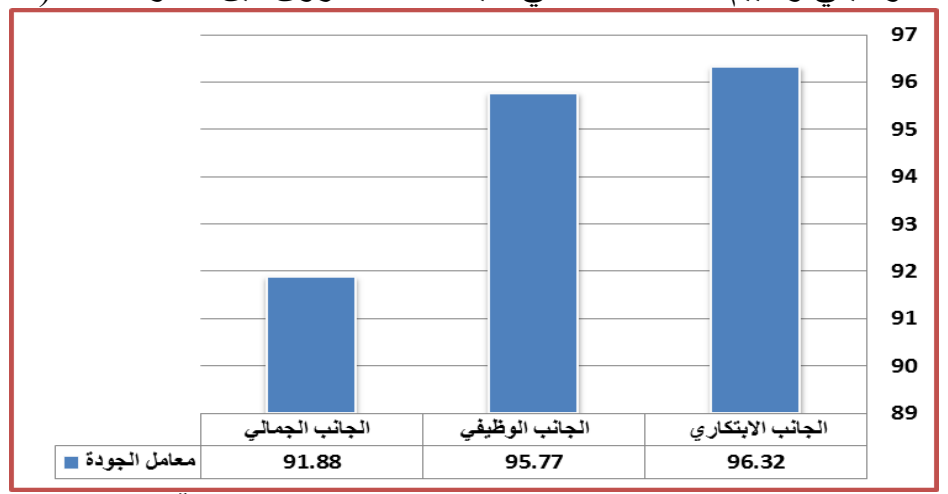

شكل (r) معامل الجودة لتقييم محاور التصميمات المقترحة وفقاً لآراء المتخصصين 


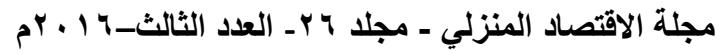

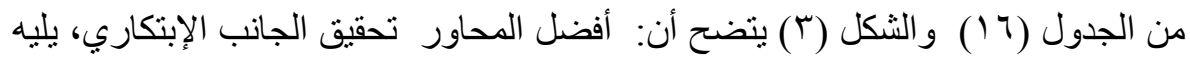

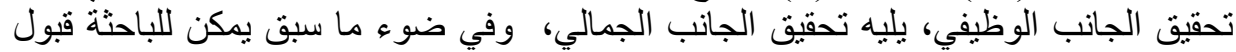

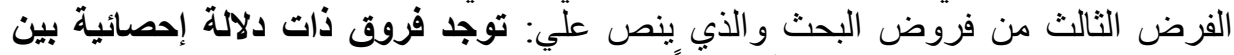

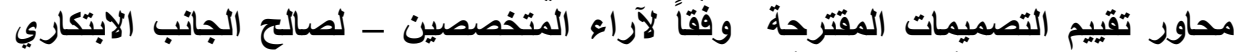

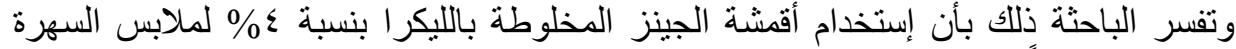

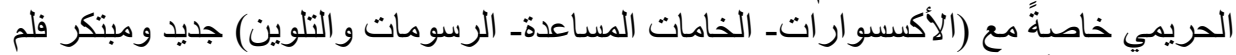

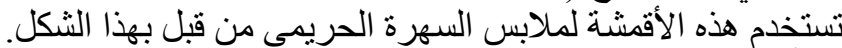

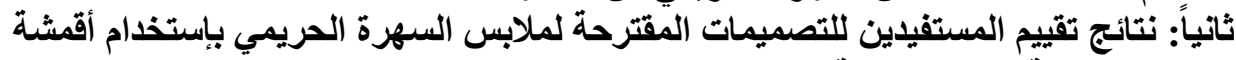

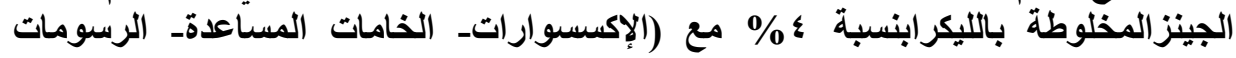

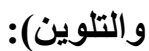
الفرض الأول: توجد فروق ذات دلالة إحصائية بين التصميمات المقترحة في تحقيق جوانب

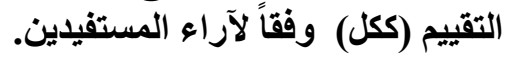

جدول (IV) متوسطات تقييمات المستفيدين لمحاور التقييم (ككل) للتصميمات المقترحة

\begin{tabular}{|c|c|c|c|c|c|c|c|c|c|c|c|c|c|}
\hline \multicolumn{4}{|c|}{ المقترح الثالث } & \multicolumn{4}{|c|}{ المقترح حاثثاني } & \multicolumn{4}{|c|}{ المقترح الاول } & \multirow[b]{2}{*}{ المؤشر } & \multirow[b]{2}{*}{ الجاتب } \\
\hline التصميم (i) & التصميم & $\begin{array}{l}\text { التصمي) } \\
\text { (1.) }\end{array}$ & 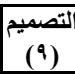 & تصميج & $\begin{array}{l}\text { آلتصمئ (v) } \\
\text { (v) }\end{array}$ & أنتصميم & تصني & التصمي & التصميم & التصميم) & (1) (1) & & \\
\hline ir. & ir. & ir. & ir. & ir. & ir. & ir. & $1 \%$. & ir. & ir. & ir. & ir. & | كماش الدماشيم & الابتكاتب \\
\hline ir. & ir. & ir. & ir. & ir. & ir. & ir. & ir. & ir. & ir. & ir. & ir. & 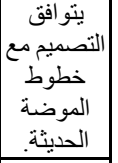 & \\
\hline ir. & ir. & ir. & ir. & ir. & ir. & ir. & ir. & ir. & ir. & ir. & ir. & | لملى التجديد & \\
\hline ir. & ir. & ir. & ir. & ir. & ir. & ir. & $1 \%$. & ir. & ir. & ir. & ir. & |لها أفميار & \\
\hline ir. & ir. & 110 & A. & ir. & re. & ir. & A. & ir. & ir. & ir. & ir. & 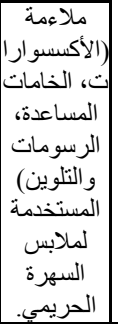 & \\
\hline
\end{tabular}




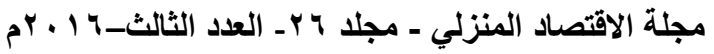

\begin{tabular}{|c|c|c|c|c|c|c|c|c|c|c|c|c|c|}
\hline ir. & ir. & 110 & $1 \%$. & ir. & ir. & Ir. & A. & ir. & ir. & ir. & Ir. & التصناسي & الوظيفي \\
\hline ir. & ir. & Ir. & ir. & ir. & ir. & Ir. & ir. & ir. & Ir. & ir. & A. & الترحقة. & \\
\hline ir. & ir. & Ir. & $1 \%$. & ir. & ir. & ir. & ir. & ir. & ir. & ir. & ir. & البنمولةمي & \\
\hline ir. & ir. & Ir. & ir. & ir. & ir. & Ir. & ir. & ir. & ir. & ir. & A. & على التصميحة & \\
\hline Ir. & ir. & Ir. & A. & ir. & ir. & Ir. & ir. & ir. & ir. & ir. & $i r$. & 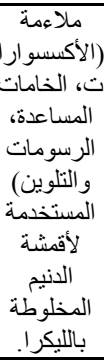 & \\
\hline ir. & ir. & A. & ir. & ir. & ir. & Ir. & $1 \ldots$ & ir. & ir. & $r r$ & ir. & اللنصلى العام. & الجماني \\
\hline $1 \%$. & ir. & A. & ir. & ir. & ir. & Ir. & $1 \ldots$ & ir. & ir. & $1 r$. & ir. & التين أجزانب. & \\
\hline 11. & 11. & Ir. & 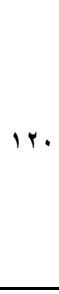 & ir. & ir. & Ir. & ir. & ir. & ir. & $r r$ & ir. & تلمالميميلت & \\
\hline A. & A. & A. & ir. & ir. & ir. & Mr. & $1 \ldots$ & ir. & ir. & $1 T$. & $1 T$. & الالألمان في & \\
\hline A. & A. & A. & ir. & 110 & 110 & A. & ir. & v. & A. & A. & $1 \%$. & 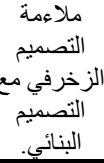 & \\
\hline
\end{tabular}


للتحقق من هذا الفرض نم حساب تحليل التباين لمتوسط التصميمات المقترحة في تحقيق

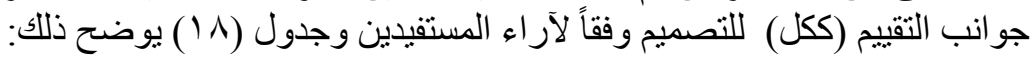

جدول (1 ا ) تحليل التباين لمتوسط التصميمات المقترحة في تحقيق جوانب التقييم (ككل) وفقاً لآراء المستفيدين

\begin{tabular}{|c|c|c|c|c|c|}
\hline الدلالة & قيمة "ف" & متوسط المربعات & درجة الحرية & مجموع المربعات & جوانب التقييم \\
\hline \multirow{3}{*}{$\because$ ג } & \multirow{3}{*}{ 1.rAT } & $19 . .10 Y$ & 11 & $r .91 .74 \mathrm{~V}$ & بين المجمو عات \\
\hline & & $1 \leqslant \Lambda . T Y \leqslant$ & 171 & $r \Sigma q . r . r T r$ & داخل المجموعات \\
\hline & & & $1 \times 9$ & $r 7990 \ldots$ & المجموع \\
\hline
\end{tabular}

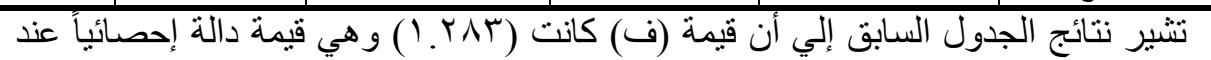

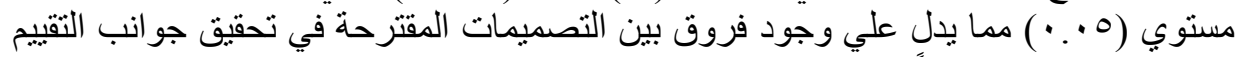

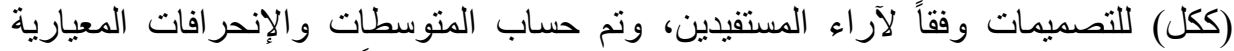

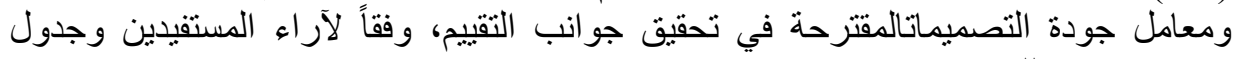
(19) (19) يوضح ذلك جودة

جدول (9 1 ) المتوسطات والإنحرافات المعيارية ومعامل الجودة للتصميمات المقترحة في تحقيق جوانب التقييم (ككل) وفقاً لآراء المستقيدين

\begin{tabular}{|c|c|c|c|c|c|}
\hline التصميمات & معامل الجودة & الإنحراف & المتوسط & التصميمات & ألانيتخدام أقمشة المخليكة \\
\hline$\varepsilon$ & 90.07 & $1 \leq . V$ & $11 \varepsilon .7 V$ & التصميم 1 & \multirow{4}{*}{ الإكسسوارات } \\
\hline r & $9 \vee . \vee \wedge$ & $1 \cdot r \mu$ & IV.rT & التصميم Y & \\
\hline r & $9 \vee . \vee \wedge$ & I. IT & IIV.rT & التصميم با & \\
\hline$r$ & QV.YY & 14.91 & 117.78 & التصميم ؛ & \\
\hline 7 & $9 \leqslant . \leqslant \leqslant$ & Ir.rs & נוT.T & التصميم ه & \multirow{4}{*}{ الخامات المساعدة } \\
\hline$r$ & $9 \vee . \vee \wedge$ & I.rT & IIV.r & التصميم 7 & \\
\hline 1 & $99 . V Y$ & 1.19 & $119.7 \mathrm{~V}$ & التصميم V & \\
\hline 1 & $99 . V Y$ & 1.19 & 119.78 & التصميم ^ & \\
\hline V & 91.11 & $1 \varepsilon . \wedge 7$ & 1.9.r & التصميم 9 & \multirow{4}{*}{ الرسومات والتلوين } \\
\hline$\Lambda$ & $9 . .07$ & $1 V .9 V$ & $1 \cdot 1.7 \mathrm{~V}$ & التصميم · & \\
\hline 0 & $90 .$. & $1 \leq . \varepsilon$ & $11 \varepsilon .$. & التصميم 11 & \\
\hline 0 & $90 .$. & $1 \leqslant . \cdot \varepsilon$ & $11 \leq .$. & التصميم r 1 & \\
\hline
\end{tabular}

ولتأكيد دلالة الفروق بين التصميمات المقترحة في ضوء آراء آراء المستفيدين قامت الباحثة

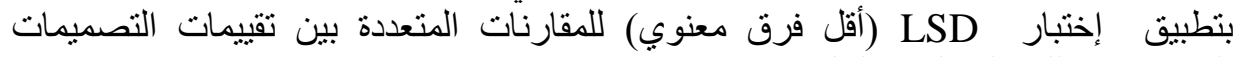
المقترحة، وذللك علي النحو التالي: 


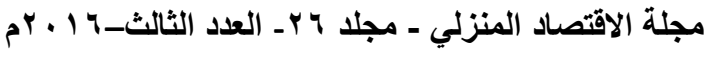

جدول (· r ) الفروق بين المتوسطات بإستخدام إختبار LSD (أقل فرق معنوي) للمقارنات

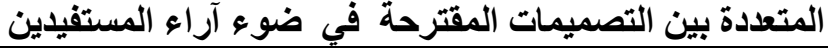

\begin{tabular}{|c|c|c|c|c|c|c|c|c|c|c|c|c|}
\hline أتصميم & التصميم) & التصميم (1) & (9) التصميم & التصميم & $\begin{array}{c}\text { التصميم) } \\
\text { (V) }\end{array}$ & التصميم & ألتصميم) & أتصميم & التصميم & ألتصميم) & التصميم (1) & \\
\hline. $.7 \mathrm{~V}$ & $\therefore$. TV & $* 7 .$. & *0.rT & *o... & $* 0 .$. & Y.TV & $1 . r 4$ & r... & Y.TV & Y.TV & & التصميم 1 \\
\hline ז.r. & ז.ז & *^. TV & $* \wedge .$. & T.rT & זT. & $\because \cdots$ & $* \varepsilon \ldots$ & $\cdot .7 \mathrm{~V}$ & $\because \cdots$ & & & التصميم Y \\
\hline r.ru & r.ru & *^.TV & $*$ *1.. & T. Tा & זT.ז & $\because \cdots$ & * $\ldots .$. &.. $\mathrm{TV}$ & & & & التصميم بَ \\
\hline T.TV & T.TV & *^... & *V.rT & r... & $r .$. & $\cdot .7 \mathrm{~V}$ & r.ru & & & & & التصميم ؛ \\
\hline$\cdot . \mathrm{TV}$ & $\cdot .7 \mathrm{~V}$ & *ย.TV & $* \varepsilon \ldots$ & *4. & *7. & *£... & & & & & & التصميم • \\
\hline ז.ז. & ז.ז. & *^.TV & $* \wedge .$. & T.זT & ז.ז & & & & & & & التصميم 7 \\
\hline *0.7V & *0.TV & $* 11 .$. & $* 1 \cdot . r T$ & $\because \cdots$ & & & & & & & & التصميم V \\
\hline *0.7V & *0.TV & $* 11 .$. & $* 1 \cdot . r \mu$ & & & & & & & & & التصميم 1 \\
\hline *ะ.TV & $* \varepsilon . T V$ & $\cdot .7 \mathrm{~V}$ & & & & & & & & & & التصميم 9 \\
\hline *0.rr & 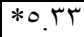 & & & & & & & & & & & التصميم • 1 \\
\hline$\because \cdots$ & & & & & & & & & & & & التصميم 11 \\
\hline & & & & & & & & & & & & التصميم Y 1 \\
\hline
\end{tabular}

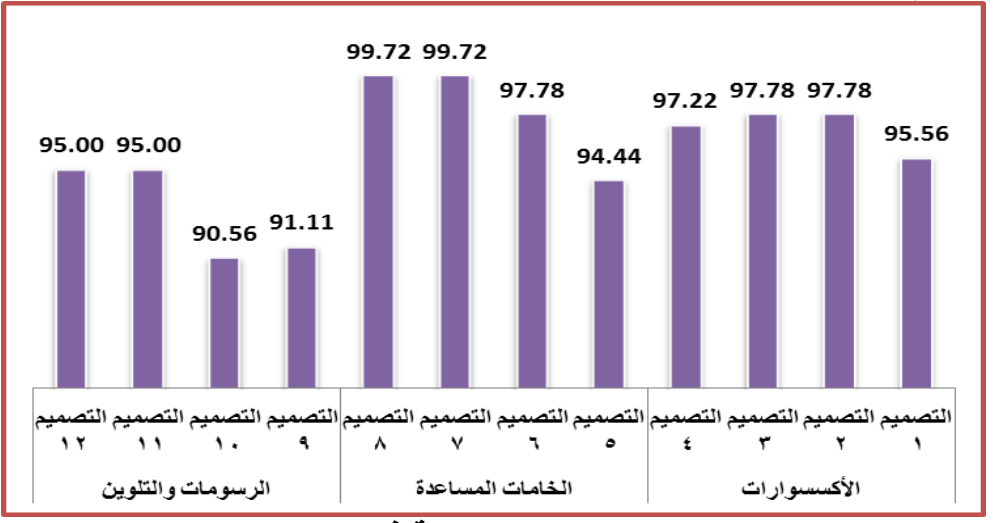

شكل (؛ )معامل الجودة للتصميمِات المقترحة في تحقيق جوانب التقييم (ككل)

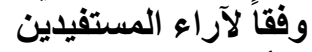

من الجدول (•r) و الثكل (ع) يتضح أن:

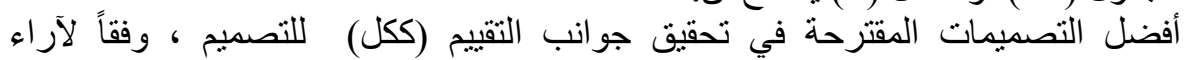

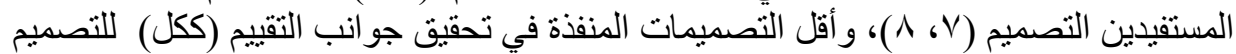

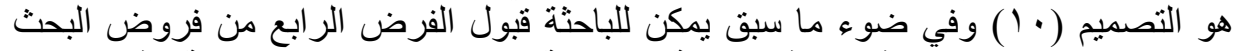

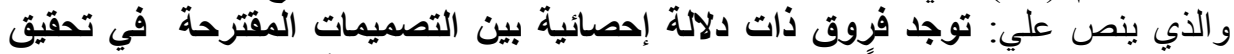

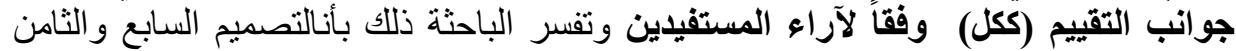

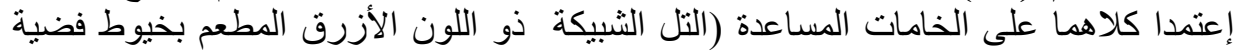

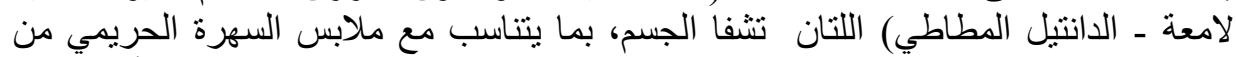

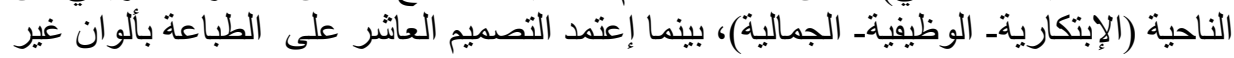

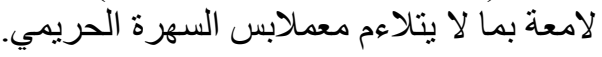


الفرض الثاني: توجد فروق ذات دلالة إحصائية بين التصميمات المقترحة لملابس السهرة

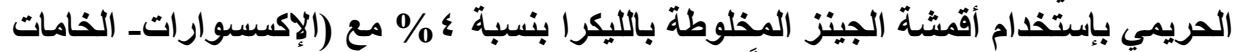

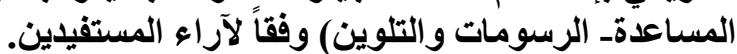

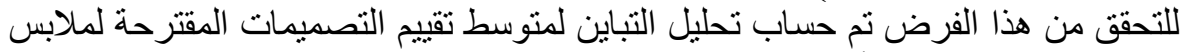

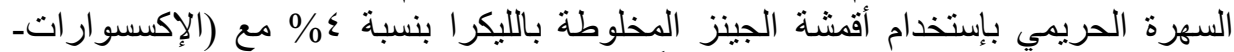

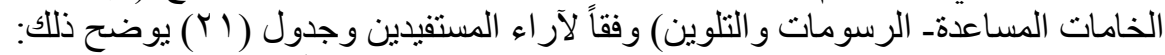

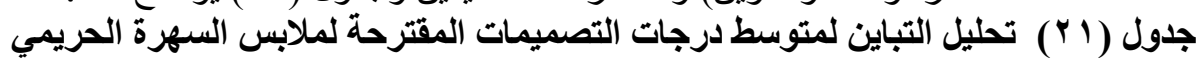

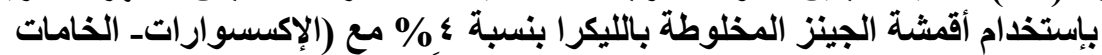

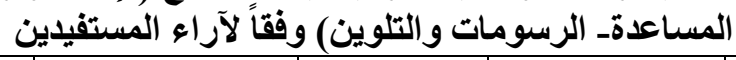

\begin{tabular}{|c|c|c|c|c|c|}
\hline الالالة & قيمة "ف" & متوسط المربعات & درجة الحرية & مجموع المربعات & محاور التقييم \\
\hline \multirow{3}{*}{$\because .17$} & \multirow{3}{*}{$\varepsilon .(7)$} & $\pi r \cdot \ldots$ & $r$ & Ir $\{. \cdots$ & بين المجموعات \\
\hline & & $1 \leqslant 0.0 .1$ & IVV & rovo0... & داخل المجموعات \\
\hline & & & 189 & r $9990 . .$. & المجموع \\
\hline
\end{tabular}

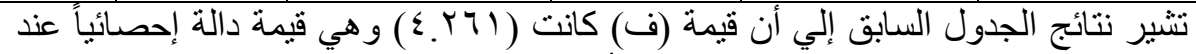

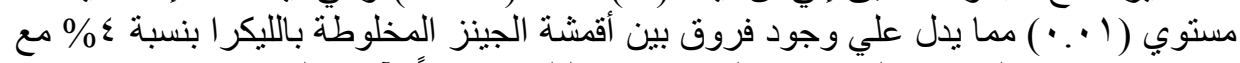

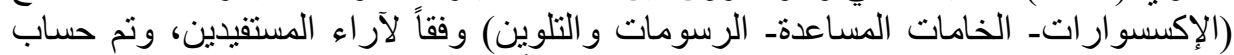

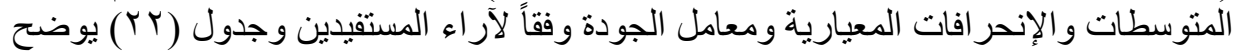

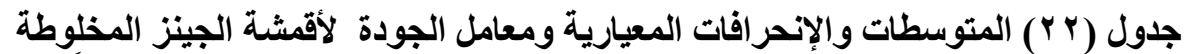

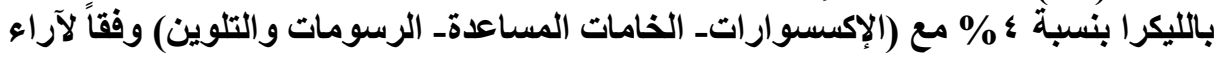
المستفيدين

\begin{tabular}{|c|c|c|c|c|}
\hline ترتيب المحاور & معامل الجودة & الإنحراف المعياري & المتوسط & أققشة الانيم المخلوطة بالليكرا \\
\hline$r$ & $9 v_{.} \cdot \wedge$ & 11.24 & 117.00 & الإكسسوارات \\
\hline$T$ & $9 V .94$ & $\Lambda . \mu 1$ & 118.0. & الخامات المساعدة \\
\hline$r$ & 94.94 & $10.1 \%$ & 111.0. & الرسومات و التلوين \\
\hline
\end{tabular}

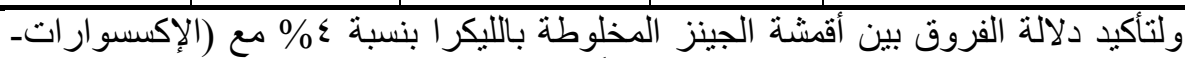

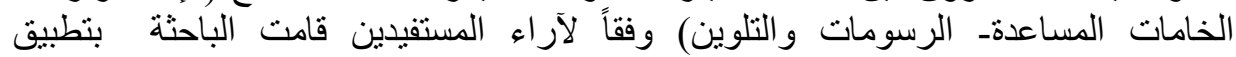

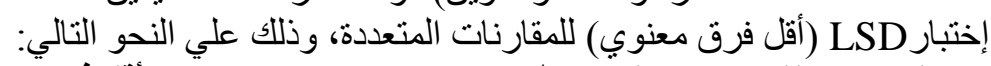

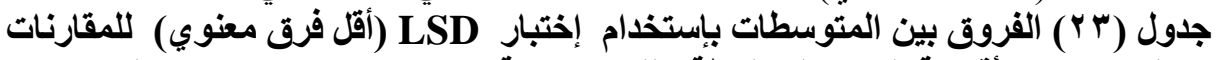

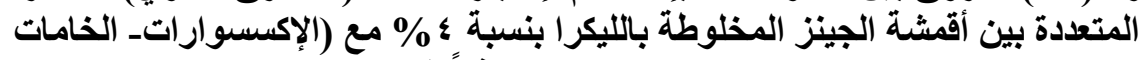

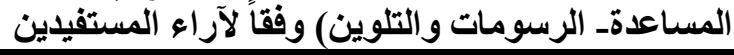

\begin{tabular}{|c|c|c|c|}
\hline الرسومات والتلوين & الخامات المساعدة & الإكسسوارات & \\
\hline$* 0 . \ldots$ & $* 1 \ldots$ & & الإكسسوار ات \\
\hline$* 7 .$. & & & الخامات المساعدة \\
\hline & & & الرسومات والتلوين \\
\hline
\end{tabular}

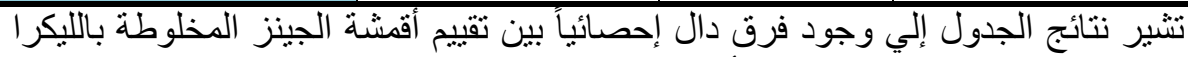

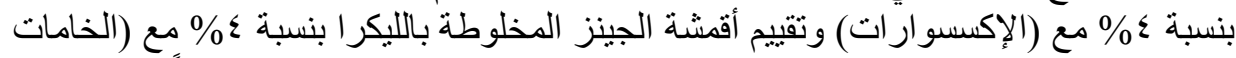

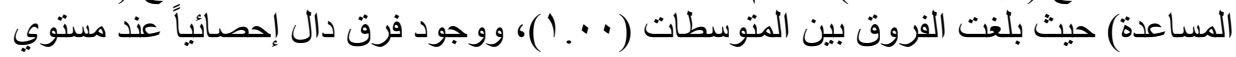




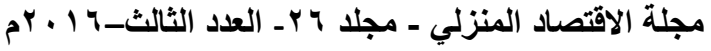

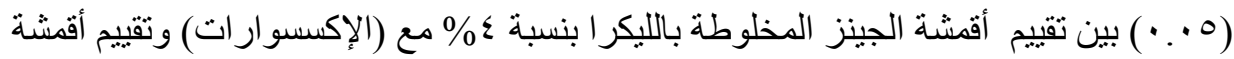

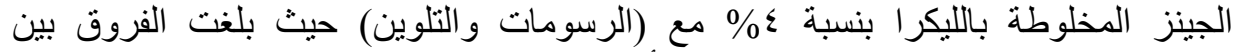

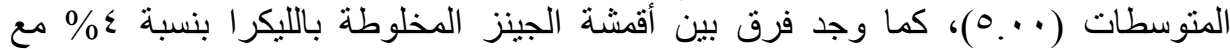

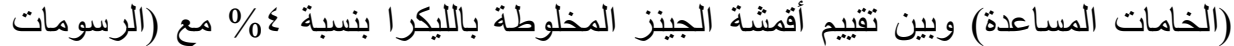

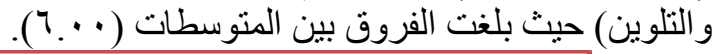

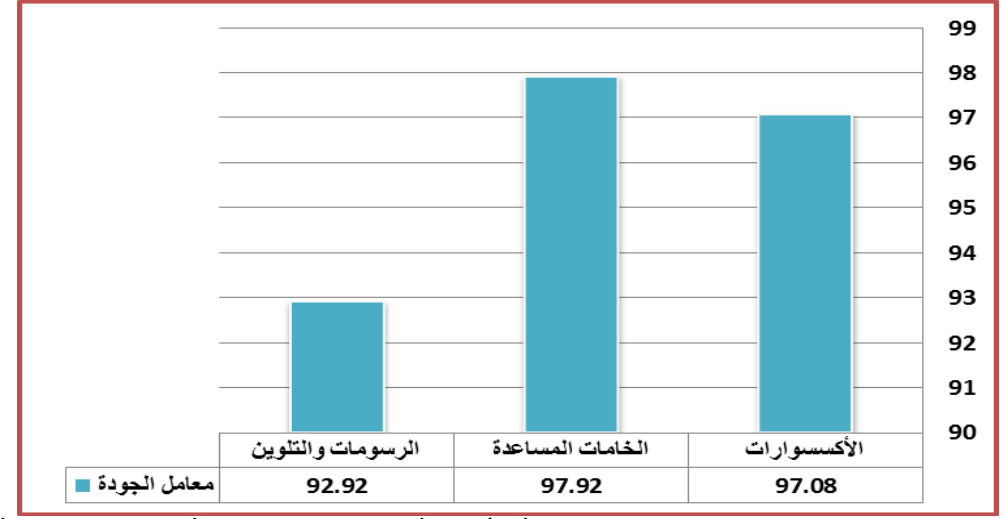

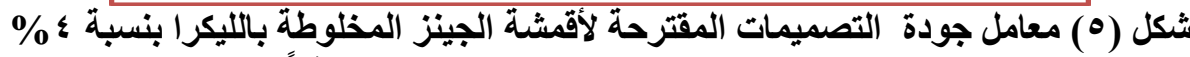

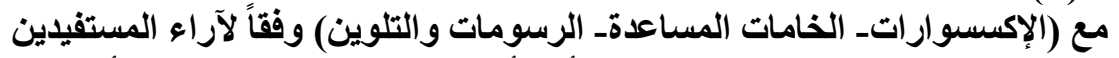

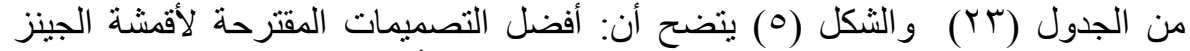

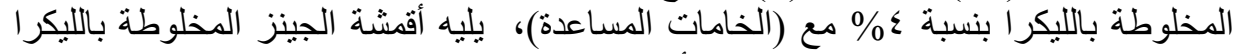

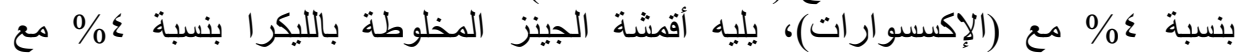

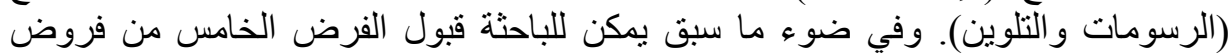

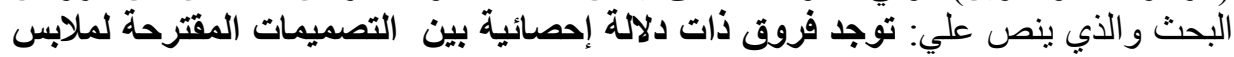

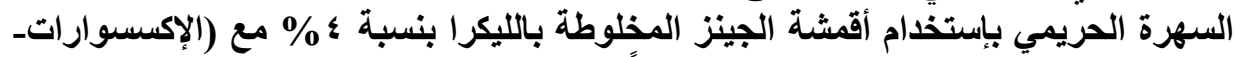

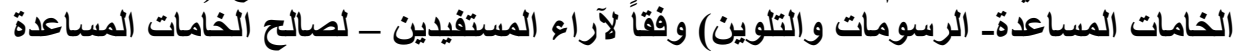

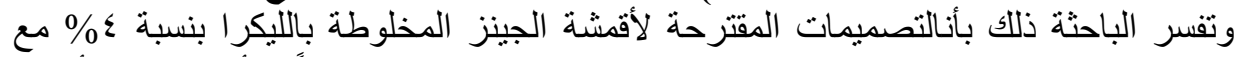

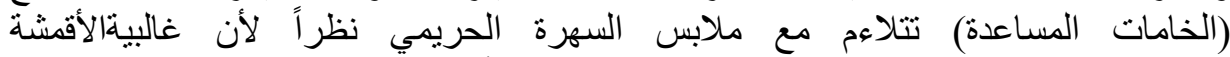

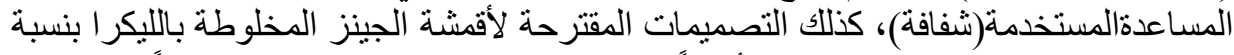

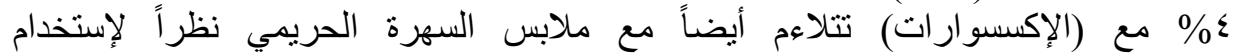

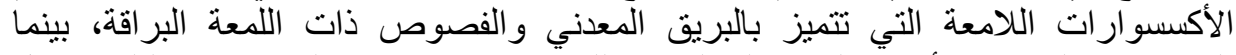

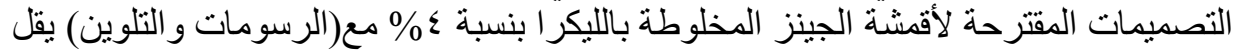

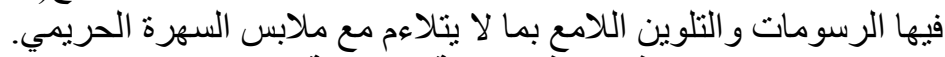

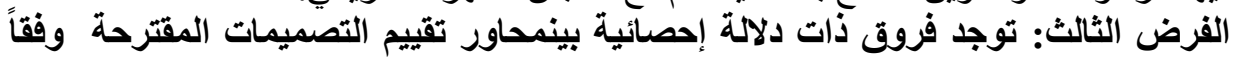
لآراء المستفيدين للأحقق من هذا الفرض تم حساب تحليل التباين لمتوسط محاور تقييم التصميمات المنفذة وفقاً

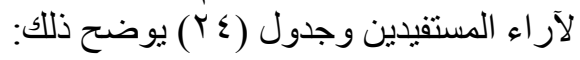




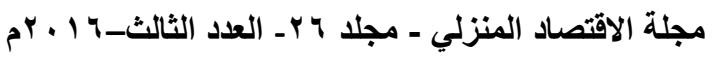

جدول ( \& Y) تحليل التباين لمتوسط تقييم التصميمات المقترحة وفقاً لآراء المستفيدين

\begin{tabular}{|c|c|c|c|c|c|}
\hline الالالة & قيمة "ف" & متوسط المربعات & درجة الحرية & مجموع المربعات & محاور التقييم \\
\hline \multirow{3}{*}{$\because \cdots 1$} & \multirow{3}{*}{ V.OYT } & $1.0 \mathrm{~V} .91 \mathrm{~V}$ & $r$ & rllo.Arr & بين المجموعات \\
\hline & & $1 \leqslant .07$. & IVY & YENVY.17V & داخل المجموعات \\
\hline & & & $1 \times 9$ & r7990.... & المجموع \\
\hline
\end{tabular}

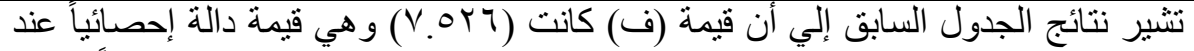

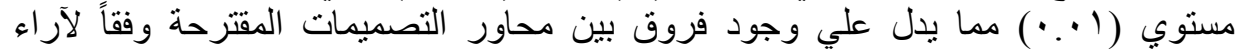

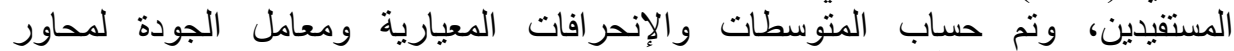

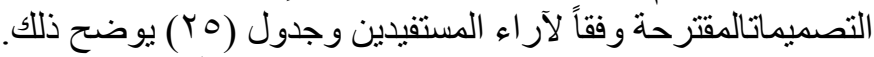

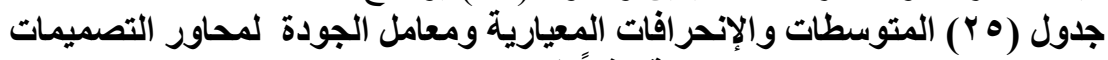

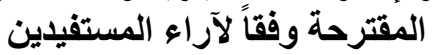

\begin{tabular}{|c|c|c|c|c|}
\hline ترتيب المحاور & معامل الجودة & الإنحراف المعياري & المتوسط & المحور - المور \\
\hline$r$ & $9 \vee . \vee 1$ & $\wedge .71$ & IIV.YO & الجانب الإبتكاري \\
\hline 1 & $91 . Y 4$ & $\Lambda . \wedge$. & $11 V .9 Y$ & الجاتب الوظيفي \\
\hline 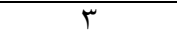 & $91.9 \xi$ & $17 . \leqslant \varepsilon$ & $11 \cdot . r \mu$ & الجاتب الجمالى \\
\hline
\end{tabular}

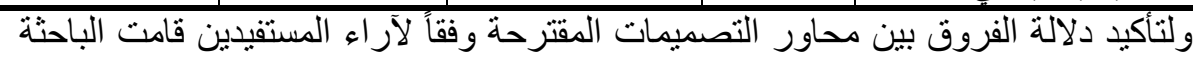

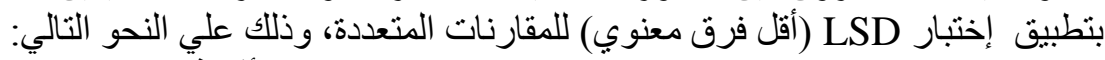

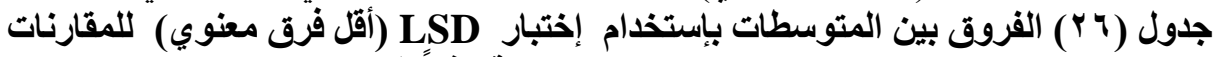

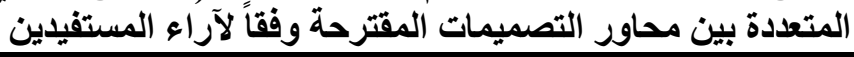

\begin{tabular}{|c|c|c|c|}
\hline الجانب الجمالي & الجانب الوظيفي & الجانب الإبتكاري & \\
\hline$* 7.91$ & .77 & & الجاتب الإبتكاري \\
\hline \multirow[t]{2}{*}{$V .01$} & & & الجاتب الوظيفي \\
\hline & & & الجانب الجمالي \\
\hline
\end{tabular}

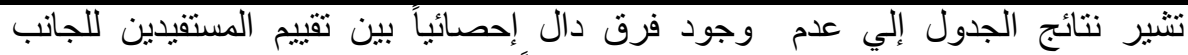

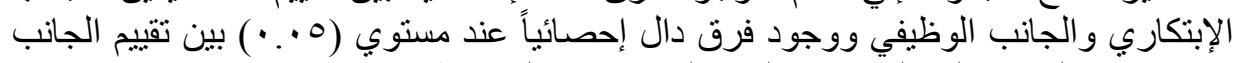

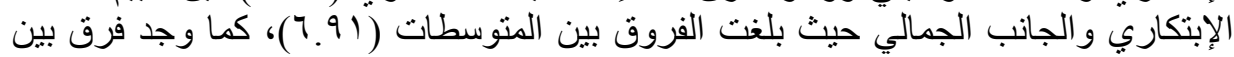

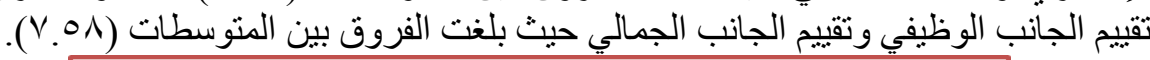

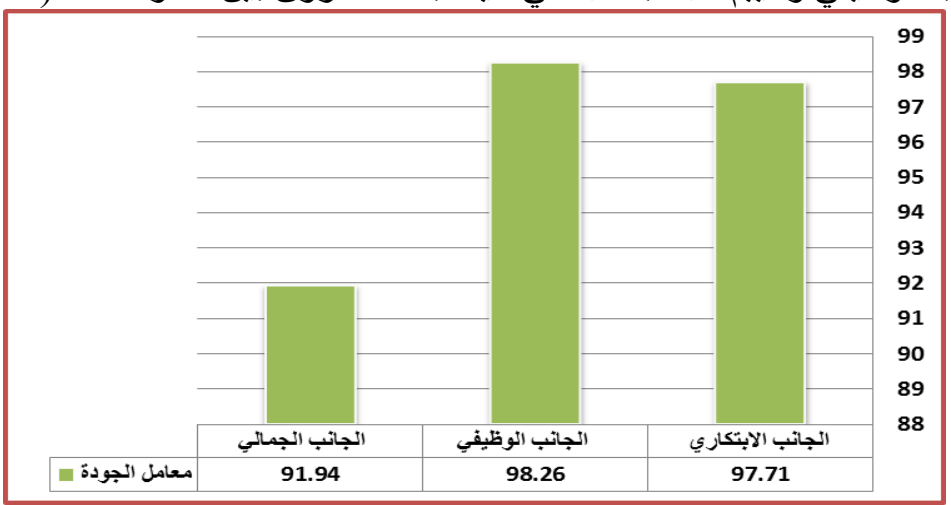

شكل (7) معامل الجودة لتقييم محاور التصميمات المقترحة وفقاً لآراء المستفيدين 


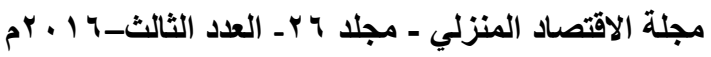

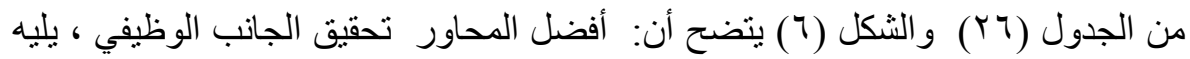

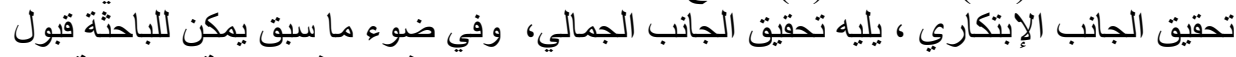

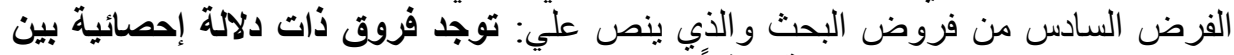

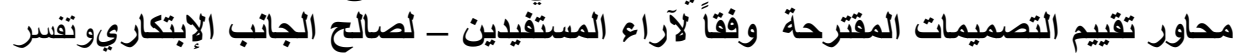

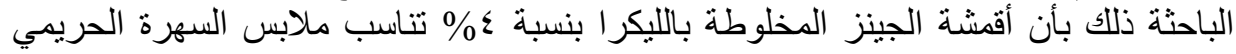

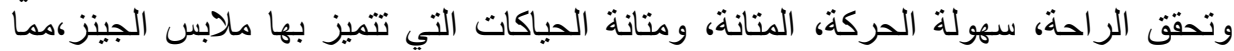

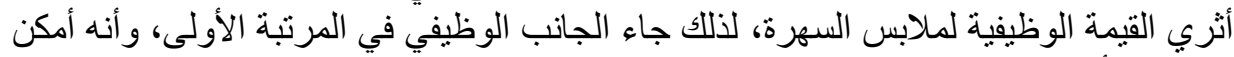

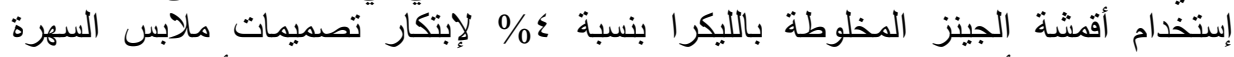

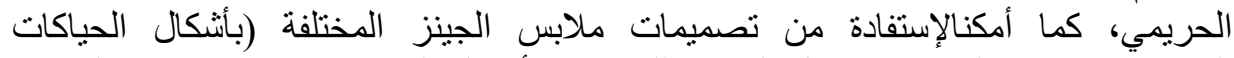

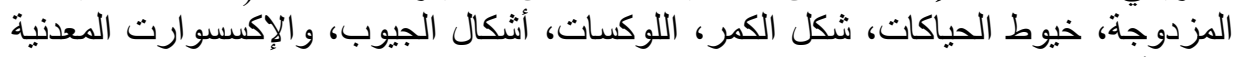

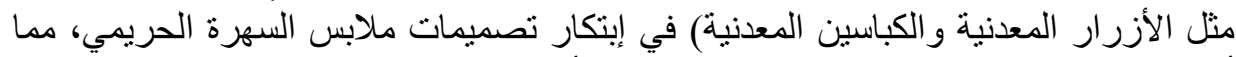

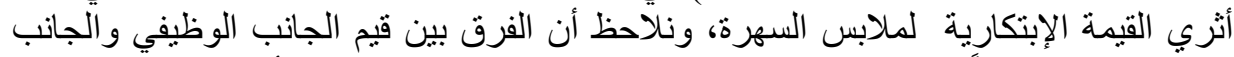

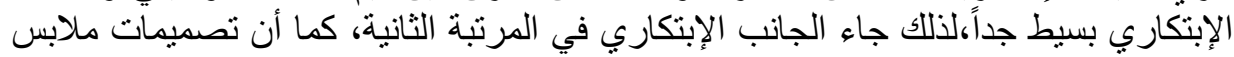

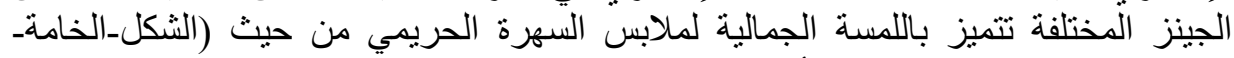

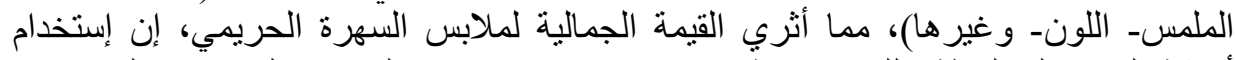

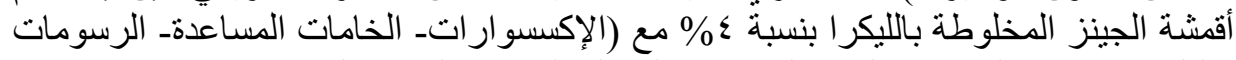

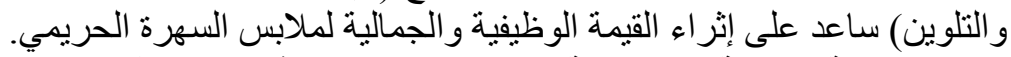

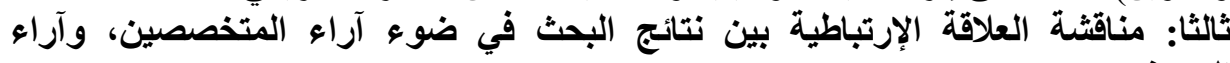

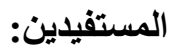
الفرض الأول: توجد علاقة إرتباطية بين ترتيب المتخصصين و ترتيب المستفيدين المينين

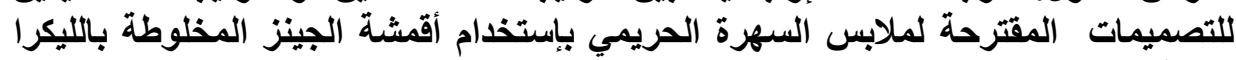

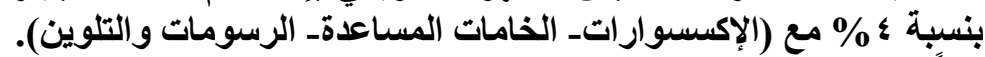
أولاً: ترتيب التصميمات الإكقوات المترحة قامت الباحثة بحساب معامل إرتباط الرتب لستبات لسبيرمان بين ترتيب (المتخصصين

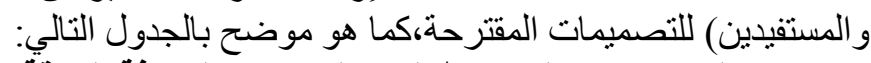

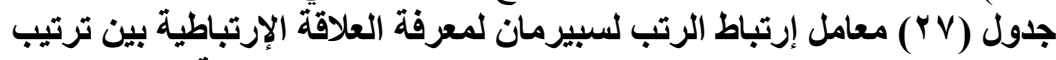

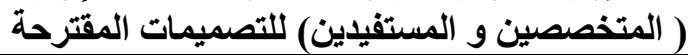

\begin{tabular}{|c|c|c|c|}
\hline معامل إرتباط الرتب لسبيرمان & ترتيب المستفادين & ترتيب المتخصصين & التصميمات \\
\hline \multirow{12}{*}{ 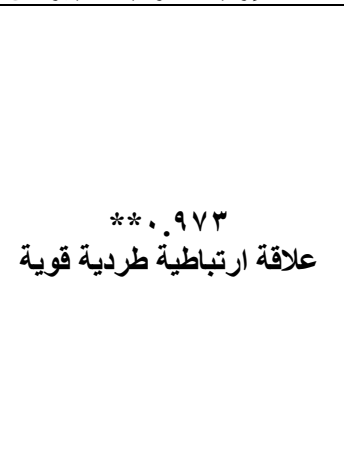 } & $\varepsilon$ & $r$ & التصميم 1 \\
\hline & r & 1 & التصميم r r \\
\hline & $r$ & 1 & التصميم بr \\
\hline & $r$ & $r$ & التصميم \& \\
\hline & 7 & 0 & التصميم • \\
\hline & $r$ & 1 & التصميم 7 \\
\hline & 1 & 1 & التصميم V \\
\hline & 1 & 1 & التصميم 1 \\
\hline & V & 7 & التصميم 9 \\
\hline & $\Lambda$ & V & التصميم • \\
\hline & 0 & $\xi$ & التصميم 11 \\
\hline & 0 & $\varepsilon$ & التصميم r I \\
\hline
\end{tabular}


تشير نتائج الجدول إلي أن: العلاقة الإرتباطية بين ترنيب كلاً من (المتخصصين

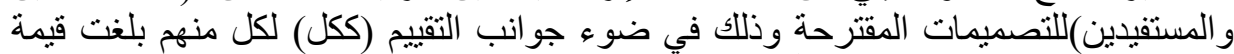

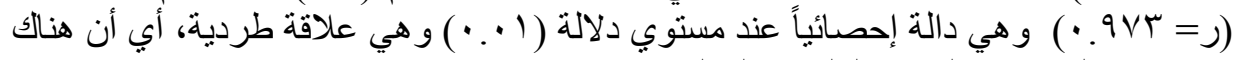
تو افق بين التقييم من الناحية العلمية و العين العملية. ثانيا:ترتيب المقترح من أقشثة الجينز المخلوطة بالليكرا بنسبة ؛ ؛

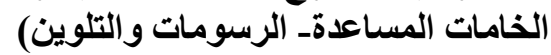

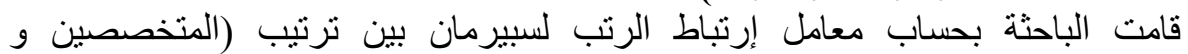

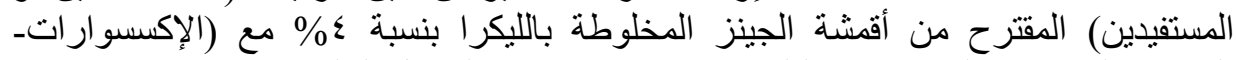

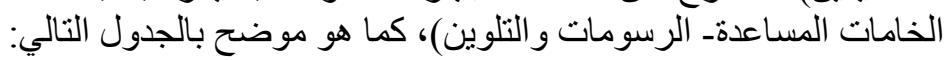

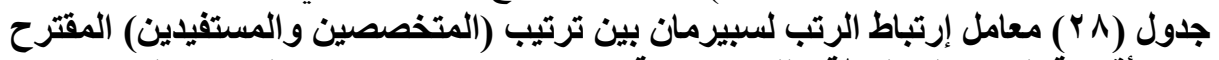

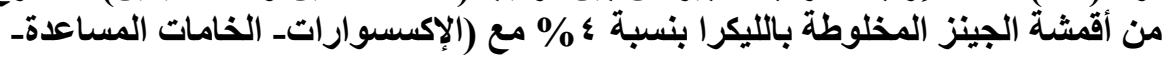

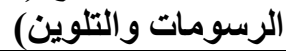

\begin{tabular}{|c|c|c|c|}
\hline معامل إرتباط الرتب لسبيرمان & ترتيب المستفادين & ترتيب المتخصصين & \\
\hline \multirow{3}{*}{ علاقة إرتباطية طردية تامة } & $r$ & $r$ & الإكسسوارات (1) \\
\hline & 1 & $T$ & الخامات المساعدة (Y) \\
\hline & $r$ & $r$ & الرسومات و التلوين (广) \\
\hline
\end{tabular}

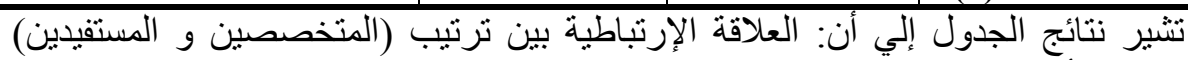

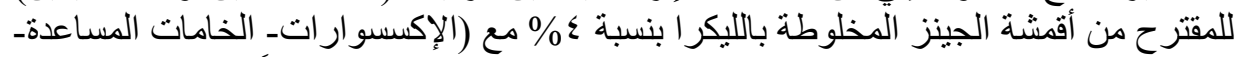

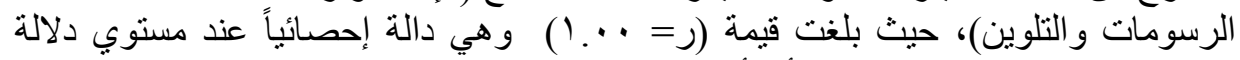

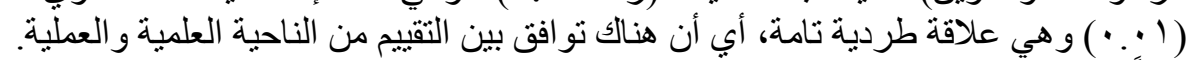
تُالثاً:ترتيب محاور التقيبيم ترتيب المحاور

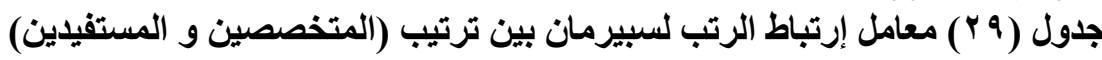

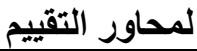

\begin{tabular}{|c|c|c|c|}
\hline معامل إرتباط الرتب لسبيرمان & ترتيب المستفادين & ترتيب المتخصصين & المحور \\
\hline \multirow{3}{*}{ علاقة إرتباطية طردية تامة } & $r$ & 1 & الجانب الإبتكاري (1) \\
\hline & 1 & $r$ & الجانب الوظيفي (Y) \\
\hline & $r$ & $r$ & الجانب الجمالى (r) \\
\hline
\end{tabular}

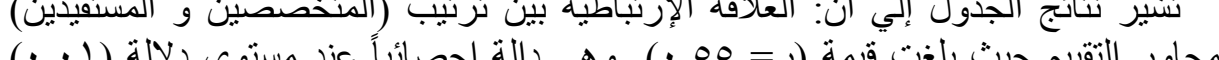

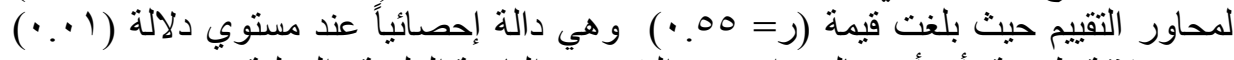

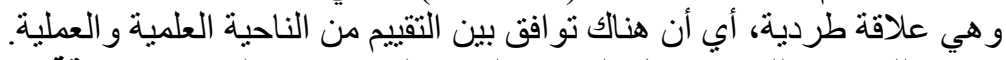

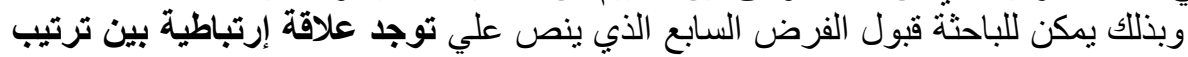

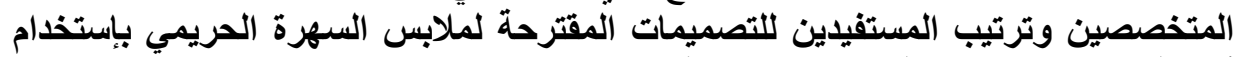

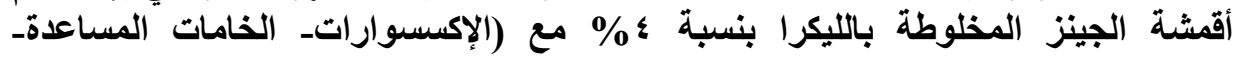
الرسومات و التلوين). 


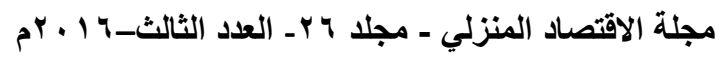

مستخلص النتائج:

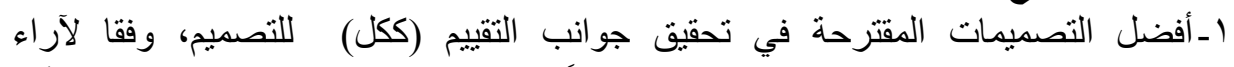

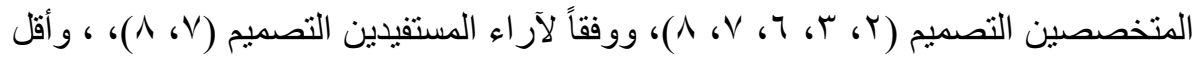

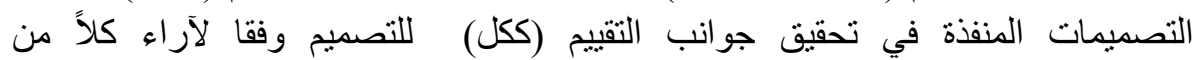

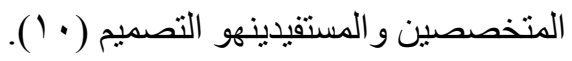

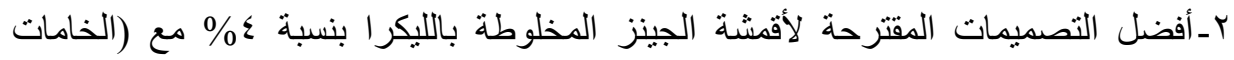

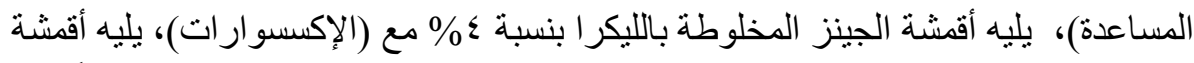

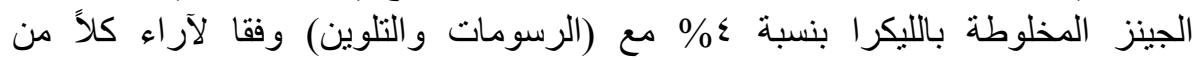

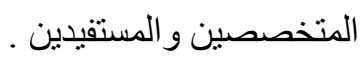

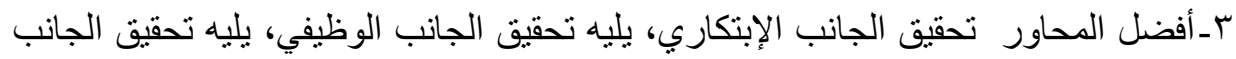

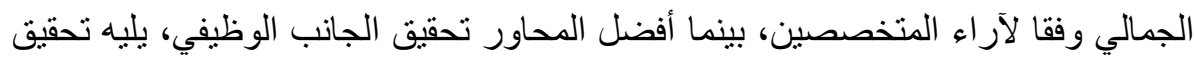

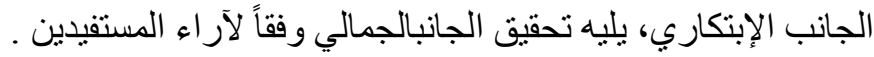

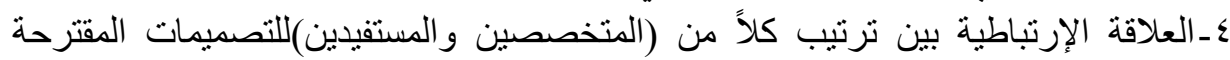

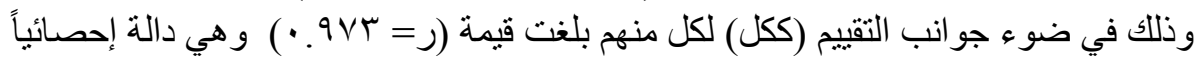

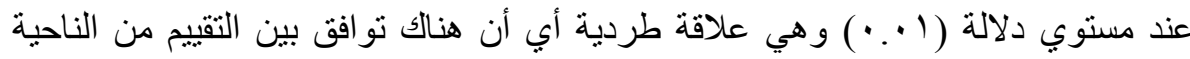
العلمية و العملية.

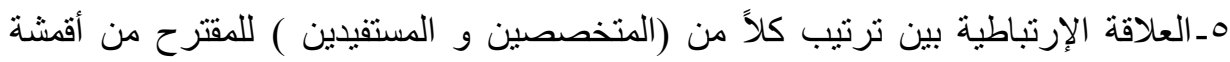

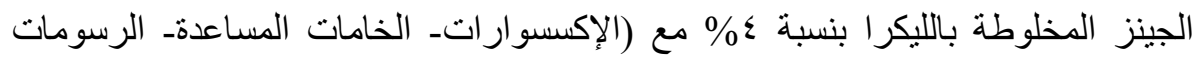

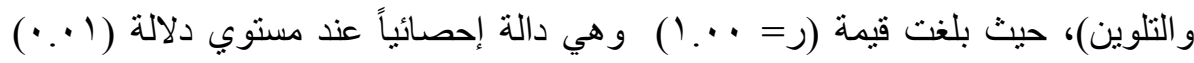

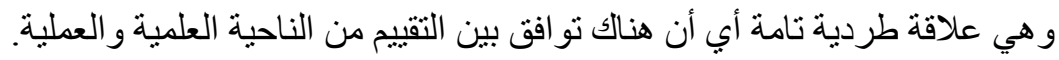

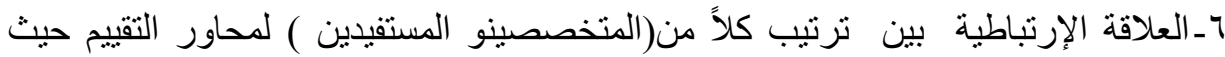

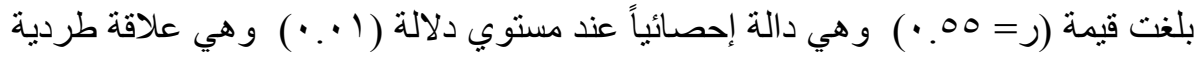
أي أن هناك تو افق بين التقييم من الناحية العلمية و العملية.

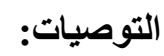

1 ـ الإستفادة من هذه الدر اسة بالكليات المتخصصة حتى تعم الفائدة على الطلاب.

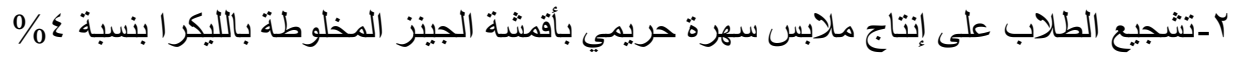

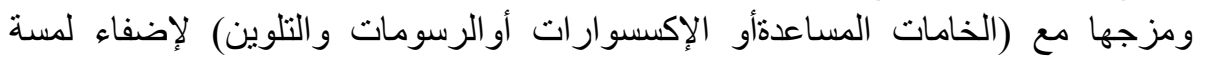

$$
\text { جمالية على هذه النوعية من المهلابس. }
$$

rـتثجيع مصانع الملابس الجاهزة على إنتاج ملابس سهرة حريمي بأقششة الجينز المخلوطة

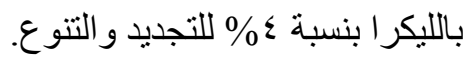
ع ـ عمل بحوث مقترحة لإبتكار تصميمات لملابس السهرة الحريمي مستخدماً لها أقمشة جديدة أخرى للتجديد و التنوع. 


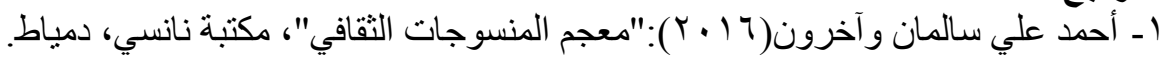

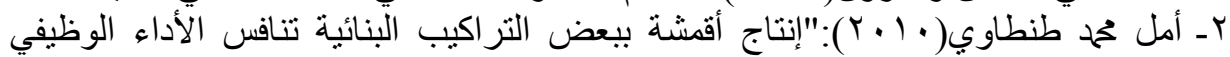

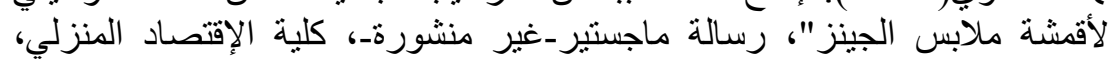
جامعة المنوفية.

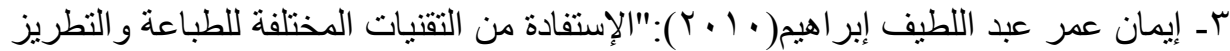

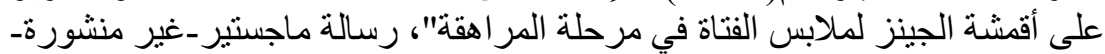

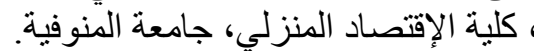

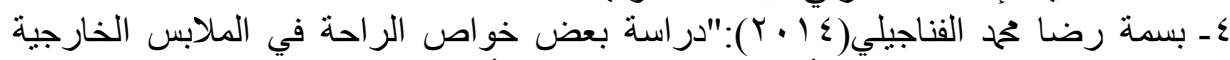

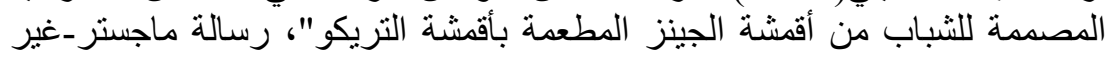

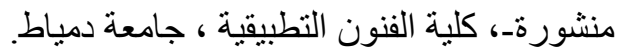

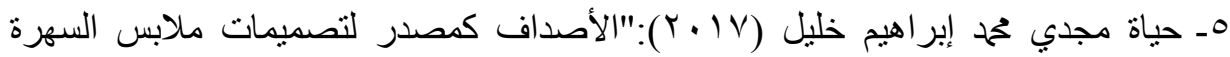

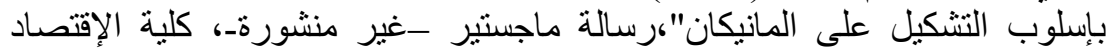

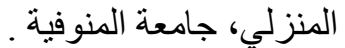

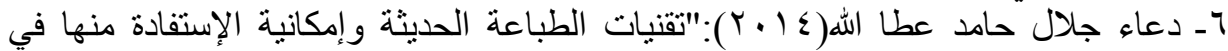

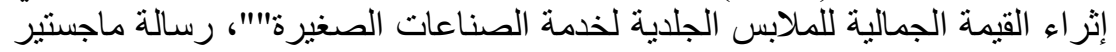

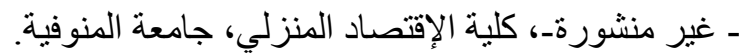

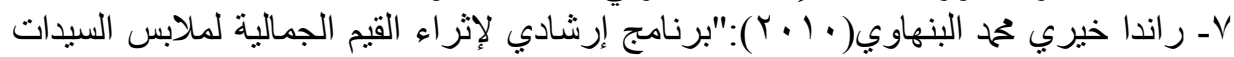

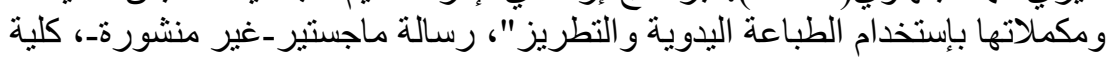
الإقتصاد المنزلي، جامعة المنوفية.

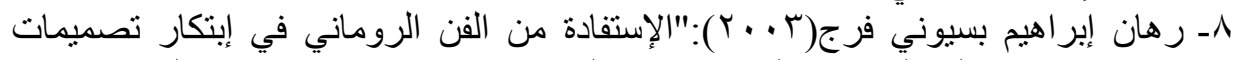

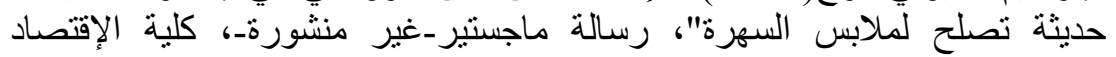

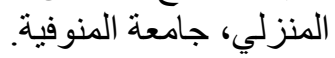

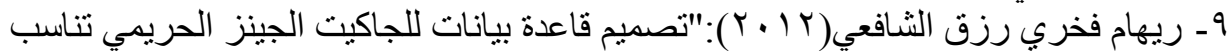

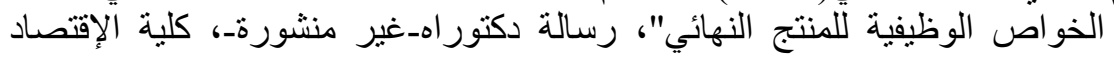
المنزلي، جامعة المنوفية.

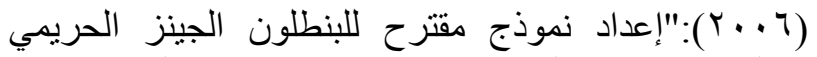
-1 .

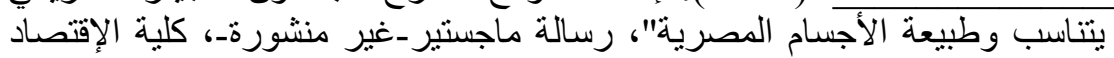

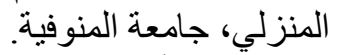

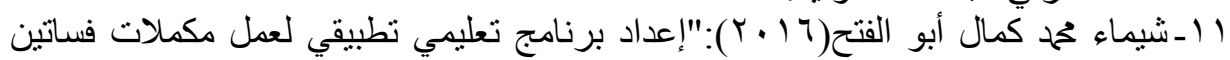

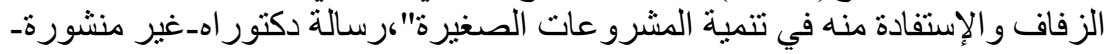

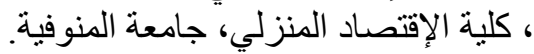

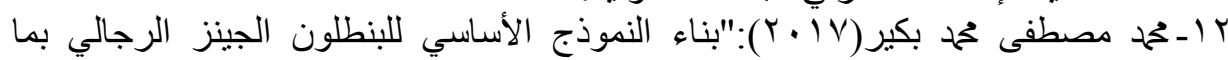

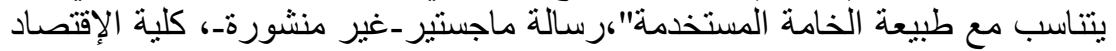

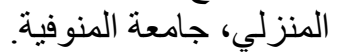

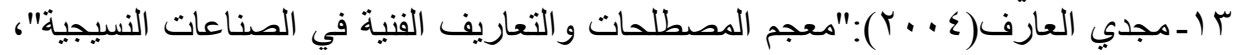
صندوق دعم صناعة الغزل والمنسوجات، الطبعة النعات الثالثة. 


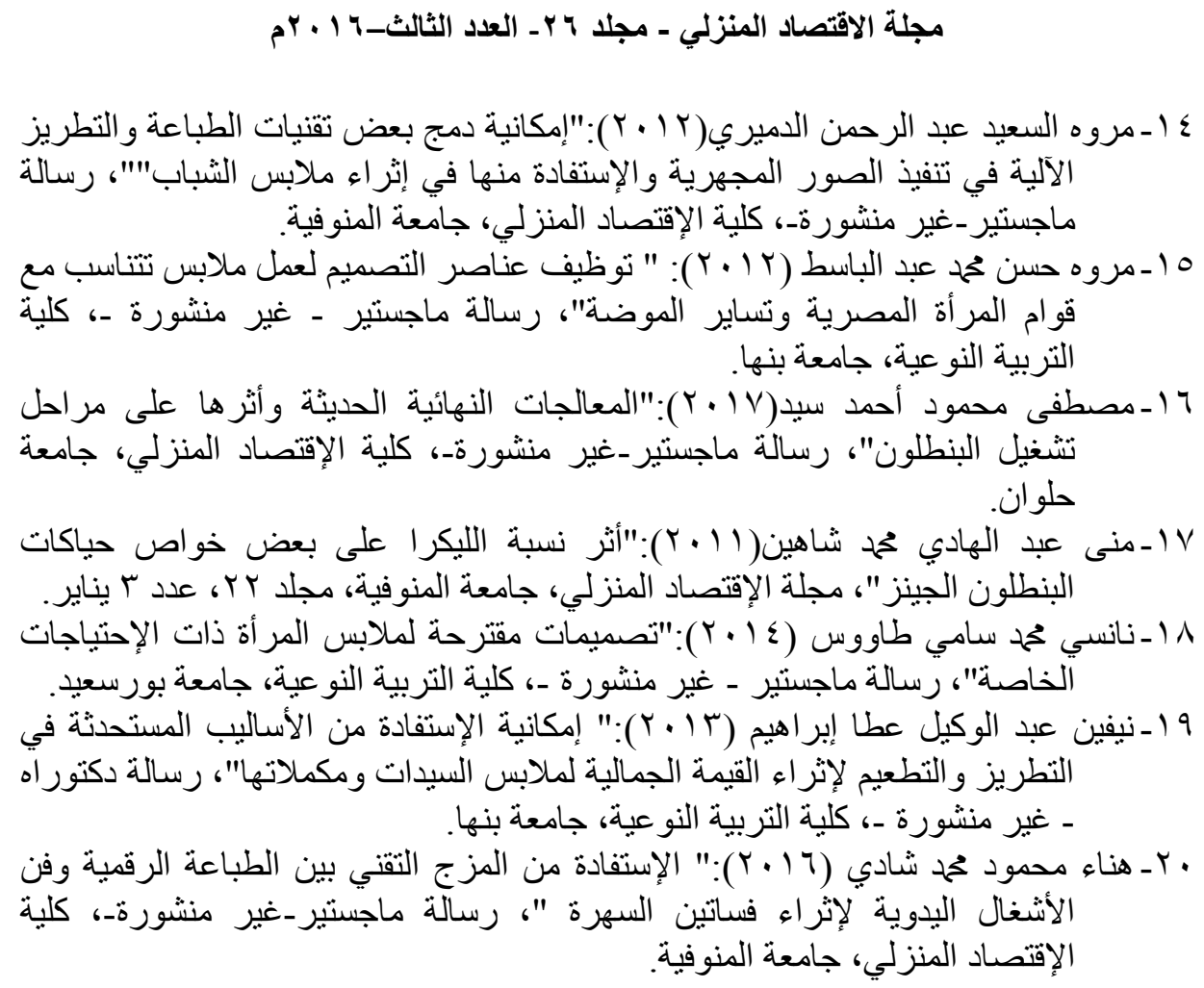

21- A Edwin Sunder, etal(2002),Asian Textile Journal, January, p. 53.

22- A. Gurarda, etal (2007): "The Effects of Elastane Yarn Type and Fabric Density Sewing Needle Penetration Forces and Seam Damage of PET/Elastane Woven Fabrics", Textile in Eastern Europe,October,vol. 15.

23- Gerlinde Gruber (2010):"The Master of the Blue Jeans", Galerie canesso, paris.

24-https:// www.Designboom.com/eng/education/denim2.html.

25-https://www.egyptiantextilemagazine.com/topicDetails.aspx? CatID= 3 \&topID $=208$.

26-https://www.iravin.com/blog/\%D9\%A9-\%D8\%A7\%D9\%86\%D9 \%88\%D8\%A7\%D8\%B9-\%D9\%85\%D9\%86-

\%D8\%A7\%D9\%84\%D8\%AF\%D9\%8A\%D9\%86\% D9\%85\%D9\%88-\%D8\%AA\%D8\%A7\%D8\%B1\%D9\%8A\%D8\%AE\%D8\%A7\%D9\%84\%D8 \%AF\%D9\%8A\% D9\%86\%D9\%85history-denim-9-/different.

27-https://en.wikipedia.org/wiki/Spandex.

28-https://en.wikipedia.org/wiki/Denim.

29-U Sayed, etal(2001),Colourage, vol. 118, no. 2, p. 15. 


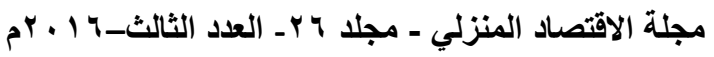

\title{
Enrichment of Functional andAesthetic Value for Women's Evening Wear by Using Denim Fabric Blended with Lycra
}

\author{
Rania Mohamed Ali Mahmoud \\ Doctor in Department of Home Economics, Faculty of Specific Education, Benha University
}

Abstract:

The research aims to use denim fabric blended with lycrain the rate of $4 \%$ to enrich functionaland aesthetic value for women's evening wear, and to determine the benefit of using denim fabric blended with lycra, and the use of different jeans designs for women's evening wear designs proposed by the innovative, functional and aesthetic side.

The researcher identified four types of (accessories, auxiliary fabrics, drawings and coloring) used with denim fabric blended with lycrain the rate of $4 \%$, and the preparation of twelve proposed designs for women's evening wear .

These proposed designs were evaluated by two sides (specialists and beneficiaries), the best designs were suggestedin achieving aspects of the assessment (as a whole) of the design,according to the opinions of specialistsdesign $(2,3,6,7,8)$, and, according to the opinions of beneficiaries design $(7,8)$.the best designs proposed for denim fabric blended with lycrawith (auxiliary fabrics),next denim fabric blended with lycrawith (accessories),next denim fabric blended with lycrawith (drawings and coloring)according to the opinions of both specialists and beneficiaries. and the best axes achieving the innovative aspect, next achieving the functional aspect, next achieving the aesthetic aspectaccording to the opinions of specialists, while the best axesachieving the functional aspect, next achieving the innovative aspect, next achieving the aesthetic aspect according to the opinions of beneficiaries.and that there is a correlation between the order of both (specialists and beneficiaries) of the proposed designs in the light of the evaluation aspects (as a whole),the proposed denim fabric blended with lycrawith (accessories, auxiliary fabrics, drawings and coloring), and evaluation axes,it is a positive relationship, that is, there is a consensus between the evaluation in terms of scientific and practical. 


$$
\text { مجلة الاقتصاد المنزلي - مجلد ج r ـ العدد الثالث-؟ } 1 \text { ـ بم }
$$

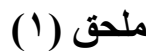

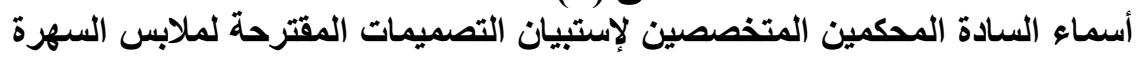

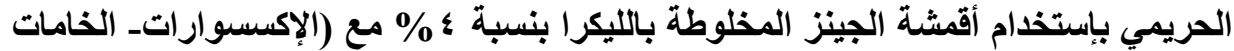
المساعدة- الرسومات والتلوين)

\begin{tabular}{|c|c|c|}
\hline التخصص و الوظيفة & الاسم & $p$ \\
\hline 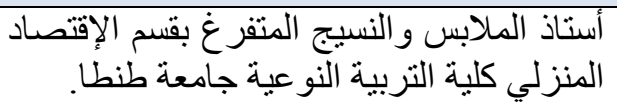 & أ.د / عادل جمال الدين الهنداوى & 1 \\
\hline 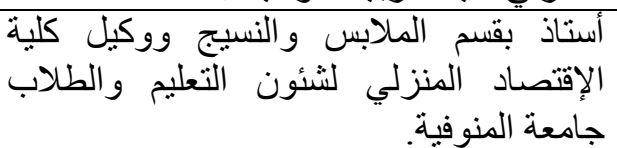 & أ.د / إسلام حسين عبدالمنعم & $r$ \\
\hline 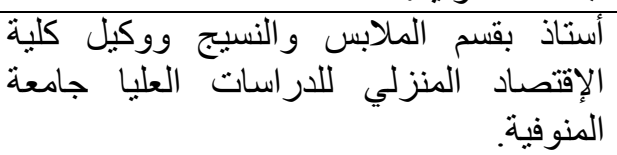 & أ.د / إيهاب أحمد النعمان & $r$ \\
\hline بكلية الإقتصناد التصنيم ورئبس قامعة المنلابس و النسيجة & أ.د /إيهاب فاضل أبوموسى & $\varepsilon$ \\
\hline أسنتاذ بقسم الملابس و النسيج كلية الإقتصاد & أ.د / علا يوسف عحمد عبداللاه & 0 \\
\hline 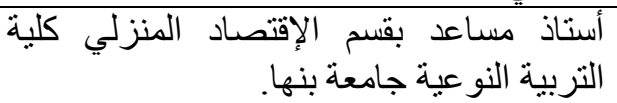 & أ.م.د/ منى عبدالهادى محمد شاهين & 7 \\
\hline أستاذ مساعد بقسم الإقتصاد المنزلي كلية & أ.م.د/ رانيا محمد حمودة & $\mathrm{V}$ \\
\hline المنزلي جامعة المنوفية. و النسيج كلية الإقتصاد & د/ لحمل عبد الحميد حجاج & $\Lambda$ \\
\hline كلية التربية النو عية جامعة الاسكند الإقدرية. & د/ رحاب طه حسين شر ادح & 9 \\
\hline كلية التربية النو عية جامعة الاسكندرية الإقتصاد المنزلية & د/ السيدة خيري عفيفي النحراوي & 1. \\
\hline 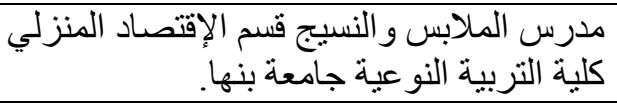 & د/ نجلاء فوزي محمود فحما & 11 \\
\hline كلية التربية النو عية جامعة بنها. الإقتصاد المنزلي & د/ نيفين عبد الوكيل عطا ابراهيم & Ir \\
\hline كلية التربية النو عية جامعة بنها. الإقتصاد المنزلية & د/ مروة حسن محمد عبد الباسط & 14 \\
\hline
\end{tabular}




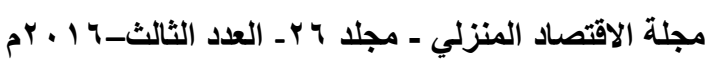

ملقى (r)

جامعة بنها

كلية التربية النوعية النية

قسم الإقتصاد المنزلي

إستبيان تحكيم للتصميمات المقترحة لملابس السهرة الحريمي بإستخدام أقمشة الجينز المخلوطة بالليكرا بنسبة ؛ \% مع (الإكسواراتـ الخامات المساعدة. الرسومات والتلوين)

موجه إلى

ـ الأساتذة الأكاديميون المتخصصون في مجال الملابس والنسيج بالجامعات المصرية.

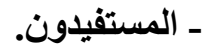

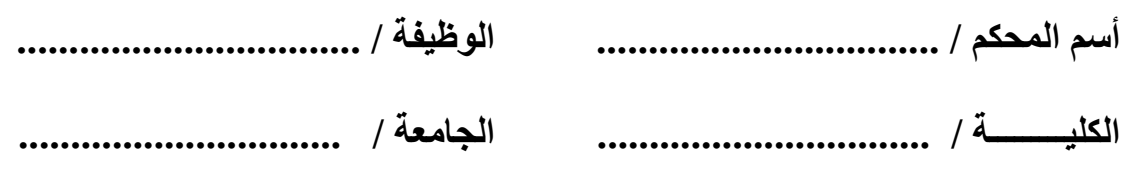

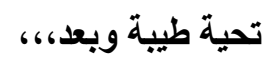

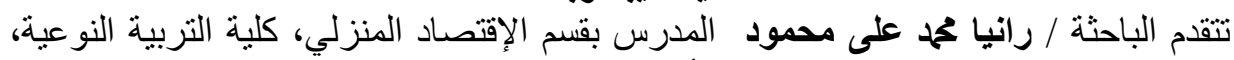

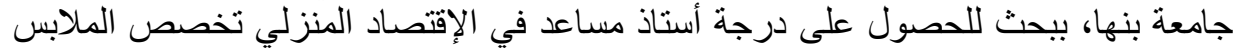

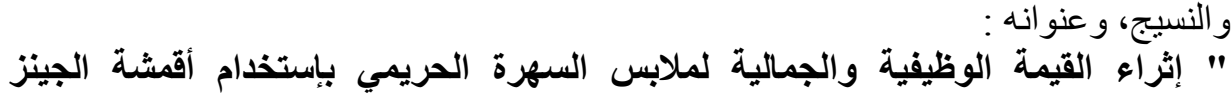
المخلوطة بالليكرا".

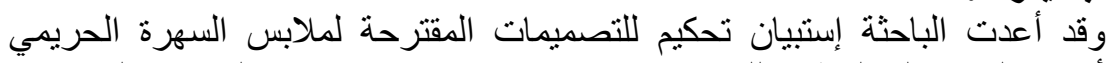

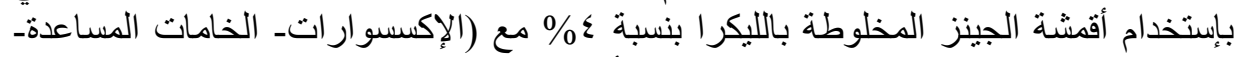

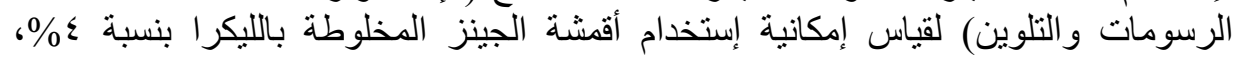

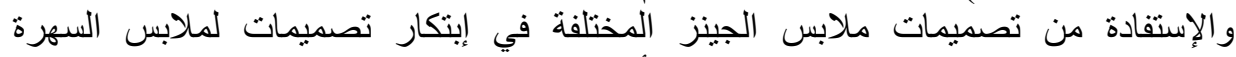

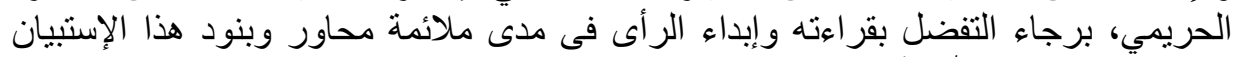

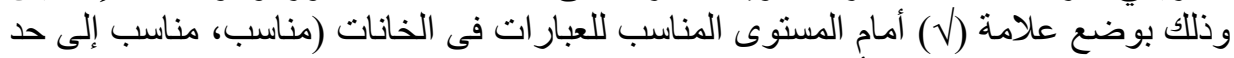

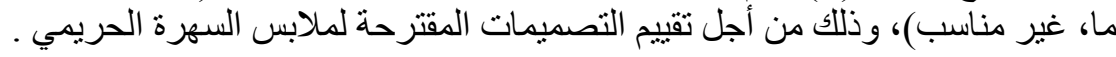
ونشكركم على حسن تعاونكم لاعم العلم فى رفع شأن صناعتنا المصرية.

الباحثة 
مجلة الاقتصاد المنزلي - مجلد ج r ـ العدد الثالث_r 1 • r م

\begin{tabular}{|c|c|c|c|c|c|c|c|c|c|c|c|c|c|}
\hline \multicolumn{12}{|c|}{ 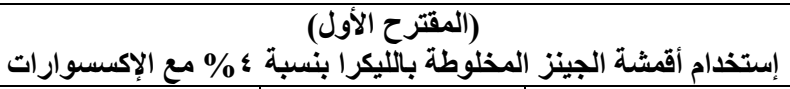 } & \multirow{2}{*}{\multicolumn{2}{|c|}{ المحاور }} \\
\hline \multicolumn{4}{|c|}{ غير مناسب } & \multicolumn{4}{|c|}{ مناسب إلى حد ما } & \multicolumn{4}{|c|}{ مناسب } & & \\
\hline$\varepsilon$ & $r$ & $r$ & 1 & $\varepsilon$ & $r$ & $r$ & 1 & $\varepsilon$ & $r$ & $r$ & 1 & \multicolumn{2}{|l|}{ رقم التصميم } \\
\hline \multicolumn{14}{|c|}{ المحور الأول: الجانب الإبتكاري } \\
\hline & & & & & & & & & & & & 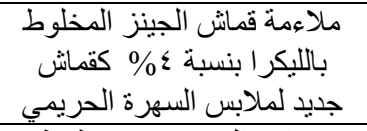 & 1 \\
\hline & & & & & & & & & & & & ينو افق التصميم مع خطوطنة المدينة. & r \\
\hline & & & & & & & & & & & & بساعد التصميم على التجديد & $r$ \\
\hline & & & & & & & & & & & & التصميمات لها أفكار مبتكرة. & $\varepsilon$ \\
\hline & & & & & & & & & & & & 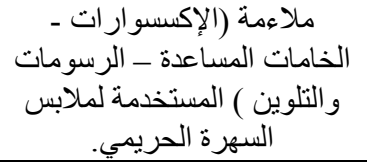 & $\bullet$ \\
\hline \multicolumn{14}{|c|}{ المحور الثاني: الجانب الوظيفي } \\
\hline & & & & & & & & & & & & يناسب التصميم المر أة من سن (1) & 1 \\
\hline & & & & & & & & & & & & التصميم يحقق الراحة. & $r$ \\
\hline & & & & & & & & & & & & يتميز التصميم بسهولة الإرتداء. & $r$ \\
\hline & & & & & & & & & & & & يساعد التصميم على سهولة & $\varepsilon$ \\
\hline & & & & & & & & & & & & 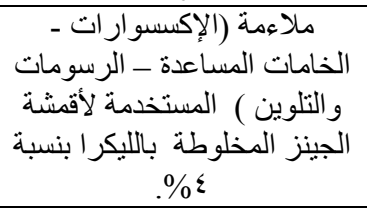 & • \\
\hline \multicolumn{14}{|c|}{ المحور الثالث: الجاتب الجمالي } \\
\hline & & & & & & & & & & & & الشكل العام للتصميح. & 1 \\
\hline & & & & & & & & & & & & النسبة و التناسب بين أجز اء & r \\
\hline & & & & & & & & & & & & المختلفة باللمسيمة الجمالية ملابس الملابنز & r \\
\hline & & & & & & & & & & & & تتاست الألوان في التصميح. & $\varepsilon$ \\
\hline & & & & & & & & & & & & ملاءمة التصميم الزخرفي مع التصئي. & $\bullet$ \\
\hline
\end{tabular}


مجلة الاقتصاد المنزلي - مجلد צ r ـ العدد الثالث-7 1 ـ ب م

\begin{tabular}{|c|c|c|c|c|c|c|c|c|c|c|c|c|c|}
\hline \multicolumn{12}{|c|}{ 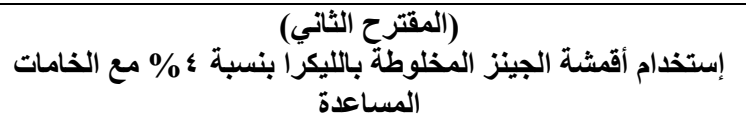 } & \multirow{2}{*}{\multicolumn{2}{|c|}{ 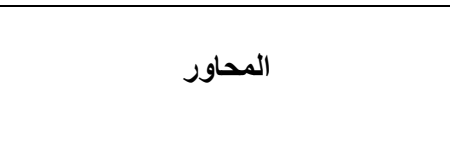 }} \\
\hline \multicolumn{4}{|c|}{ غير مناسب } & \multicolumn{4}{|c|}{ مناسب إلى حـ ما } & \multicolumn{4}{|c|}{ مناسب } & & \\
\hline$\Lambda$ & $\mathrm{V}$ & 7 & 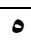 & $\Lambda$ & $\mathrm{V}$ & 7 & 0 & $\Lambda$ & $\mathrm{V}$ & 7 & 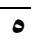 & رقم التصميم & \\
\hline \multicolumn{14}{|c|}{ المحور الأول: الجاتب الإبتكاري } \\
\hline & & & & & & & & & & & & 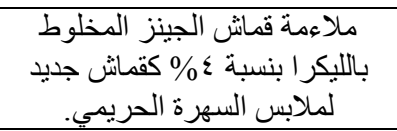 & 1 \\
\hline & & & & & & & & & & & & يتو افق التصميم مع خطوط الموضة & r \\
\hline & & & & & & & & & & & & 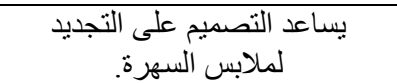 & r \\
\hline & & & & & & & & & & & & التصميمات لها أفكار مبتكرة. & $\varepsilon$ \\
\hline & & & & & & & & & & & & 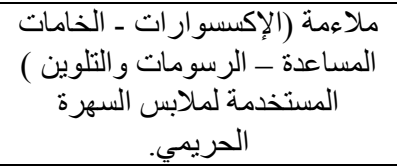 & $\bullet$ \\
\hline \multicolumn{14}{|c|}{ المحور الثاني: الجانب الوظيفي } \\
\hline & & & & & & & & & & & & 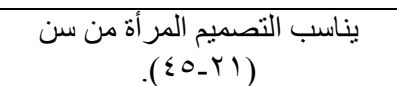 & 1 \\
\hline & & & & & & & & & & & & التصميم يحقق الراحة. & $r$ \\
\hline & & & & & & & & & & & & يتميز التصميم بسهولة الإرتداء. & $r$ \\
\hline & & & & & & & & & & & & يساعد التصميم على سهولة & $\varepsilon$ \\
\hline & & & & & & & & & & & & 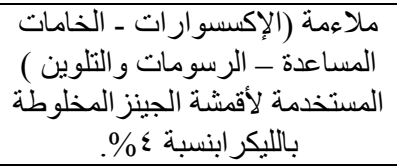 & $\bullet$ \\
\hline \multicolumn{14}{|c|}{ المحور الثالث: الجاتب الجمالي } \\
\hline & & & & & & & & & & & & الثكل العام للتصميم. & 1 \\
\hline & & & & & & & & & & & & النسبة و التناسب بين أجزاء & r \\
\hline & & & & & & & & & & & & المختلفة باللمسيزة الجمالية ملابس الجينز السيس & r \\
\hline & & & & & & & & & & & & تناسق الألوان في التصميم. & $\varepsilon$ \\
\hline & & & & & & & & & & & & ملاءمة التصميم الزّخرفي مع التصائي. & 0 \\
\hline
\end{tabular}




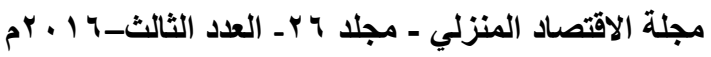

\begin{tabular}{|c|c|c|c|c|c|c|c|c|c|c|c|c|c|}
\hline & تلتوين & \% مع & $\ddot{a}$ & ( & ل & لخلوط & ينز & ثُة الج & ثدام أقق & & & المحاور & \\
\hline & ناسب & غير & & & لي إلى & ناسب ن ن ن ن ن ن & & & اسبب & & & & \\
\hline Tr & 11 & 1. & 9 & IT & 11 & 1. & 9 & TY & 11 & 1. & 9 & رقم التصميم & \\
\hline & & & & & & 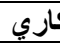 & 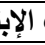 & الجاتن & 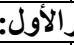 & 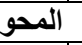 & & & \\
\hline & & & & & & & & & & & & 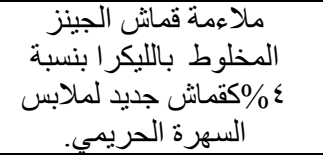 & \\
\hline & & & & & & & & & & & & 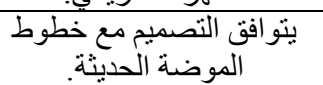 & r \\
\hline & & & & & & & & & & & & يساعد التصميم على التجديد. & $r$ \\
\hline & & & & & & & & & & & & التصميمات لها أفكار & $\varepsilon$ \\
\hline & & & & & & & & & & & & 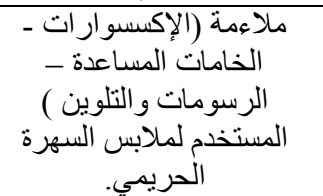 & \\
\hline & & & & & & ليفي ل ليفي & 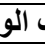 & 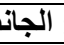 & 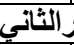 & المحو - ل المو & & & \\
\hline & & & & & & & & & & & & يناسب التصميح المر أة من & 1 \\
\hline & & & & & & & & & & & & التصميم يحقق الراحة. & r \\
\hline & & & & & & & & & & & & يتميز التصميم بسهولة & $r$ \\
\hline & & & & & & & & & & & & يساعد التصميمة على سهولة & $\varepsilon$ \\
\hline & & & & & & & & & & & & 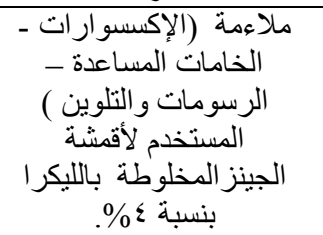 & 0 \\
\hline & & & & & & & 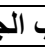 & 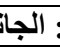 & 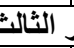 & 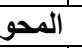 & & & \\
\hline & & & & & & & & & & & & الثكل العام للتصمير. & 1 \\
\hline & & & & & & & & & & & & النسبة والتتناسب بين أجزاء & r \\
\hline & & & & & & & & & & & & 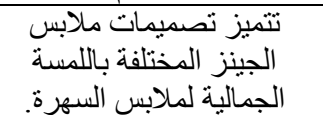 & r \\
\hline & & & & & & & & & & & & تناسق الَالَّوان في التصميح. & $\varepsilon$ \\
\hline & & & & & & & & & & & & ملاءمة التصميميم الزيأزخي. & ๑ \\
\hline
\end{tabular}

